\title{
Resource Handbook for Low-Income Residential Retrofits
}
J. W. Callaway
D. L. Ivey
D. L. Brenchley
S. A. Smith
L. J. Davis
E. J. Westergard

April 1987

Prepared for the U.S. Department of Energy under Contract DE-AC06-76RLO 1830

Pacific Northwest Laboratory

Operated for the U.S. Department of Energy

by Battelle Memorial Institute 


\title{
DISCLAIMER
}

This report was prepared as an account of work sponsored by an agency of the United States Government. Neither the United States Government nor any agency thereof, nor Battelle Memorial Institute, nor any of their employees, makes any warranty, expressed or implied, or assumes any legal liability or responsibility for the accuracy, completeness, or usefulness of any information, apparatus, product, or process disclosed, or represents that its use would not infringe privately owned rights. Reference herein to any specific commercial product, process, or service by trade name, trademark, manufacturer, or otherwise, does not necessarily constitute or imply its endorsement, recommendation, or favoring by the United States Government of any agency thereof, or Battelle Memorial Institute. The views and opinions of authors expressed herein do not necessarly state or reflect those of the United States Government or any agency thereof, or Battelle Memorial Institute.

\author{
PACIFIC NORTHWEST LABORATORY \\ operated by \\ BATTELLE MEMORIAL INSTITUTE \\ for the \\ UNITED STATES DEPARTMENT OF ENERGY \\ under Contract DE-AC06-76RLO 1830
}


RESOURCE HANDBOOK FOR LOW-INCOME RESIDENTIAL RETROFITS

J. W. Callaway, Project Manager

D. L. Brenchley

L. J. Davis

D. L. Ivey

S. A. Smith

E. J. Westergard

April 1987

Prepared for the U.S. Department of Energy

under Contract DE-ACO6-76RLO 1830

Pacific Northwest Laboratory

Richland, Washington 99352 
-

-

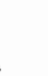




\section{SUMMARY}

Pacific Northwest Laboratory (PNL) prepared this Resource Handbook on LowIncome Residential Retrofits for the Office of State and Local Assistance Programs of the U.S. Department of Energy (DOE). The purpose of the handbook is to provide technical assistance to state grantees participating in the Partnerships in Low-Income Residential Retrofit (PILIRR) Program. The grantees, in turn, may use the materials with partners in implementing their projects.

PILIRR is a demonstration program aimed at identifying innovative, successful approaches to developing public and private support for weatherization of low-income households. The program reflects the basic concept that responsibility for financial support for conservation activities such as low-income residential retrofitting is likely to gradually shift from the DOE to the states and the private sector.

In preparing the handbook, PNL staff surveyed over 50 programs that provide assistance to low-income residents. The survey provided information on factors that contribute to successful programs. PNL also studied the winning PILIRR proposals (from the states of Florida, Iowa, Kentucky, Oklahoma and Washington) and identified the approaches proposed and the type of information that would be most helpful in implementing these approaches. These findings shaped the format and content of the resource handbook. The first section describes key factors affecting participation in a low-income residential retrofit program. Those factors include:

Developing partnerships. Forming partnerships or coalitions among several organizations or among organizations and local government is beneficial to a successful PILIRR program. In this way it is possible to achieve benefits that a single organization could not provide.

Marketing strategies. Systematic organization and direction of activities are required to accomplish measurable and realistic goals for generating support.

Promotion. Effective ways must be developed for targeting participants and obtaining support for low-income programs.

Utility roles. The reliance on utility participation is universal but it is important to realistically gauge the type and level of support available.

Problems and opportunities in retrofitting rental housing. Rental housing represents a substantial portion of the low-income households. However, until now this segment of the housing sector has been largely overlooked in energy conservation efforts. Landlord participation in retrofit programs needs to be improved in order to include these participants in low-income programs.

The second section of the handbook focuses on the main categories of nonfederal low-income residential retrofitting: 
Utility programs. Fifteen utility programs were reviewed. Their services include home energy audits and antifiltration measures such as weatherstripping, caulking, and insulation.

Nonprofit programs. Six nonprofit organizations were identified that have undertaken programs to help low-income residents weatherize their homes. These organizations primarily offered strictly low-cost measures that reduce air-infiltration.

State programs. Nine state programs and one city program were identified as being designed to deliver weatherization services to low-income households without the use of federal funds. These programs involved the cooperation and assistance of nonprofit organizations, utilities, and other state offices.

Business spin-offs. Nine organizations have used business spin-offs to support low-income conservation efforts. The types of spin-offs ranged from the fabrication of wooden windows to a thrift shop where elderly residents of a community donate time and unwanted possessions to a "worthwhile cause." Some businesses produced items used only in the weatherization progran whereas others marketed their products to individuals and businesses in the community.

While the circumstances associated with each nonfederal program are somewhat unique, several obvious patterns of experience provided some insight into essential program characteristics. The factors that appear to contribute to the success and sustainability of programs include having a motivated director, developing an effective network, and providing incentives to participation. 


\section{CONTENTS}

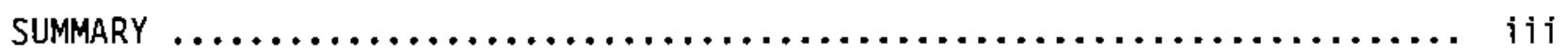

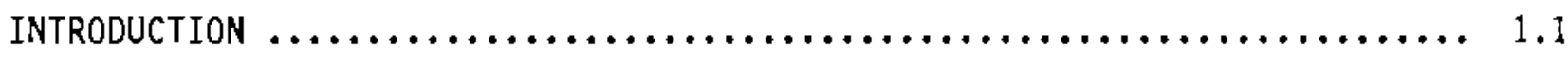

BACKGROUND $\ldots \ldots \ldots \ldots \ldots \ldots \ldots \ldots \ldots \ldots \ldots \ldots \ldots \ldots \ldots \ldots \ldots, 1.2$

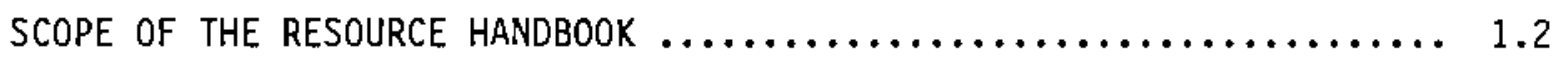

Survey of Existing Programs $\ldots \ldots \ldots \ldots \ldots \ldots \ldots \ldots \ldots \ldots, 1.2$

Supplemental Information $\ldots \ldots \ldots \ldots \ldots \ldots \ldots \ldots \ldots \ldots \ldots \ldots, 1.3$

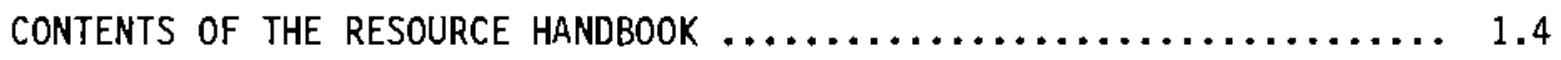

Factors Affecting Participation $\ldots \ldots \ldots \ldots \ldots \ldots \ldots \ldots \ldots \ldots \ldots \ldots \ldots, 1.4$

Existing Nonfederal Low-Income Retrofitting $\ldots \ldots \ldots \ldots \ldots \ldots .1 .5$

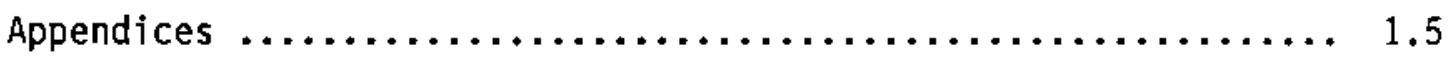

I. FACTORS AFFECTING PARTICIPATION

DEVELOPING PARTNERSHIPS $\ldots \ldots \ldots \ldots \ldots \ldots \ldots \ldots \ldots \ldots \ldots \ldots \ldots \ldots \ldots, 2.1$

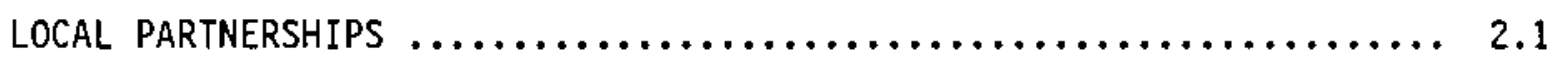

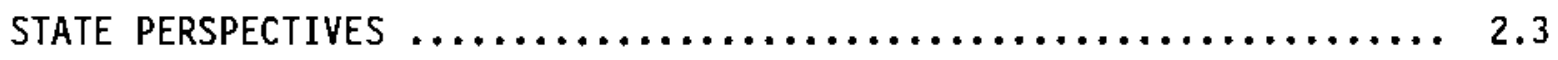

MARKETING AND PROMOTION OF LOW-INCOME RESIDENTIAL RETROFITTING $\ldots \ldots \ldots \ldots . .1$

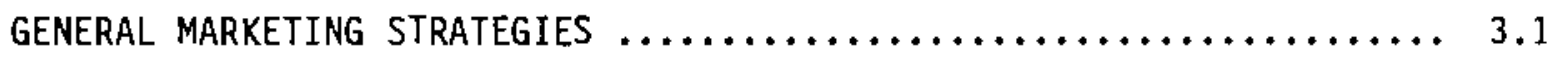

Marketing Efforts by Nonprofit Organizations $\ldots \ldots \ldots \ldots \ldots \ldots, 3.1$

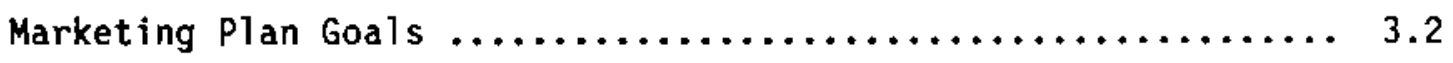

Features of a Marketing Plan $\ldots \ldots \ldots \ldots \ldots \ldots \ldots \ldots \ldots \ldots \ldots, 3.4$

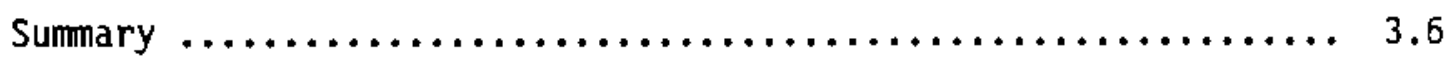

PROMOTING LOW-INCOME RESIDENTIAL RETROFITTING $\ldots \ldots \ldots \ldots \ldots \ldots \ldots . .6$

Targeting Low-Income Weatherization Marketing Efforts $\ldots \ldots \ldots \ldots .6$

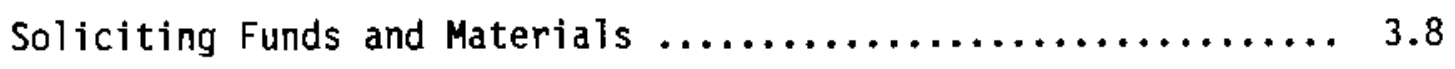

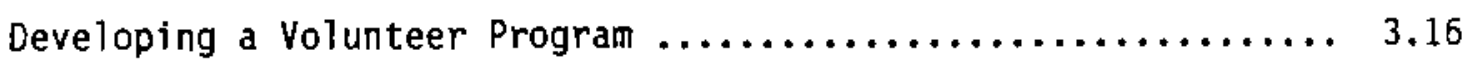


UTILITY ROLES IN CONSERVATION AND LOW-INCOME RESIDENTIAL RETROFITTING $\ldots . .4 .1$

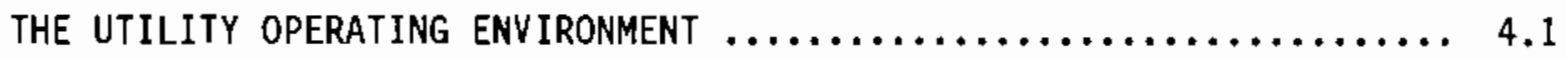
REASONS WHY UTILITIES PARTICIPATE IN CONSERVATION $\ldots \ldots \ldots \ldots \ldots \ldots, 4.2$

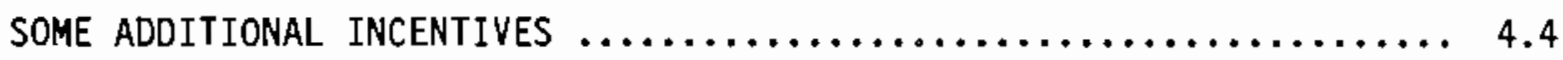
WHAT ARE SOME OF THE DISINCENTIVES TO UTILITY PARTICIPATION? $\ldots \ldots \ldots \quad 4.5$ PROBLEMS AND OPPORTUNITIES IN RENTAL HOUSING RETROFITTING $\ldots \ldots \ldots \ldots \ldots \ldots . . .$. OWNERS' DECISION PROCESS FOR CONSERVATION INVESTMENTS $\ldots \ldots \ldots \ldots \ldots .5 .3$

Reasons for Making and Not Making Conservation Improvements..... 5.3 Decision Criteria Used for Conservation Improvements $\ldots \ldots \ldots \ldots, 5.6$ Source of Funds for Conservation Improvements $\ldots \ldots \ldots \ldots \ldots \ldots, 5.7$

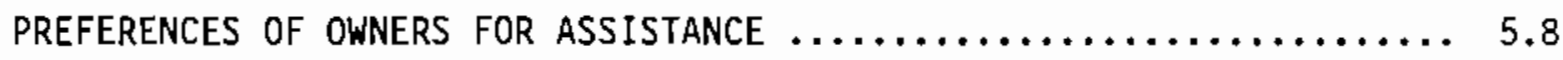
TECHNIQUES FOR CONVEYING INFORMATION TO OWNERS $\ldots \ldots \ldots \ldots \ldots \ldots \ldots .5 .9$

II. SURVEY OF EXISTING NONFEDERAL RESIDENTIAL RETROFIT PROGRAMS EXISTING NONFEDERAL LOW-INCOME RESIDENTIAL RETROFITTING $\ldots \ldots \ldots \ldots \ldots \ldots \ldots, 6.1$

UTILITY PROGRAMS $\ldots \ldots \ldots \ldots \ldots \ldots \ldots \ldots \ldots \ldots \ldots \ldots \ldots \ldots \ldots \ldots \ldots \ldots, 6.1$

Where Does the Money Come From? $\ldots \ldots \ldots \ldots \ldots \ldots \ldots \ldots \ldots \ldots, 6.1$

Who's Eligible for Utility Programs? $\ldots \ldots \ldots \ldots \ldots \ldots \ldots \ldots \ldots .6 .5$

What Sort of Networking/Partnerships Exist? .............. 6.5

Utilities and Social Service Agencies $\ldots \ldots \ldots \ldots \ldots \ldots \ldots \ldots, 6.6$

Partnerships Between Utilities and State Offices $\ldots \ldots \ldots \ldots \ldots, 6.6$

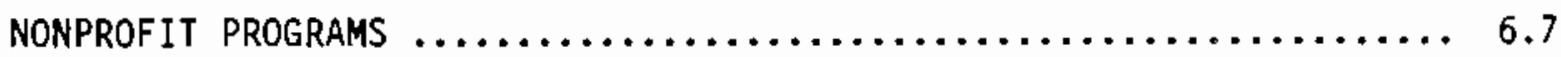

Typical Services Offered by Nonprofit Organizations $\ldots \ldots \ldots \ldots, 6.7$

Why Do Nonprofits Become Involved in Low-Income

Weatherization? ...................................... 6.7

Examples of Programs Supported Mainly by Nonprofits $\ldots \ldots \ldots \ldots .6 .8$

How are Nonprofit Groups Normally Involved? .............. 6.8

What Role Do Large Nonprofit Organizations Play? ........... 6.8 


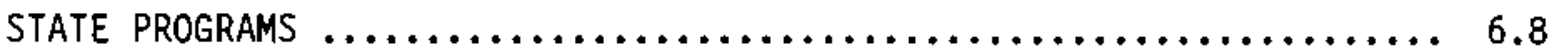

History of State Weatherization Involvements $\ldots \ldots \ldots \ldots \ldots \ldots, 6.9$

What State Efforts Go Beyond WAP and LIHEAP? ............... 6.9

The States' Role in Partnerships ........................ 6.10

Services Offered by State Programs $\ldots \ldots \ldots \ldots \ldots \ldots \ldots \ldots \ldots \ldots .6 .10$

State Coordination with Social Service Agencies ............. 6.10

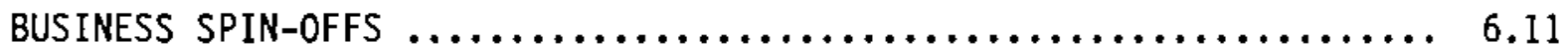

Where Do The Profits Go? ............................ 6.12

How are Spin-0ffs Started? $\ldots \ldots \ldots \ldots \ldots \ldots \ldots \ldots, \ldots \ldots \ldots, 6.12$

What Administers Should Know About Social Service Agency

Attitudes Toward Spin-0ffs ............................ 6.16

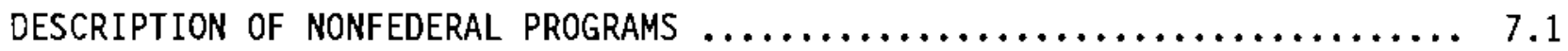

WHAT MAKES RESIDENTIAL RETROFIT PROGRAMS WORK? $\ldots \ldots \ldots \ldots \ldots \ldots \ldots, 7.1$

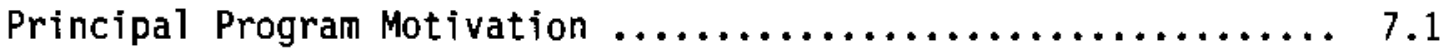

Financial Support $\ldots \ldots \ldots \ldots \ldots \ldots \ldots \ldots \ldots \ldots \ldots \ldots \ldots \ldots, \quad 7.5$

Nonfinancial Support $\ldots \ldots \ldots \ldots \ldots \ldots \ldots \ldots \ldots \ldots \ldots \ldots, 7.6$

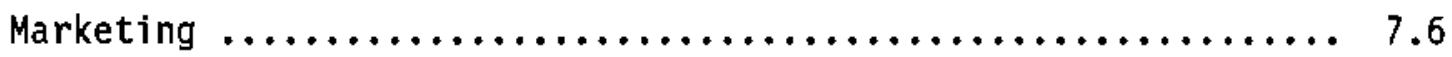

What Factors Are Related to Successful Retrofitting

Efforts? .......................................... 7.7

Summary $\ldots \ldots \ldots \ldots \ldots \ldots \ldots \ldots \ldots \ldots \ldots \ldots \ldots \ldots \ldots \ldots \ldots \ldots \ldots, 7.10$

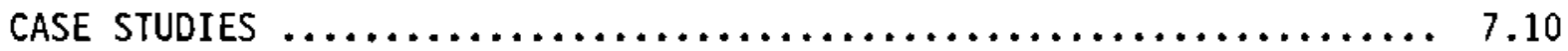

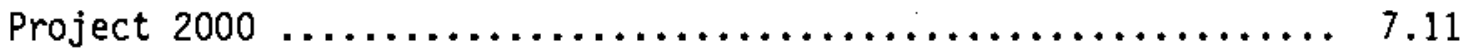

Blue Mountain Economic Development Council $\ldots \ldots \ldots \ldots \ldots \ldots \ldots .7 .14$

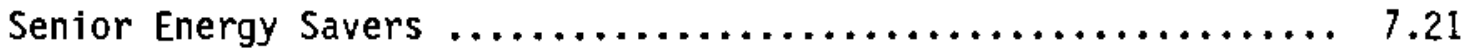

Centralia Area Energy Assistance Program $\ldots \ldots \ldots \ldots \ldots \ldots \ldots . . .21$

Capacity Building for Energy Conservation $\ldots \ldots \ldots \ldots \ldots \ldots \ldots, 7.24$ 


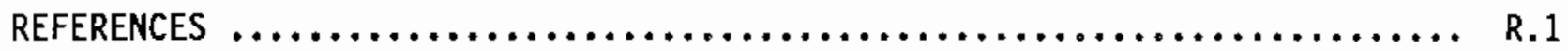
APPENDIX A: NONFEDERAL PROGRAMS IDENTIFIED IN SURVEY $\ldots \ldots \ldots \ldots \ldots \ldots \ldots \ldots$ APPENDIX B: BIBLIOGRAPHY $\ldots \ldots \ldots \ldots \ldots \ldots \ldots \ldots \ldots \ldots \ldots \ldots \ldots \ldots \ldots \ldots \ldots$ APPENDIX $c:$ STATE WEATHERIZATION OFFICES $\ldots \ldots \ldots \ldots \ldots \ldots \ldots \ldots \ldots \ldots \ldots . . \ldots$ 
I. FACTORS AFFECTING PARTICIPATION 
The topics included in the first section of the handbook were selected because they represent related elements common to most of the proposed state programs to be developed and implemented through the PILIRR grants. The commentaries that have been provided on these topics are not intended to reflect the full extent of current knowledge, but to serve as summaries and "jumping off" points for further discussions at the PILIRR workshop. 


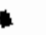

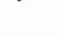




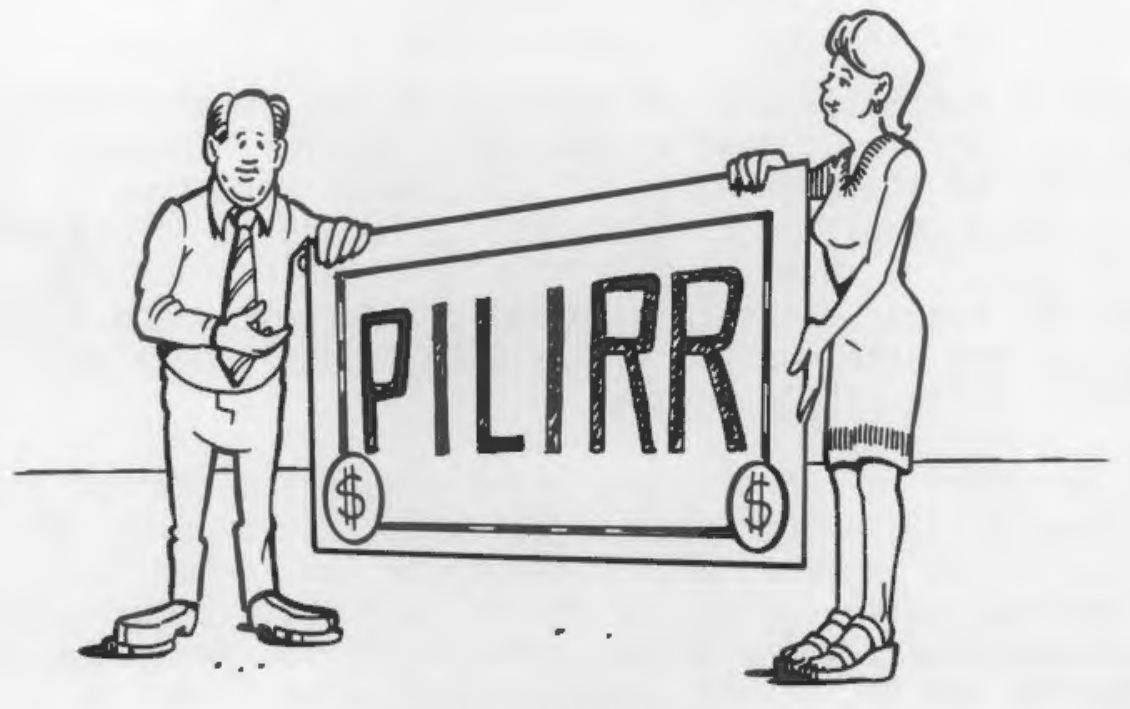

INTRODUCTION

In February 1986, the U.S. Department of Energy (DOE), Office of State and Local Assistance Programs, issued a Request for Proposals for states to develop innovative demonstration programs for leveraging nonfederal dollars to supplement current federal low-income weatherization efforts. Florida, Iowa, Kentucky, Oklahoma and Washington were awarded grants to participate in the demonstration program, entitled the Partnerships in Low-Income Residential Retrofit (PILIRR) Program. The demonstration effort has several purposes:

1. to determine the degree to which nonfederal public and private money and in-kind support can be generated by states to, successfully retrofit the residences of low-income households, in accordance with criteria of the federal government's Weatherization Assistance Program (WAP)

2. to test innovative ways for states to leverage public and private dollars for low-income weatherization

3. to encourage the development of partnerships among the states and other public and private entities to address the low-income household weatherization needs that are not adequately met by current federal programs for weatherization assistance.

The PILIRR program reflects the basic concept that responsibility for financial support for conservation activities such as low-income residential retrofitting is likely to gradually shift from the DOE and other federal agencies to the states and the private sector. As its role changes, DOE's present strategies also call for an active effort to support conservation through technical assistance, information transfer and strategic support of innovative nonfederal conservation efforts. In the PILIRR program, the DOE will be testing, under a specific setting, its ability to provide this type of support. 
To assist in accomplishing the purposes of the demonstration effort, the DOE directed its Pacific Northwest Laboratory (PNL) 1) to prepare resource materials for use by state grantees, 2) to conduct workshops to initiate and facilitate the conduct of the projects and 3 ) to assist in evaluating the demonstration projects. A major objective of the first workshop, for which this handbook was prepared, is to help build information and support networks among the states and other partners that will enhance their ability to accomplish the goals of the PILIRR program.

PNL was directed to identify and briefly describe current efforts by states and other public and private organizations (including those supported by federal grants) to improve the efficiency of low-income residences. By examining these current programs, PNL hopes to provide some insight, ideas, and guidance on innovative weatherization efforts for low-income households. In addition, the DOE and PNL jointly identified several topics related to the problems of low-income residential retrofitting by public and private entities other than the federal government. These topics were addressed as well, and this resource handbook reports those efforts.

The handbook is intended for use by the state PILIRR grantees and their partners in this effort. The emphasis is on how to promote successful lowincome residential retrofit programs through partnershipping, promoting third-party financing, and resource leveraging. This material may also be useful to any public or private group that has an interest in promoting or is currently involved in energy-efficiency improvements of low-income homes. It should be a good starting point for those interested in devising new ways to supplement the federal WAP program to solve the problems of energy-efficient housing faced by low-income households.

\section{SCOPE OF THE RESOURCE HANDBOOK}

The objective of this handbook is to concisely provide information that may be useful to the PILIRR grantees as they refine their programs and begin to implement them. Two primary sets of activities were undertaken in preparing this handbook: a survey of existing nonfederal low-income weatherization programs and a gathering of supplemental information that may be helpful to PILIRR grantees.

\section{Survey of Existing Programs}

The survey was designed to collect information about existing weatherization activities that are supported by nonfederal dollars. PNL identified a wide variety of programs to improve the energy efficiency of low-income homes. Many of those programs use innovative ways to attract support and to ensure sustainability. 
Because no central source of information is available on low-income weatherization programs that receive support from nonprofit or private sources, the State Energy Offices were contacted as a first step. These offices are frequently involved in administering the WAP, and therefore are often good sources of information about low-income weatherization programs in the state. The offices provided names of utility programs, community action agency business spin-offs, and nonprofit programs. In addition, several nonprofit groups were contacted, including United Way, Green Thumb, Habitat for Humanity, National Urban League, the Alliance to Save Energy, and the National Association of Retired Persons. PNL interviewed the personnel of the organizations responsible for the programs to obtain information about the inception, implementation and status of these programs. This approach provided information about a substantial and diverse number of programs.

\section{Supplemental Information}

The PILIRR proposals from the five states were closely examined to understand the proposed roles of the states and partner organizations in the program, and to identify the information that would be most useful to them. Three primary types of state roles were identified:

- policy/regulation-making for, and evaluation of, the demonstration program

- program administration

- establishing the institutional framework that would permit the partnership aspects of the programs to function--for example, setting up contract mechanisms; identifying or creating intermediary organizations; identifying intra-state, state-local and public-private sector coordination responsibilities and procedures; and preparing fundraising and promotional strategies.

Several types of roles for partnership organizations were also noted:

- administration of leveraged funds

- processing applications and contracting for, conducting, and/or certifying the retrofits

- ensuring sustainability of programs through fundraising, successful recruitment of participants, materials, labor, and volunteers.

Based on these roles, information in the following areas appeared to be useful and therefore was provided: development and operation of partnerships, promotion/marketing of support and participation, utility roles, and considerations for rental housing retrofitting. 


\section{CONTENTS OF THE RESOURCE HANDBOOK}

The main text of the handbook is presented in two sections, each containing several chapters. The first section, "Factors Affecting Participation," discusses partnershipping, promotion/marketing of support and participation, utility roles, and considerations for rental housing retrofitting. The second section, "Existing Nonfederal Low-Income Residential Retrofitting," describes the categories of nonfederal programs that were identified in the survey. That section also includes a discussion of program features that appear to be related to program success (ability to weatherize low-income homes without federal dollars) and sustainability. Finally, five program case studies are presented in the second section to help illustrate some of the observations made about success and sustainability. Three appendices provide further information in specific areas. The content of the two main sections and the appendices is described in more detail below.

Factors Affecting Participation

The creation and maintenance of partnerships are the first topics in this handbook. Although the notion of developing partnerships at the state and local level is not new, relatively little "when" and "how to" information-from the state perspective--is currently available. Therefore, PNL has drawn heavily upon the proceedings of an all-state conference sponsored by the DOE in September 1985 in Arizona. Community-level partnerships have been addressed more adequately in the literature, and the summarized information is accompanied by lists of suggested resources.

Several of the states plan to rely fairly heavily on strategies to "market" or promote the idea of supporting low-income residential retrofitting. Therefore, the topics of marketing, promotion and fundraising (support) are addressed next. These tools have been covered fairly comprehensively, but always from the perspective of idea or concept promotion, rather than from product marketing.

The key role to be played by utilities in the programs of several of the PILIRR grantees prompted the addition of a chapter to clearly identify the role that utilities have played in conservation and low-income weatherization. With a good understanding of utilities' interest in this conservation activity, state and local partners may be able to develop more substantive support from utilities.

A final participation issue that is covered is energy-efficiency improvements in low-income rental housing. This is a particularly important aspect of residential weatherization activities for the low-income population because substantial numbers of low-income households occupy rented housing, and because various factors have made rental and multifamily housing very difficult to address with traditional conservation programs. Two of the grantee states have chosen to focus on rental housing. While the information on rental housing retrofitting has been included with this in mind, other states and local organizations that tackle this difficult sector most likely will benefit from a better understanding of the barriers to improving the energy efficiency of rental housing. 


\section{Existing Nonfederal Low-Income Residential Retrofitting}

The survey of existing weatherization activities, conducted at the outset of the planning and preparation activities for the workshop, uncovered a wide variety of current low-income residential weatherizing activities that do not rely on federal funding. The survey covered all fifty states, but was not intended to be an exhaustive and complete description of all current low-income residential retrofitting activities. A matrix of program characteristics was created from the survey information and was used to note several prominent program features and trends. The second section also includes case studies of several notable programs as an illustration of the points made in this discussion.

\section{Appendices}

One appendix contains information about the many programs identified in the survey but not included in the case studies. The information is less extensive than that included in the case studies, so contact information is provided for those who wish to learn more about these innovative efforts.

Readers who are interested in pursuing any of the topics discussed in the handbook, or in finding out more about any of the programs that were identified, will find the other appendices useful. One appendix includes a comprehensive bibliography of reports, articles, books and other relevant reading material that addresses the problems of retrofitting low-income homes to make them more energy efficient. The third appendix lists state contacts who can provide information about current state and local activities in low-income residential conservation. 


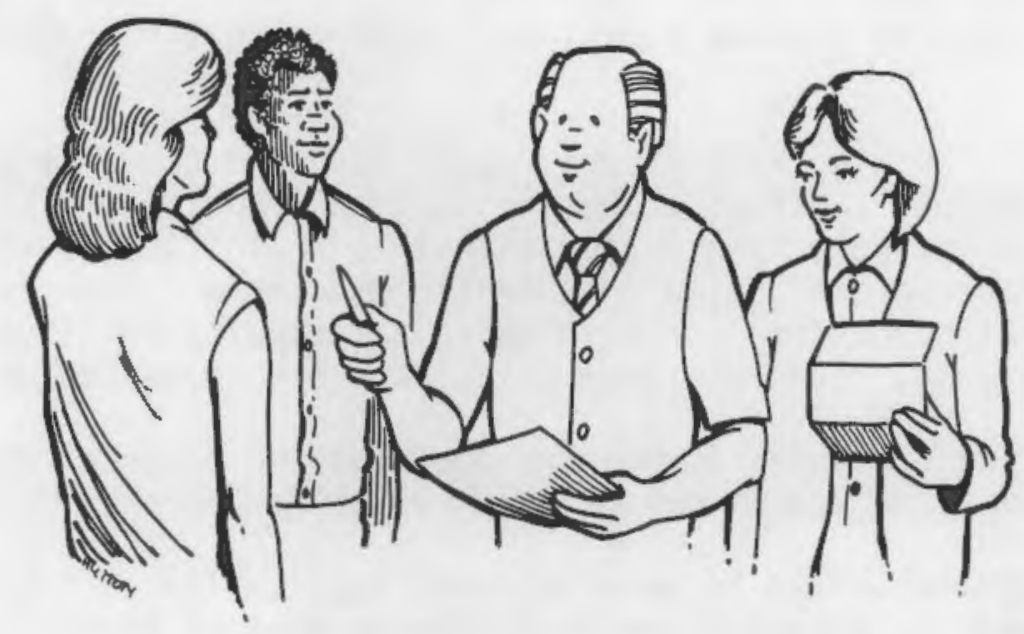

DEVELOPING PARTNERSHIPS

Despite expenditure of billions of dollars for weatherization of lowincome housing, tremendous resources will be needed to improve the energy efficiency of housing that remains untreated. A basic premise of the PILIRR program is that in the face of federal and state budget restrictions, these resources must come from nompublic, as well as public, sources. A key concept that is being tested with PILIRR demonstrations grants is whether public money, manpower, leadership and commitment can be "leveraged" by combining public resources with support from the private and nonprofit sectors of the economy. Forming partnerships with businesses, community organizations, utilities, local governments and others appears to be one way states can effectively accomplish such leveraging.

The development of partnerships or coalitions among several organizations or among several organizations and local government in communities is an increasing way to better provide for the well being of needy citizens. Groups are coming together to talk about, study, and often take action on matters that concern them and that they feel are important to the community. Formal attempts by state and federal governments to forge these linkages have been less common, but now are a rapidly growing activity, particularly at the state level.

In the following subsections, several basic tenets for "partnershipping" are reviewed. First, local and community level arrangements are discussed, followed by a discussion of partnerships from the state perspective.

\section{LOCAL PARTNERSHIPS}

To be most effective in a community, an organization, whether it is private or nonprofit, must realize that there is a certain amount of interdependence between itself and other organizations and different levels of government. Therefore, good sound lines of communication should be maintained. By forming 
partnerships with other organizations and/or local government, a single organization may be able to achieve additional benefits that it could not attain alone.

In the book, Working With Groups, Committees and Communities (Trecher and Trecher 1979), the authors emphasize that an organization must develop certain criteria for selecting projects that it would like to work on with other groups or organizations, and it should develop a community relations policy. A set of guidelines for developing a community relations policy was outlined in the book. Some of these guidelines are presented below:

1. There must be carefully formulated decisions as to which organizations share common goals and therefore should establish formal liaison relations.

2. Serious efforts should be made to avoid duplication of programs and services. Thus, the organization must develop ways of knowing what is already available to people, what is planned by other groups, and what is needed.

3. A community relations policy for any organization must take into account the importance of wise expenditure of community resources in money and talent. There is never enough of either to go around, and communities must carefully use the money and the leadership they have.

4. An organization that develops a community relations policy with other organizations must understand how much autonomy it sacrifices either on temporary projects or on a permanent basis.

If a partnership or coalition is to be formed, all of the members must receive benefits; otherwise, there is little incentive to remain an active member. It is also important to keep in mind the personal goals of other organizations with which the program is linked. The Elders Helping Elders program, sponsored by Northeast Utilities and administered by New Opportunities for Waterburg (a community action agency) in Connecticut, found that although its goals were consistent in terms of providing weatherization assistance to the elderly, the program encountered problems surrounding the personal needs of their individual organizations. For example, the utility had a need to meet the state Public Utility Commission (PUC) regulations, which the other organizations had to take into account. Other weatherization-related groups and organizations found problems as well, so the Governors Energy Advisory Committee was formed. The committee is made up of representatives from utilities, state agencies and community action agencies (CAAs) in Connecticut. The committee meets monthly to discuss issues relating to energy conservation, weatherization, and low-income assistance. According to Toni Hearst of New Opportunities for Waterburg, this committee has worked extremely well to establish a network among the different organizations and a better understanding among members about the needs of each group.

Selected readings that may be useful for learning more about forming partnerships or coalitions within a community include:

- Working with Groups, Committees and Communities by H. B. Trecher and A. R. Trecher (1979) 
- Developing Human Services in New Communities by D. J. Klein (1975)

- How to Get Things Changed: A Handbook for Tackling Community Problems by B. Strauss and M. E. Stowe (1974)

- Livable Cities: A Grass-Roots Guide to Rebuilding Urban America by R. Cassidy (1980).

Also, several organizations and institutions can be helpful in providing more information about urban planning, community development, workshops and training materials for neighborhood groups. Some of these groups are:

- Citizen Involvement Training Project 138 Hasbrouck, Division of Continuing Education University of Massachusetts Amherst, MA 01103

- Institute for Local Self-Reliance 1717 18th St., N.W. Washington, DC 20009

- National Association of Neighborhoods 1612 20th St., N.W. Washington, DC 20009

- National Center for Urban Ethnic Affairs 152116 th St., N.W. Washington, DC 20036

- National Training and Information Center 954 W. Washington Bivd. Chicago, IL 60607.

\section{STATE PERSPECTIVES}

Partnerships among federal and state government agencies and other organizations sharing common interests have occurred to differing degrees in various cases in recent years. However, information on these partnerships and what has made them successful (or not successful) under various conditions is quite limited at the present time. The following information has been drawn primarily from the Brokering Energy Efficiency Partnerships Conference sponsored by the State Energy Conservation Programs/Energy Extension Service (SECP/EES) held on September $10-12,1985$ in Scottsdale, Arizona (McColley 1985). Proceedings from this conference were reviewed in order to summarize state experience to date on the subject of partnerships. Further information on partnerships in general was also obtained from secondary literature sources.

The Brokering Energy Efficiency Partnerships Conference defined partnerships as "establishing and maintaining working relationships between agencies and organizations for common goals" (McColley 1985). Some of the key ideas to keep in mind when developing a partnership are: 
- Partnerships take time to develop.

- They have to be nurtured/maintained once started.

- Personal contact goes a long way. It is important how people treat each other.

Attendees at the conference identified some important steps to follow when developing partnerships (McColley 1985):

- Draft internal goals and approaches. This step involves the state agency taking a close look at the goals that they expect. from the program and the benefits they intend to gain from entering into a partnership with another organization.

- Identify players. Identify potential partner organizations and key persons in those organizations to approach with the partnership idea.

- Make initial contact. Contact with the potential partnership organizations may come in the form of a telephone call, letter, presentation at a group meeting, or a personal visit.

- Follow up initial contact. The best way to follow up initial contact is with a personal visit.

- Identify common interests. Common interests should be expressed and understood because they may be the motivating force behind the development of a partnership.

- Agree to common goals. Once the individual interests of the two organizations are identified, common goals of the partnership can be agreed upon.

- Identify existing mechanisms to reach goals. Be aware of currently available means of implementing a partnership. These may be easier to implement than ones that have not been tried.

- Identify new and potential mechanisms to reach goals. These new mechanisms may be just what a program needs for success.

- Identify barriers. Recognize the potential problems that might be encountered. These barriers may be regulatory, diversity of interests, or even personality conflicts.

- Develop a formal plan. A formal plan of the partnership needs to be documented.

- Identify special responsibilities. The formal plan should include a description of the individual responsibilities of each partner. These responsibilities may include who does what, who pays for what, and a schedule of events. 
- Create an organizational structure. Internal and external organizational charts will better outline the relationships and responsibilities of all players.

- Written agreement/commitment. A signed agreement that spells out the commitment of each partner will help ensure their support, even if the agreement is not binding.

- Implement. Go ahead with your plans!

The above steps provide a useful guideline for states to follow when developing a partnership. Some of the qualities or needs that should be inherent in a partnership include creativity/spontaneity, mutual benefits for all players, quality and equality, clarified roles/responsibilities, and flexibility in partnership evolution that comes from patience and stamina. 
MARKETING AND PROMOTION OF LOW-INCOME RESIDENTIAL RETROFITTING

Most of the programs chosen for PILIRR grants propose to develop sustainable sources of funds to be used directly for weatherization or to be leveraged through the use of such mechanisms as interest rate buy-downs. In many of the proposed programs, the necessary resources are expected to primarily come from nonpublic sources. Therefore, some thought has been given to providing information to grantees and their partners to help them generate adequate and sustainable resources.

In effect, grantees and their partners will need to "market" the notion of support for low-income residential retrofitting to individuals, groups, and businesses. Moreover, states may need to use marketing-like methods to identify appropriate partners and to secure their participation. The marketing information in this chapter has been organized in two parts. In the first part, general notions of marketing strategy and how they relate to concept marketing are discussed. This background material should be useful in helping PILIRR grantees and their partners identify and think through the particular marketing approach that will best suit their needs and targets.

Following this general information, more specific information on the promotion part of marketing is provided. Although support for low-income residential weatherizing is a concept, not a product for which demand must be encouraged, the "sales" strategy should be carefully tailored to the particular target that has been selected. The topic of promotion begins with a discussion of the primary potential targets for low-income residential retrofitting support. Following this, information has been provided on soliciting financial and material support from individuals, businesses and foundations. A second type of support, volunteer assistance, is also likely to be important to varying degrees in the PILIRR projects. The final segment of the second part of this chapter therefore takes a close look at the dynamics of creating and keeping an effective and motivated team of volunteers.

\section{GENERAL MARKETING STRATEGIES}

The term "marketing" is often thought to mean a set of business activities used to help a company identify and stimulate demand for the firm's products. While this is often the case, considering marketing from this one view is much too limiting. A more expanded view of marketing is "the set of activities by which the demand structure for goods, ideas, and services is managed in order to facilitate the exchange process satisfactorily" (Rom 1982). It consists of the organization analyzing the needs, perceptions and preferences of the target markets as the basis for program design, pricing, placement, promotion and service. This view of marketing encompasses such diverse subject areas as consumer behavior, pricing, purchasing, sales management, product management, marketing communications, packaging, channels of distribution, marketing research, social issues, wholesaling, retailing, and international marketing. 
Marketing Efforts by Nonprofit Organizations

More and more nonprofit organizations in the United States are actively marketing ideas and services to attract support for their causes and/or to see that their services are distributed to those who need them. For example, the American Cancer Society and the American Heart Association have had some impressive successes based upon their marketing strategies and promotional campaigns that try to persuade smokers to abandon the habit because it is unhealthy. There has been widespread support for this cause, but the groups' funds are limited, particularly when measured against the huge advertising resources of the cigarette industry. Nevertheless, scores of cities in the United States have passed laws that prohibit smoking in public places, and it has become very common to provide nonsmoking areas in other facilities used by the public, such as in restaurants.

\section{Marketing Plan Goals}

The purpose of a strategic marketing plan is to systematically organize and direct marketing activities to accomplish measurable, realistic, and desirable goals. To this end, the marketing plan consists of strategies (goals), tactics (methods of achieving the goals), and controls to ensure that the goals are met. The overall objective of this planning process is to produce an optimal marketing plan that will bring out the desired change or reaction from its target audience.

The fact that a plan is considered optimal does not, however, guarantee that the desired change will occur. Some types of changes are difficult to achieve and require a variety of marketing activities appropriate for the type of change (goal) desired. Four types of changes may be goals to marketing plans in a given situation: cognitive, action, behavioral and value. They are discussed below in order of their difficulty to achieve (i.e., from least to most difficult).

\section{Cognitive Change}

A marketing plan designed to create a cognitive change is seeking to change levels of awareness, education or knowledge. This type of change is relatively easy to achieve because it does not need any value, attitudinal or behavioral changes to be made. If action is required after the cognitive change has been accomplished, then value, attitudinal and behavioral alterations may become obstacles to achieving the desired action (goal). For example, a promotional campaign designed to create or increase the level of awareness concerning the problem of inefficient and poorly weatherized homes of low-income people would be attempting to provoke a cognitive change. This may be the first step in increasing the public's awareness of the need for support in residential retrofit.

\section{Action Change}

This is a second-level change and thus is harder to achieve than a cognitive change. Marketing plans with the goal of action change are attempting to induce persons to take specific actions within a specific period of time, 
such as donate funds or volunteer support or take advantage of low-interest loans for residential retrofit. The reason this type of change is more difficult to accomplish is because now, in addition to creating awareness and knowledge, it is desired that the person (target) take action based upon this new information, which involves costs (time, money, etc.) to the individual.

\section{Behavioral Changes}

While an action change induces a one-time response, a behavioral change calls for a permanent modification of one's behavior in particular circumstances. Behavioral changes involve learning new behaviors and habits that occur over time. Attempting to gain long-term volunteer support from individuals would require a behavioral change in these people since such a commitment would entail a change in the persons' everyday lifestyles. This type of change is thus much more difficult and takes longer to achieve than either of the two previous change types.

\section{Value Changes}

The last category of change, and the most difficult to accomplish, is a change in an individual's values. Because values are few in number, and at the root of our behavior, actions and awareness, they form the foundation of an individual's choice. The appearance of information, actions or behavior that is inconsistent with an individual's value set creates dissonance (strain or stress), and this intruding stimuli is then usually ignored, avoided or rationalized away. Marketing efforts that call for value change are not likely to succeed because their message becomes the intruding stimuli, and are hence avoided.

Residential retrofit marketing plans should concentrate their efforts on the first three goals: cognitive, action or behavioral changes. These goals are more likely to be achieved if they are induced properly and time expectations are realistic. These types of changes relate well to a hypothetical situation where a state and nonprofit community-based organizations are involved in a partnership to provide residential retrofit to low-income households. The state would be most equipped to market the idea and need for support of residential retrofit across the state (or in selected areas) to increase awareness. Here, the state's role might be that of an influencer to those people who may consider the decision to donate or volunteer. These state efforts would supplement the efforts of the nonprofit groups that are actually recruiting public support in terms of materials, money, or volunteer hours. These community-based groups would be trying to influence an action change (gain in-kind support), whereas the state would be trying to increase awareness (cognitive change) of a public problem or need.

Value changes should be avoided because they generally produce counterproductive results--generally resistance to any program or measure. With the proper or appropriate goal(s) selected, a marketing plan to achieve them can be developed. 
Features of a Marketing Plan

The following is a general marketing plan that has been adapted to a situation in which the firm or organization is attempting to influence the response of the target audience. This marketing plan is different from a situation in which a product or service is being sold directly to consumers.

Problem Statement - A clear understanding of the root problem to be solved and a clearly defined target audience are essential to the program's success. A marketing plan cannot be successful if it focuses on symptoms or addresses the wrong problem.

Goal Setting - Once the problem is properly defined, goals that will help solve the problem need to be established. As discussed above, the goals will be cognitive, action, behavioral or value changes on the part of the target audience. The appropriate goals must be selected in terms of effectively solving the problem as stated. The goals must be stated in realistic and measurable terms if they are to be achieved and used for control purposes.

Target Market Segmentation - Because the target audience may not be customers (or constituents) of the organization initiating the marketing plan, this step becomes especially important. Identifying the correct target markets allows the marketing effort to focus its attention upon the appropriate group(s), and because it narrows the focus, results in more cost-effective marketing efforts. Target audiences can be identified by a variety of segmentation variables such as demographics, geographics, psychographics (1ifestyle, attitudes, etc.), price sensitivity or role in the consumer decision. The variables used to segment the market must result in meaningful groupings of more homogeneous consumers or influences in order for marketing efforts to be effective.

An example of a state program that might use segmentation to define its target audience could be a program that offers low/no interest loans to landlords of low-income housing units. The state would best use its resources by identifying, for example, a subgroup of these landlords who pay the utility bills of their tenants to target those who are most likely to take advantage of the loan program. Landlords who pay their tenants' utility bills would have an extra incentive to increase the energy efficiency of the residence.

Consumer Analysis - Once segments have been identified, the consumers contained within each segment must be analyzed in terms of their characteristics, behavior and attitudes. In this way, proper communication and incentive structures can be developed to induce the change(s) desired.

Influence Channel Analysis - This step requires the marketer to determine which players in the consumer decision process (influence channels) are most important to the consumer's decision. Examples may be financial institutions, charitable organizations, advertisements, friends, etc. Marketing efforts and incentives can be focused correctly on the players with the highest impact only after they are identified. 
Marketing Strategy Development - At this point, alternative marketing approaches can be evaluated in terms of their ability to produce the desired results. Through this process, an overall marketing strategy can be developed to reach the desired goals. The marketing mix, which is a particular blend of controllable marketing variables the state can use to achieve their objective in the target market, can be classified into the following:

- Product or merchandise planning - The product(s) that a firm or organization is marketing can be physical, such as a boat or toothpaste. Often, the product is a service such as insurance, tours, or banking. The "product" may also be a person such as a performer or political candidate. Sometimes it is an organization that is being marketed, like the National Football League or the American Red Cross. Finally, the product can be an idea. For example, Mothers Against Drunk Driving is spreading the idea of not drinking alcohol while driving. The previous examples relating to residential retrofit would also be marketing an idea.

- Price - For consumer goods, the optimal price of the product is set at the level which optimizes some objective that has been set by the company - usually profit. Price is less relevant in the types of marketing programs that have been discussed; however, in this case it might be the interest level of the loan to landlords that maximizes the number of landlords that take advantage of the program, while keeping the interest rate at a level that will allow for growth in the loan pool.

- Place - The place or distribution network should make it convenient for the target audience to obtain the product or information. For the loan pool for landlords, this might be where the loan is available.

- Promotion - Promotion is an extremely important ingredient to the overall marketing plan, especially when the goal of the marketing plan is to create public awareness and support for an idea or issue, such as the need for residential retrofit. Promotional strategy deals with the blend of advertising, personal selling, sales promotion, and public relations that the company or organization uses to communicate with its market. For the loan program for landlords, promotion should communicate the comprehensive benefits of the retrofitting to the landlords in ways that are tailored to their primary interests (profit, improved tenant satisfaction, convenience, low up-front costs).

Implementation - Tactical planning puts the strategy decided upon into action. Specific budgets, media mixes, distribution channels and incentive structures, for example, are designed and put into effect. These should also be stated in measurable, realistic terms.

Control - Lastly, monitoring results against desired goals will indicate the effectiveness of the strategy and/or tactics used to achieve the desired goal(s). At this point, the plan can be adjusted if results are less than satisfactory. 
Summary

Modern marketing pervades nearly all organizations. Not all organizations or firms use marketing techniques to make a profit, as is evident with the numerous nonprofit organizations that have developed marketing plans. A marketing plan that defines a specific problem and strategically incorporates the variables in the marketing mix will help an organization or firm reach its goals. The next section on promoting residential retrofit will address promotion and fundraising issues that nonprofit organizations involved in PILIRR might use to recruit volunteers, materials or funding.

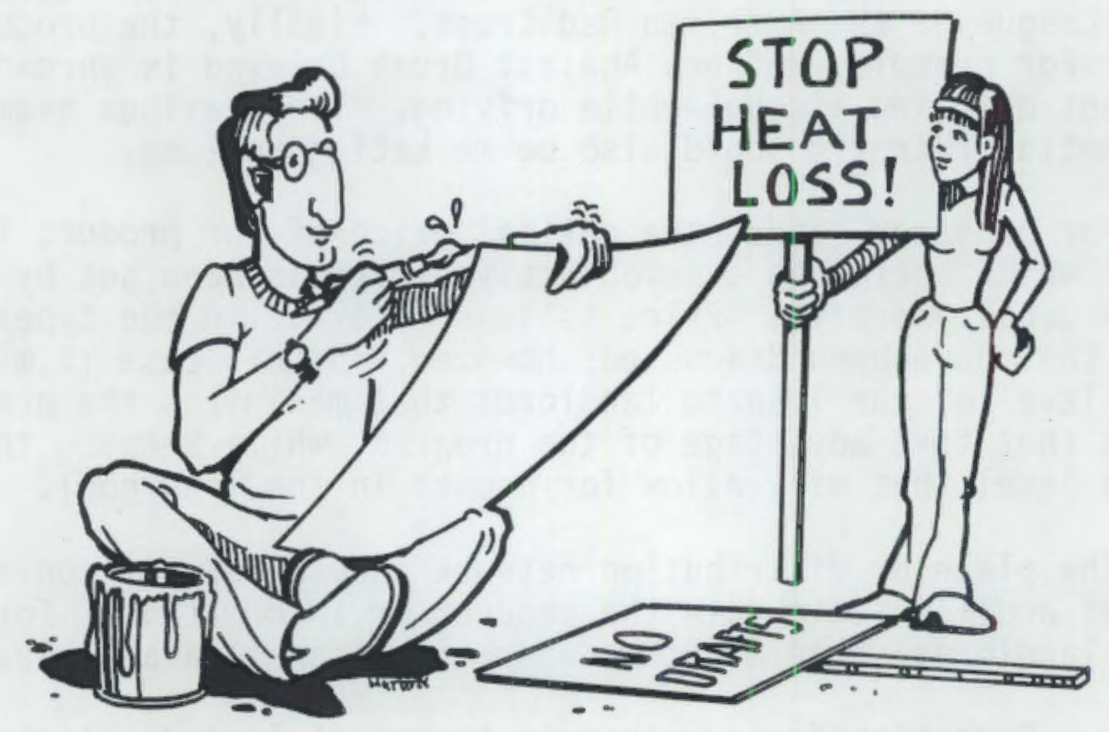

PROMOTING LOW-INCOME RESIDENTIAL RETROFITTING

A major objective of PILIRR is to help the states to develop effective ways to market support for low-income residential improvements from private and nonprofit sources. This section discusses promotional strategies for obtaining support for low-income improvements. Those strategies include determining the targets for marketing efforts, soliciting funds and materials, and planning and implementing a program to obtain volunteer support.

\section{Targeting Low-Income Weatherization Marketing Efforts}

As mentioned earlier, promotion is one element of the marketing mix and an integral part of the overall marketing plan. Before strategies can be developed to promote funding, material or volunteer support, specific target groups must be identified. Communications to the different target groups need to be tailored individually to each group so the message will be most. effective. For example, if funds are being solicited from a foundation, a brochure describing the current weatherization efforts of the group may not be acceptable. Rather, a proposal detailing the group's specific needs would be more appropriate for most foundations. 
Potential supporters for low-income weatherization can be divided into three categories:

- Nonprofit organizations - Nonprofit organizations can be an excellent source for recruiting individual volunteers or the entire organization to become a member of a partnership designed to better provide low-income weatherization to citizens in the local community.

- Private organizations/foundations - Private organizations, particularly local ones, can be very helpful in providing materials either free or at cost. Businesses that are involved in manufacturing or retailing weatherization-related materials or services are very valuable supporters. Businesses can also be a good source for displaying posters or distributing brochures or pamphlets for advertising a particular organization's lowincome weatherization efforts. Private organizations may also be good targets for soliciting funds. Foundations, particularly those in the same region as the group soliciting funds, can be an excellent source for funding.

- Utilities - In many states, utilities are mandated by their public utility commissions to provide a certain level of funding for low-income weatherization to their customers. In many cases this involves conducting energy audits, installing energy conservation measures and making necessary repairs. A collaborative effort among utilities and community action agencies or other nomprofit organizations can provide for a more efficient way to support low-income energy-efficiency improvements.

Many of these organizations are currently involved in providing some type of support for low-income residential retrofitting. However, strategically developed promotion and marketing by the sponsor of a low-income housing retrofit program can be effective in broadening the extent and increasing the level of such support. Well-directed promotion also can be very helpful in getting low-income weatherization support from individuals and organizations who previously have not been involved. Therefore, several of the promotional approaches listed below may be helpful for soliciting funds and materials and recruiting volunteers. The approaches suggested here have been made general, so that they could be used by any organization that wants to start a residential retrofit program or that wants to improve its existing program. 


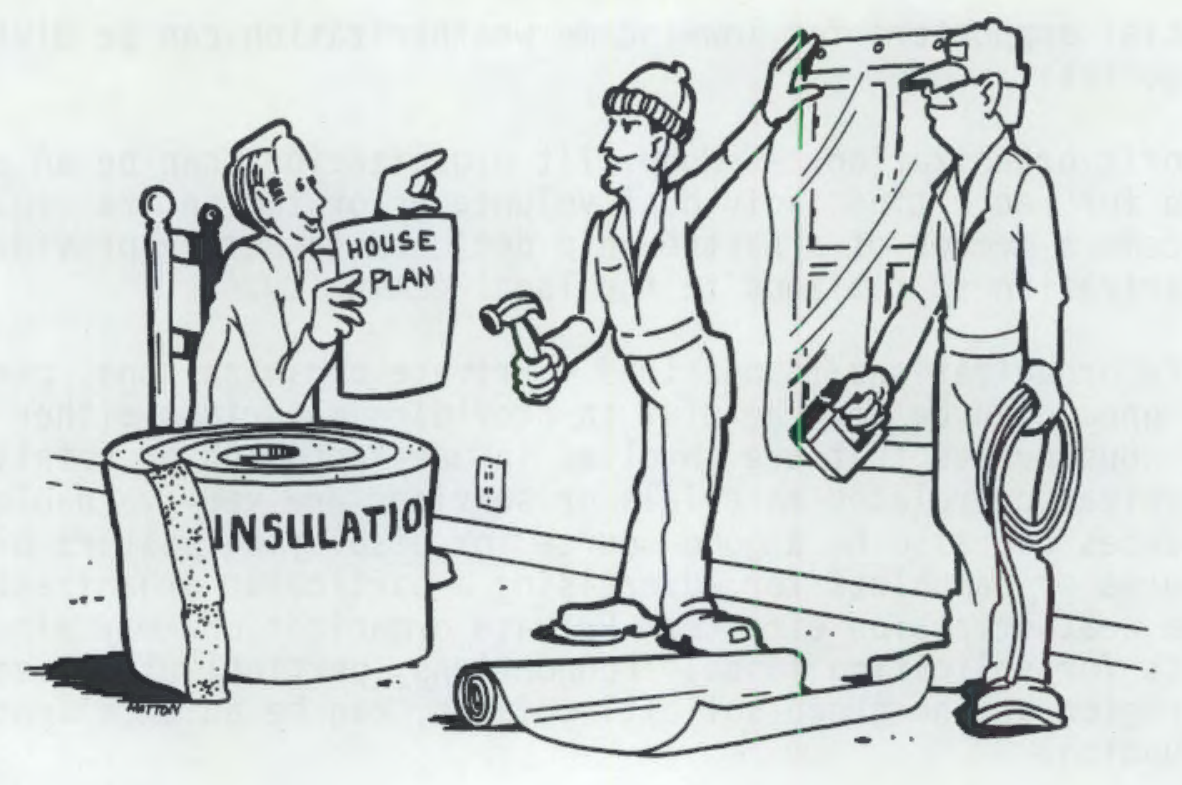

Soliciting Funds and Materials

Because of the uncertainty of federal funding for low-income residential retrofitting, several states have begun developing new sources for funding. One way in particular is by forming partnerships with utilities, nonprofit groups and other businesses or organizations in local communities that are also interested in supporting low-income residential retrofitting. Although the partners are often themselves a source of supplemental resources, it is also common for these entities to solicit support from other types of contributors. The purpose of this section is to briefly review some ideas and suggestions on how states and the states' partners in low-income residential retrofitting can solicit funds and materials successfully.

There are many ways to solicit funds and materials. However, most experts on fundraising suggest some basic rules:

1. Develop a plan - Ideally, a specific person in the organization will be responsible for fundraising activities. That person will want to develop an overall fundraising plan that includes specific details on all steps involved and the person responsible for each step. A fundraising project may include several subtasks, such as approaching local businesses for materials, writing for grants, or promoting a raffle. The coordinator or fundraising committee should carefully evaluate the different methods that can be used to solicit funds and/or materials and chose the methods appropriate to the organization. Plans should be developed for each subtask and for each person who will be responsible for carrying out the subtask. As the subtasks are carried out, the coordinator may want to request progress reports.

2. Set goals - An organization must be realistic in planning how much money will be raised in fundraising activities. Prior experience is most helpful in estimating fundraising profits. If an organization has not had any 
fundraising experience, other nonprofit organizations in the area may be able to help determine reasonable expectations. The announced goal or target should be low enough so that it can be achieved if no unexpected problems occur. Once an organization successfully reaches a fundraising goal, it will be easier to find people to help during the next fundraising activity and it will increase the public's confidence in the organization's judgment.

3. Keep spending to a minimum - When trying to solicit funds it is important to keep spending at a minimum. Members of an organization may have business or foundation relationships that can be used to solicit materials and funds. Also, a letter from someone of prominence from the organization or from the general public will help when approaching a business or foundation for assistance. A letter or personal contact should include the benefits of the donation not only to the organization but to the contributor. However, if possible, businesses or foundations should be approached in person or by telephone rather than through a letter. It is more difficult to turn down a person than it is to ignore a letter.

4. Evaluate the fundraising efforts - A fundraising effort should be evaluated during the campaign and at its conclusion. An accounting system should be set up to track all costs incurred. Also, the different fundraising activities should be itemized in order to evaluate the effectiveness of each. This will help in planning the next fundraiser, in deciding what to try again the next time, and in making improvements. Talk to everyone involved in the fundraising activities and get their opinions and suggestions on how to do it better the next time.

5. Acknowledge the workers - It is extremely important to thank everyone in the organization who contributed time and effort to the fundraising project. This can be done informally such as a simple thank you, or formally such as a banquet. (This will be discussed more in the next section of this chapter.) It is also extremely important to thank the businesses and foundations that contributed in some way. This can be done in a letter, phone call, or possibly in an article in the local newspaper. For example, Westside Energy Coop in Denver, Colorado, gives private companies and nonprofit organizations a certain amount of space on a promotional sign or billboard, depending on the amount of funds donated or the number of volunteers in attendance from the group. The space is intended to recognize their donations of money and/or manpower. Depending on the contribution, an organization can provide the contributor with detailed information about the gift for tax purposes. Progress letters can also be sent to the contributors to let them know how their contribution is being used. Developing an ongoing relationship will benefit the organization over the years to come.

\section{Fundraising Targets}

An organization can direct its fundraising activities at various markets. The rest of this section will focus on three major target markets: individuals, foundations and corporations. 
Individuais. Individuals are by far the largest source of charitable donations, accounting for over $80 \%$ of donations made each year (Kotler 1982). Almost everyone makes a contribution to one or more organizations each year. The amount donated will vary by an individual's age, education level, income, sex and other characteristics. According to Kotler (1982), relatively more money is donated by "high-income people, people in their middle years, and people of high education." Therefore, an organization should consider these characteristics when segmenting individuals according to their "giving potential." Fundraising activities can be developed to solicit different levels of funding from different segments of the population. For example, an auction is an excellent way to receive large donations from individual givers. Frequently, organizations segment their target markets into three groups: small, medium and large donors.

An organization should consider several factors when selecting the types of fundraisers most appropriate for the organization:

1. Size of the project - The larger the organization, the bigger the fundraiser can be. For example, a small group might be wise to consider small fundraisers such as bake sales, book fairs, or car washes. However, a relatively large, established group might want to consider an auction, golf tournament or a talent show. If this is the group's first fundraiser, it may be best to start small and gain some experience before "tackling" a large project.

2. Number of promotional projects - This will also depend on the size of the organization. Large organizations may only want to undertake one large annual project that is targeted to wealthy individuals in the community. A formal dinner and dance in combination with an auction might be one example of a large project that would involve a lot of planning and people in order to be done successfully. On the other hand, a small group may want to plan several small projects during the year that would not require much financial investment yet still have a good chance for financial success. This would also be good advice for a group that has never been involved in fundraising activities.

3. Interests of the group - Before one or more fundraising projects are selected, the members of an organization should confer to determine their interests. An ideal situation would be to link fundraising activities with the activities of the organization's programs. An excellent example would be the "Caulk-a-thon" conducted by Westside Energy Coop in Denver, Colorado. Volunteers promote the event using several methods, such as asking people to put bumper stickers on their cars. While doing this, the volunteers are also soliciting for contributions of funds or volunteer hours. Volunteers are also trained to do caulking in the low-income households. Businesses in the community are solicited for donations of materials and funds.

There are many types of fundraising projects an organization may choose to undertake. The projects can be relatively small and involve little initial investment, such as selling a service like washing cars at a gas station or selling tickets for a food bazaar. Or, a fundraising project can be quite 
large and require a substantial prior investment by the organizations. This might involve holding an auction or sponsoring a show with big name entertainment.

Many other types of fundraising activities are possible. It is more a matter of how creative an organization can be. Whatever the activity, effective marketing is a very important factor in the activity's success. Marketing activities can be useful for recruiting volunteers, soliciting materials and money, bringing people to the event, and promoting good public relations. Some of the promotional materials that are available include posters, flyers, bumper stickers, exhibits, billboards, balloons, and envelope stuffers. Free publicity from local newspapers, radio stations, service clubs, churches and businesses may also be available. Word of mouth should be the number one marketing method. Most fundraising experts will claim that this can be one of an organization's most valuable marketing techniques. Several books about fundraising are listed below; these and other similar materials may be good resources for fundraising at the community level:

Fund Raising for the Small Organization by P. Sheridan (1968)

The Grass Roots Fundraising Book: How to Rajse Money in Your Community by J. Flanagan (1977)

Handbook of Special Events for Non-Profit Organizations by E. Liebert and B. Sheldon (1972)

Fund Raising: A Guide for the Non-Profit Organizations by N. Pendleton (1981)

Dollars and Sense: A Community Fund Raising Manual for Women's Shelters and other Non-Profits by Western States Shelter Network (1982)

Foundations. Foundations are nonprofit organizations that have been set up to give money to worthwhile causes. They can be classified into the following categories:

1. Family foundations - set up by wealthy individuals to support a limited number of activities of interest to the founders. Typically, family foundations do not have permanent offices or full-time staff members and therefore usually are not included in foundation directories. Generally, decisions are made by family members and/or counsel.

2. General foundations - set up to support a wide range of activities and usually run by a professional staff. They can include the extremely large, well-known organizations such as the Ford and Rockefeller Foundations, which support a wide range of causes and give most of their money to large well-established organizations. Or, they can include more specialized general foundations that give money to a particular cause, such as health (Johnson Foundation) or education (Carnegie Foundation).

3. Corporate foundations - set up by corporations and allowed to give away up to $10 \%$ of the corporation's adjusted gross income. 
4. Community foundations - set up in cities or regions and typically centralized under community management. The grants are usually restricted to the local area.

Currently, there are over 26,000 active grant-making foundations in the United States. However, most of these have rather small assets. Approximately $15 \%$ of the foundations account for over $90 \%$ of all grants. Some sources state that the acceptance ratio among larger foundations is about one in ten, whereas some small foundations accept most of the applications they receive. With the proper planning, an organization can select the few foundations that would be the most likely to support its given project or cause.

Fortunately, many good resources are available to do research on foundations. The best single resource is known as the Foundation Center, a nonprofit organization with research centers in New York, Washington, and Chicago, which collects and distributes information on foundations. The primary publication of the Foundation Center is the Foundation Directory (1981), which is revised every few years and can be found in most public libraries. The directory lists over 2500 foundations that either have assets of over $\$ 1$ million or award grants of more than $\$ 500,000$ annually. The directory describes the general characteristics of each foundation, such as type of foundation, types of grants, annual giving level, officers and directors, location, particular fields of interest, and contact person. The directory also contains an index of field of interest, listing the foundations that have a stated interest in each field and whether they gave money to that field last year.

Several other publications produced by the Foundation Center include:

1. National Data Book - Brief descriptions of over 26,000 foundations.

2. Source Book Profiles (1981) - A loose-leaf subscription service with indepth analyses of 1,000 major foundations.

3. Foundation Grants Index Bimonthly - An annual index that lists by foundations, subject, state and other groupings, and the grants that have been given in the past year.

As previously mentioned, many requests for foundation grants are declined. Requests may be denied for a number of reasons, such as there are not enough funds to go around, the application falls outside the foundation's field of interest, or the application was poorly prepared. Because of the competition for foundation money, an organization requesting a grant should do all of the necessary homework before submitting a proposal.

Nonprofit organizations will have the most success in getting a grant if they try to find foundations that have interests similar to their own. It is also important to look for foundations that regularly award grants approximately the same size as what the organization is requesting. Too often a small nonprofit organization will send a proposal to the Ford Foundation because it would like the support of a well-known foundation. However, the Ford 
Foundation only accepts about 1 out of every 100 proposals and may be less inclined to help a small nonprofit organization than would a more regional or specialized foundation.

After an organization gathers information about several foundations' programs that might have high interest in its project, the organization should try to qualify its level of interest before investing a lot of time in preparing a grant. Foundations should be willing to respond to a letter of inquiry, phone call or possibly a personal visit to tell an organization how interested they are likely to be in a project. Based upon this information, the number of foundations on an organization's list can be further reduced to those most appropriate to the organization's goals and programs.

Each foundation should be contacted to see if they have a specific application and/or format that a proposal should follow. Most proposals will require the following information:

1. cover letter briefly describing the proposal

2. the problem an organization is attempting to solve

3. background of the organization and previous accomplishments

4. amount requested

5. plan and schedule for raising other funds to supplement the grants and to accomplish the objectives of the organization

6. personnel working on the project and their resumes

7. budget for the project

8. method for evaluating the project

9. the financing that the organization will use after the grant ends.

When writing the proposal, an organization should be aware of the criteria that the foundations may use to evaluate it. Many foundations describe their criteria in their annual reports or they can be inferred by reviewing past proposals that they have supported. According to P. Kotler (1982) in Marketing For Non-Profit Organizations, the following are some of the most common criteria used by foundations to evaluate proposals:

1. the importance of the project

2. how worthwhile or needy an organization is

3. the ability of the organization to use the funds effectively and efficiently 
4. how much the foundation will benefit from supporting the proposal

5. how important it is to satisfy the person(s) who submitted the proposal.

If an organization can find out which criteria are most important to the foundation, the organization can emphasize those features in the proposal. For example, if the foundation places greatest emphasis on how much they will benefit from supporting the proposal, the organization should thoroughly describe the various benefits of that grant to the foundation.

Corporations. Business organizations are another source of funds for nonprofit organizations. By law, business organizations are allowed to give up to $10 \%$ of their pre-tax income as charitable contributions. However, in the past, yearly contributions have been only approximately $1 \%$ of their pre-tax earnings (Dermer and Wertheimer 1982). There are some important differences between foundation and corporate giving that should be kept in mind when deciding how to target fundraising. Making charitable contributions is a major activity for foundations as opposed to corporations, where it is a minor activ$i$ ty. The amount given by corporations will vary with the level of their current and expected income. Corporations will also be more concerned with the personal benefit they can expect from their grants. Corporations are also in a position to offer gifts other than money. For example, a business can be approached for goods (materials for weatherstripping), services (asking a utility to evaluate a percentage of the audits done by subcontractors) or space (use of a conference room for monthly meetings involving several nonprofit organizations).

There are numerous reasons why corporations make donations of money or materials to nonprofit organizations. Those reasons should be considered when an organization is setting up a fundraising campatgn. Generally, a corporation will only support an organization if it is in their own best selfinterest. Some businesses may make donations to gain acceptance by the public for their products or services or to better their image in the local community.

Most recently, the federal government has been encouraging private businesses to help support public programs. This has been particularly true as a result of the federal budget cuts in social services during the late 1970s. The Reagan administration has strongly advocated businesses to help fill the gap where public programs are no longer funded through government grants and programs.

To increase the chances of receiving a corporate donation, an organization must do the same kind of research as required for a foundation grant. Some of the information that should be collected on potential businesses includes:

1. corporate name, address, zip code, telephone number, major products produced or services provided, office locations, and earnings record

2. names of key individuals, such as the chairman, president, senior officers, public affairs officer and others involved in the actual selection of gift recipients 
3. the type of grants or materials they have donated in the past, recipients of grants or materials, and amounts given to similar organizations.

Like foundations, many sources of data are available on corporations. Some of the sources recommended by the Public Service Materials Center include:

1. Standard \& Poor's Register of Corporations, Directors and Executives contains data on some 37,000 U.S. and Canadian corporations and 75,000 executives.

2. Dun \& Bradstreet Million Dollar Directory - lists over 75,000 firms with a worth of at least one million doliars.

3. Dun \& Bradstreet Reference Book - lists over 100,000 companies.

4. Director of Corporate Advertisers - Tists 17,000 advertiser companies, arranged by industry categories.

5. Thomas Register of American Manufacturers - a directory of manufacturing firms by products.

Several other sources for information can be obtained from industry associations, business groups such as Chambers of Commerce, National Association of Independent Business, business journals, daily newspapers and newsletters.

The importance of segmenting a market and identifying the appropriate target market was covered earlier in this handbook. By identifying its target market, an organization or state office can concentrate its efforts on corporations that offer the greatest chance for success in terms of recruiting funds or materials. Some of the factors to consider when identifying the target market of corporations include:

1. Local business - Businesses located in the same geographic location as the organization would be an excellent prospect. The business may already be somewhat familiar with the organization, and any contributions given could be advertised locally.

2. Related activities - Businesses that are involved in activities that are related to the organization will be good targets. A business that manufacturers storm windows may be much more inclined to make a donation or provide materials than a business that manufactures computers.

3. Prior donations - Businesses that regularly make donations to nomprofit organizations will be much easier to reach than businesses without a history of making donations. This does not mean that an organization should not approach businesses that have not donated in the past, only that the success rate may not be as high.

4. Personal relationships - An organization should check with its members to find any possible relationships with local businesses. An established relationship can help in deciding how to approach a business. 
Once an organization has decided on the businesses it wants to recruit for funds or materials, an appropriate approach must be chosen. Larger corporations may require a specific proposal similar to those required by foundations. Smaller business may only require a letter or phone call. In either case, researching the business will help to decide this.

\section{Developing a Volunteer Program}

Some important differences between paid employees and volunteers need to be considered. One difference is that a volunteer is donating his/her time and effort and therefore can also choose the amount of time that will be devoted to the organization. Also, the volunteer normally will not have the training and experience that a paid employee will have. Volunteers are usually motivated by the cause itself, the purposes, and goals of the organization rather than the specific tasks he/she may be asked to do. Therefore, a volunteer may do a task not because he/she necessarily enjoys doing it, rather because he/she believes in the goals of the organization.

Volunteers have certain needs and expectations that should be recognized by an organization. These needs and expectations can best be explained by looking at some of the reasons given by people for doing volunteer work:

1. gratification from helping others, which in turn can enhance their own self-worth

2. a source for stimulation and socializing

3. training and work experience, especially for students and women who have been homemakers but intend to re-enter the work force.

These reasons or "benefits" can be emphasized and used in a promotional campaign to recruit volunteers. It should be remembered that these volunteers are the target market of the organization's promotional efforts (to recruit volunteers). As mentioned earlier in this handbook, the needs or benefits of the target market which, in this case, are those listed above, are the backbone of any marketing effort. Recruiting volunteers is the first step. It is important to have a carefully planned volunteer program in order to help maintain their support.

Organizations that are going to use volunteers should develop a program specifically geared to volunteers just as a company would develop a program for its employees. A successful plan might consist of the following parts:

- planning

- recruitment

- training

- management

- recognition.

Each of these parts is discussed in the following subsections. 


\section{Planning}

Good planning can help develop a good volunteer program and avoid many unpleasant problems. Ideally, the organization would want to have a coordinator or manager for the volunteer program. This person would be responsible for the actual program and serve as a liaison between the volunteers and the rest of the organization. The coordinator or those involved in developing the volunteer program should consider several of the following factors when developing the overall plan:

- How many volunteers are needed?

- What skills are needed?

- When are the volunteers needed?

- How much money is necessary to recruit and support the volunteers?

- What type of an attrition rate can be expected?

\section{Recruitment}

When recruiting volunteers, it would be helpful to develop one or more job descriptions for the tasks that volunteers will work on. The job description will help the volunteers know what roles they will be expected to fulfill and will help them decide if their skills, interests, and time limitations will match with what is needed by the organization.

Several methods of recruiting volunteers have been used successfully by many organizations. Some of the more effective methods include:

1. Word of mouth - This method has probably been more effective than any other method, especially with an established volunteer program. Volunteers who are happy with their work will want to tell their friends and acquaintances about their efforts.

2. Presentations at service groups and associations - The volunteer coordinator or volunteers who have been with the organization for a while are good candidates to talk about volunteering to organizations such as the Chamber of Commerce, Elks, Rotary, Kiwanis, business associations and other neighborhood groups. Many of these groups are willing to become involved in such a project but are unaware of the kinds of low-income assistance programs that are operating. Letters explaining a program's operation can be sent to these local groups to get volunteer support.

3. Churches - Church leaders can be recruited to approach their members about an organization's need for volunteers. Many church groups are involved in low-income residential retrofitting efforts, particularly as a source for volunteers.

4. Senior citizens programs - Senior citizens can make excellent volunteers because many have a lot of time and a desire to still be productive and made to feel needed. Senior citizens work especially well in the many programs that target elderly residents, because they make the recipients feel more comfortable interacting with others in their own age group. 
One example of seniors working well with their peers is the Hand in Hand program, established by the Oklahoma Gas and Electric Company.

5. Volunteer centers - The United States has approximately 380 volunteer centers that serve almost 100,000 private organizations and public agencies. Volunteer centers refer or place an estimated half a million volunteers each year. Volunteer centers are usually engaged in several of the following activities:

- volunteer recruitment/referral/placement

- consultation and training

- promotion of the meaning of volunteering and the benefits to community and volunteer

- recognition of volunteer efforts in the cominunity

- resource information on volunteering

- program development and community planning

- program administration and support.

Volunteers centers are listed in the phone book, or the National Volunteer Center in Arlington, Virginia, can be contacted for a listing of local volunteer centers.

6. Newspaper - Articles about a volunteer program or letters to the editor are an excellent way to market the need for volunteers. Newspapers also provide a way for thanking volunteers. Generally, newspapers like to cover special events in the community as special human interest stories.

7. Brochures/flyers - Brochures and flyers can be distributed door to door, sent to organizations that may have members interested in volunteer work, or left at businesses, libraries, grocery stores, or any other place where large numbers of people may visit. Utility programs rely extensively on flyers or "stuffers" that are sent along with utflity bills to potential weatherization recipients.

8. Television and radio - Public Service Announcements should be used whenever possible. Local stations, in particular, are often willing to make announcements about an organization's need for volunteers or special events. If an organization has a large budget for recruiting, paid advertisements could also be considered.

9. Open house - An open house will allow prospective volunteers to see and learn about an organization and the opportunities available to volunteers.

When recruiting volunteers, the benefits they will receive from their efforts should always be stressed. The benefits of weatherization training can also be stressed if such training will be given. 


\section{Training}

Training may or may not be required, depending on the volunteers' skills and the type of weatherization work to be done. However, the possibility should be evaluated because most volunteers will not have the specific skills required by an organization, particularly by organizations that perform the weatherization services. Some amount of training will invariably be required in such programs. A training schedule should be developed so the volunteer can decide if he/she has the time to participate. More than one schedule may be needed to include volunteers who have time restrictions. The Department of Commerce in Indianapolis, Indiana, organized a one-year program consisting of workshops that were conducted in 14 areas throughout the state. The workshops trained retired senior volunteers to teach and demonstrate several weatherization techniques to their peers.

\section{Management}

It has already been mentioned that a coordinator or manager would be beneficial to a volunteer program. For example, the Senior Energy Saver program, sponsored by the North Carolina Alternative Energy Corporation, stressed that it is worthwhile to pay a "key" motivated and enthusiastic person to oversee the recruitment and coordination of volunteers. The coordinator should be able to delegate specific tasks to each volunteer and then keep track of what work has been done. The volunteer should also feel comfortable about approaching the coordinator to discuss problems, ask questions or present ideas or suggestions.

The amount of management or supervision required in a program will vary depending on the tasks involved and the level of the volunteers' expertise with a given task. A coordinator can also help the volunteers feel important to the organization by keeping them informed about current activities, explaining why they are being asked to perform specific activities, and describing the results that can be expected on behalf of the volunteers' direct or indirect efforts.

The coordinator should also keep a file of the relevant information about the volunteer, such as name, address, phone number, the source of referral, task interests, an attendance record, the number of hours volunteered, and accomplishments. Some of this information will be helpful when recognizing the volunteers' efforts and when conducting future recruiting efforts.

\section{Recognition}

Even though recognition is mentioned last, it may be the most important aspect of a successful volunteer program. Everyone, whether salaried or volunteers, appreciates being recognized for their work. Recognition can help promote motivation in the volunteers and therefore can reduce the attrition rate and can help recruit new volunteers. 
Recognition can be given both formally and informally. Formal recognition might take place annually and involve a lunch or dinner banquet paid for by the organization. The volunteers could be recognized verbally at the banquet and/or be presented with a certificate or pin. Recognition could be based on number of hours volunteered, number of projects completed, number of years with the organization, or special efforts provided by the volunteer. Another type of formal recognition might be to have a "Volunteer of the Month" program that would be based on the volunteers' efforts.

Informal recognition should be ongoing. A stmple thank you or greeting a volunteer by name can have an important impact. Other examples of informa? recognition include sending a birthday card, writing letters to the editor of the local newspaper and other media thanking the volunteers for their assistance, taking time to talk with the volunteer, inviting the volunteer to staff meetings, and celebrating outstanding projects and achievements. 


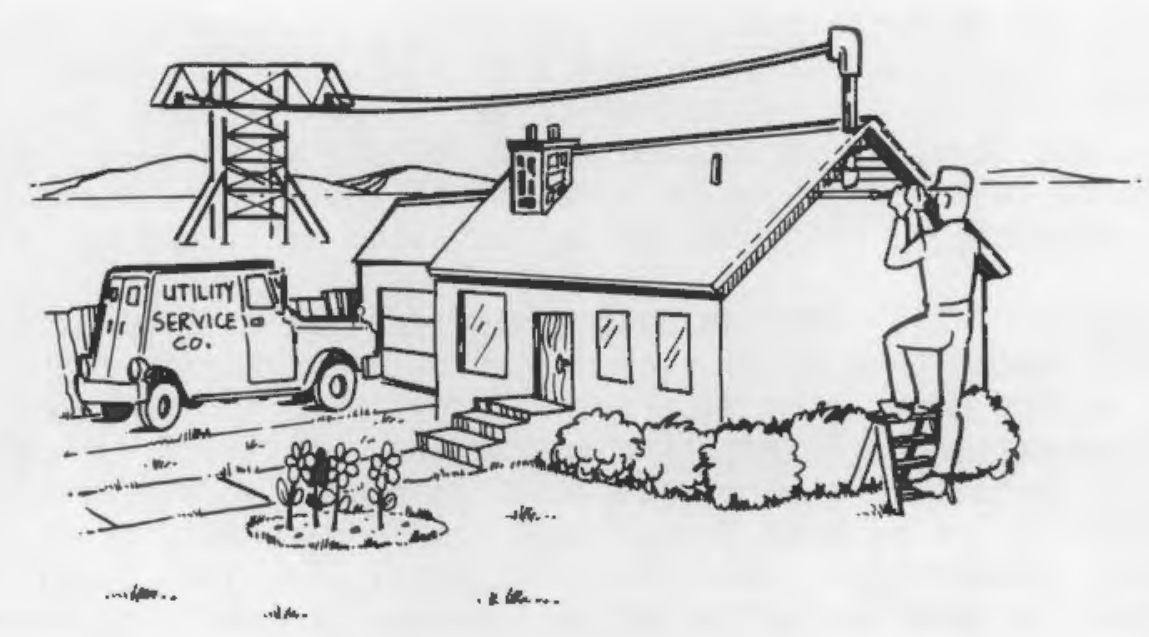

UTILITY ROLES IN CONSERVATION AND LOW-INCOME RESIOENTIAL RETROFITTING

All of the winning proposals for PILIRR grants identify utilities as a planned or potential source of support for low-income residential conservation improvements. The role of the utility in each demonstration program, and the type and expected magnitude of the support vary considerably from state to state, but the reliance on utility participation is universal. The purpose of this chapter is to present a concise but realistic view of utility involvement in conservation programs such as those to be undertaken in the PILIRR project. Specifically, the importance of understanding a given utility's operating environment will be discussed, followed by a review of incentives and disincentives to utility participation in low-income residential weatherization efforts that have been identified. It is hoped that this information will be useful to states as they plan and conduct their campaigns to secure the needed support from utilities.

\section{THE UTILITY OPERATING ENVIRONMENT}

Several factors help to shape a utflity's past and future activity in energy conservation. These influences make up a utility's "operating environment" and are critical to understanding and developing the best ways to approach utilities as potential partners in low-income residential retrofitting. States and local organizations that seek partnerships with utilities should take note of the following list and comments. This is not an exhaustive list. Other factors may well be equally important, but the general notion of the value of identifying important factors will not change.

The type of utility: The ownership of a utility (public or private) shapes the economic and regulatory climate in which it must operate. Investor-owned utilities, in general, face greater constraints (legal, institutional and economic) on their ability to participate in innovative conservation activities than do publicly owned utilities. 
The size and characteristics of a utility's residential load: The number and economic/demographic characteristics of a utility's residential customers can influence the type of residential conservation programs that utilities tend to support. The level of importance a utility places on conservation as an energy resource (which may also be a result of a utility's views toward demand-side management, discussed below) can also be shaped by this feature.

The climate: Utilities, as businesses, are generally more interested in reducing peak demand than total consumption, since capacity requirements (and the need to expand generating facilities) are linked to the former. When they use conservation to forestall construction, utilities with summer peaks (Southern and Sunbelt) are more interested in promoting measures that reduce cooling loads; utilities with winter peak demand generally prefer to support space heating conservation. Therefore, seasonal peak load requirements are very important in determining the attractiveness of specific conservation programs.

The size and expected duration of a utility's current energy supply: A utility awash in surplus energy may be hesitant to make heavy commitments to additional conservation activities, unless there are overriding regulatory, long-term planning or public pressure reasons to do so.

The utility's commitment to demand-side management: Utilities with a strong and active demand-side management policy may be more supportive of new conservation concepts to aid low-income households than utilities that use more traditional planning approaches. Utilities have found from experience that traditional programs are able to attract very little participation from their low-income customers for various reasons. If the low-income sector is a significant portion of a utility's residential load, reductions in energy consumption within that group can be viewed as an important supply resource in the utility's long-term plans. Accordingly, such a utility may be eager to participate in innovative programs that can be sold to management and regulatory bodies as demand control strategies.

Many, if not most, of these factors operate in concert when a utility is making decisions about its role in conservation and low-income residential retrofitting. Little can be predicted here about how these factors enter into the equation. What is important, however, is that states and local organizations carefully assess each utility's situation before making assumptions about its likely support for innovative low-income residential retrofit programs.

\section{REASONS WHY UTILITIES PARTICIPATE IN CONSERVATION}

Whether they are publicly or privately owned, utilities have a need and responsibility to operate efficiently--that is, not to operate at a loss over the long term. The profit motive is, of course, stronger for investor-owned utilities, but the controls on such utilities, as a form of monopoly, are correspondingly strong. Most conservation actions that are undertaken by both publicly and privately owned utilities are based on sound business 
decisions. Even conservation programs mandated by regulatory bodies are usually structured so as to promote, or at least to not impair, a utility's economic position.

Economists have argued that the primary economic incentive for regulated utilities to promote conservation is a tight regulatory climate. That is, when the state and federal regulatory controls prevent a utility from either charging a price that is high enough to make competitive rates of return or from realizing such rates of return because of a regulatory lag, the utility has a strong economic incentive to promote customer conservation of electricity (Synergic Resources Corporation 1984; Schroeder and Miller 1982).

A second economic rationale has become more important in recent years. Before the late 1970 s and early 1980s, little restriction was set on the utilities' practice of including facility construction costs in their rate base. However, when abandonment of partially built power plants became increasingly common, public utility commissions (PUCS) and courts began to interpret the costs of aborted construction somewhat differently. It has become very difficult for utilities to recover such investments as a result of court findings on the "prudency" of utility decisions to make immense capital investments in the face of uncertain demand. Therefore, even without regulatory mandates, utilities increasingly choose conservation over construction.

Demand-side management and planning, mentioned above, is a third and related reason why many utilities are choosing to participate in conservation. Strategic conservation--that is, conservation programs that are expressly designed to achieve some desired load-shaping goal--is one way that utilities have to control the need for new generating capacity and to deal with uncertain load growth. Although many utilities use load-management mechanisms that afford them direct control (e.g., air conditioner shut-off devices), strategic conservation programs are a far more common method used by demand-side management utilities to cut peak demand or reshape loads. (However, as discussed below, utilities cannot always rely on a specific amount of conservation response from such programs, or know when it will occur.) A strong related reason is that many conservation activities (including residential retrofitting) have impressive cost-effectiveness characteristics. That is, on a per unit basis [generally expressed as cents per kilowatt hour (kWh) for a megawatt of power], conservation is a better investment than construction, often by a factor of two or three. For example, estimates for new construction of coal-fired plants are about 6 cents per kWh in the Pacific Northwest; residential retrofit programs saving an equivalent amount of electricity cost 2 to 3 cents per kWh (Northwest Power Planning Council 1986).

(a) Also, Fang, J. M. and B. J. Harrer. 1981 (Draft). Factors Influencing Electric Utility Energy Conservation Programs. Pacific Northwest Laboratory, Richland, Washington. 
As noted above, because the low-income conservation market has historically been very difficult to access through traditional programs, utilities are becoming more interested in supporting innovative ways to overcome the apparent barriers to proportional participation of this segment of the residential sector. Furthermore, if a utility program is close to achieving saturation levels of participation by higher income households, a demand-side management utility may be especially willing to contribute to efforts targeted toward low-income households.

The above are some of the main economic justifications for utility participation in PILIRR-type conservation programs for the poor. Utilities have other incentives as well. Although these additional reasons are not as directly tied to economics, they are nonetheless also based on businesslike decisions, rather than on altruism or on philanthropy.

\section{SOME ADDITIONAL INCENTIVES}

The environment in which utilities operate has become increasingly complex since the 1970s. Utilities have faced increased costs, increased numbers of bills that cannot be collected, challenges from citizen groups, and moratoriums on service disconnections imposed by PUCs in some states with cooler climates. In response to these pressures, a number of utilities have undertaken programs to help those who have the most problems paying their utility bills, especially when the rates increase rapidly.

Some of the utilities have been required by their state PUCs to develop a low-income weatherization program. However, most utilities, even those that have mandated weatherization services, have recognized a need to provide assistance to low-income customers. Six of the utility weatherization programs identified by PNL staff had been mandated to provide assistance to needy customers. Other utility motives for providing weatherization assistance to low-income customers include:

- Increasing their customers' ability to pay monthly bills: Utility companies and rate payers have a longstanding and regular financial relationship; therefore, it is in the utilities' best interest to improve the customers' ability to pay, especially for the low-income customers.

- Corporate responsibility: Most U.S. companies, including utilities, have recognized a corporate responsibility to become a worthwhile and concerned addition to the community in which they operate. Companies often satisfy these responsibilities by establishing charitable programs, usually ones related in some way to their business area, to help the community or country.

Smaller companies often donate funds or materials to charities or fundraisers in their communities. Larger corporations have established foundations to help the needy; for example, the McDonalds Corporation has established the Ronald McDonald House in several locations to provide parents of terminally $i l l$ children with a "home away from home" while their child is in treatment. In the case of 
utility companies, a large number of unpaid bills within a service area indicates that a poverty problem exists. One way for a utility to help the community address this problem is to undertake a low-income weatherization program of some sort. This is a logical means to satisfy their commitment to the community.

- Public image: Utilities, like other companies, are concerned with the public's perception of them. Low-income weatherization programs can promote a positive image for the utility in several ways. With such programs, the utility can reduce the number of needy customers because these customers are more able to pay. Thus, the utility avoids a negative public image created by shutting off service to less fortunate people. Also, these programs show that the utility recognizes its responsibility to the community as part of the solution versus part of the problem that poor people face. Ultimately, a feeling of goodwill is created between the utility and customers and may stimulate the customer to make more of an effort to pay utility bills.

An organization can point out these reasons as benefits to a utility when they are encouraging utilities to become involved in a low-income weatherization program.

\section{WHAT ARE SOME OF THE DISINCENTIVES TO UTILITY PARTICIPATION?}

Although most utilities now operate some type of conservation program, several disincentives may be limiting factors when a utility is asked to consider expansion of its conservation activities in low-income residential retrofitting:

- Reliability: Except in situations of very high and long-term energy surplus, utilities have traditionally viewed the risks of undersupply of energy as being greater than the risks of oversupply. From the utility's perspective, conservation programs do not provide a great degree of certainty as to how much conservation-generated energy will be available at any given time. Reliance on an uncertain supply source could increase the risk of future shortfalls, which is contrary to their mission of supplying reliable energy resources.

- Tax disadvantages of conservation investments: The tax treatment of conservation investments by utilities can create a barrier to the institution and expansion of such programs. Because a utility does not have definite ownership of the conservation measures it has helped to finance, it will not be able to declare, for tax purposes, the depreciation expense of the measure in the same manner as it would for a new generating plant. Thus, equal investments in conservation programs and new generating units will not yield the same tax advantages for depreciation.

- Potential liability problems: Although there are contractual mechanisms to safeguard utilities involved in conservation retrofitting, potential liability for damages due to ineffective or hazard-creating conservation measures can deter utilities from certain types of conservation programs. 
- Regulatory restrictions: The National Energy Conservation Policy Act of 1979 contained several restrictions on utility conservation activities. Among these was a provision that prohibited utilities from directly supplying and installing conservation measures. The Energy Security Act of 1980 amended some of the restrictions, but still allows utilities to supply and install energy conservation measures only through contractors or suppliers who are not subject to control by the utility (Section 546). These restrictions arise out of anti-trust concerns, i.e., that utilities, as monopolies, could adopt predatory pricing policies whereby they would use profits from their protected monopoly market to subsidize below-cost pricing in the competitive markets for conservation activities. As an example of the effect of this regulation, recent rulings in several states have, in fact, limited the ability of regulated utilities to promote the use of energy-efficient appliances.

- The difficulty of effectively reaching low-income populations with weatherizing programs: Utilities usually opt for programs that are not administratively complex. The difficulty of dealing with the barriers to rental and multifamily weatherizing can often discourage a utility from establishing active and effective low-income weatherization programs. However, this factor may also be viewed as an incentive to utilities to form partnerships with other organizations. This approach allows utilities to effectively avoid direct involvement in these more problematic activities, yet to meet regulatory requirements or demand-side management goals for reaching low-income populations.

- Negative public attitudes toward conservation for rental units: A final factor is public perceptions of programs designed to weatherize rental housing. Such an activity is often viewed in a hostile manner by ratepayers who consider low- or no-interest loans or other types of incentives payments to landlords unjustifiable. Although these incentives have been upheld in the courts, the legal uncertainty and controversy of programs that clearly benefit only specific ratepayers can serve to discourage utilities from participation (Schroeder and Miller 1982).

It can be seen that there are persuasive incentives and disincentives to utility participation in conservation and low-income residential weatherization. In reconciling the opposing considerations, utilities have often adopted the compromise approach of promoting customer conservation programs to the extent that they are cost effective and/or mandated by federal and state regulations. (a) This fact again reinforces the conclusion that utility participation in low-income residential retrofitting may rely primarily on business-related decisions. Therefore, to be successful, strategies to market support for PILIRR low-income programs to utilities should be carefully constructed and conducted so as to take these considerations into account.

(a) Also, Fang, J. M. and B. J. Harrer. 1981 (Draft). Factors Influencing Electric Utility Energy Conservation Programs. Pacific Northwest Laboratory, Richland, Washington. 


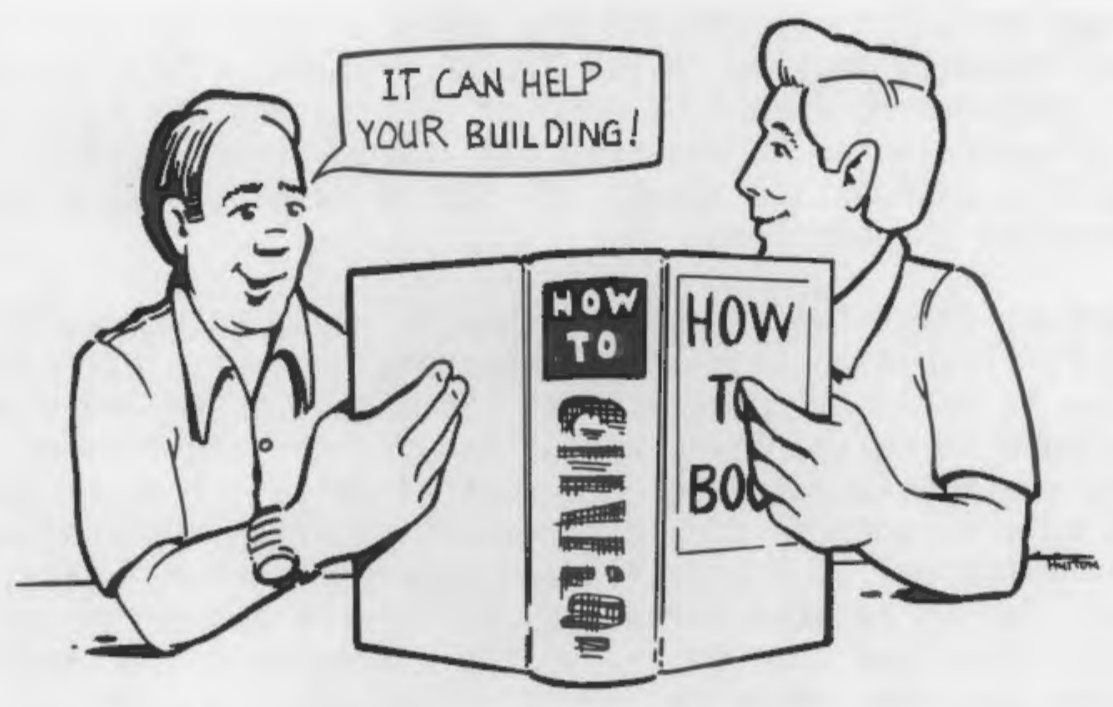

PROBLEMS AND OPPORTUNITIES IN RENTAL HOUSING RETROFITTING

Two PILIRR grantees (Washington and Iowa) chose to address the problems of weatherizing rental housing that is occupied by low-income households. In their proposals, both states justified their focus on rental housing by noting the following:

- A substantial proportion of low-income households (probably a majority) occupy rental housing.

- Rental and multifamily housing is seriously under-represented in most federal, state, utility and local weatherization programs.

- Traditional residential retrofit approaches do not seem to be able to penetrate the economic and institutional barriers that appear to be the primary cause of this under-representation.

- Energy-efficiency improvements of multifamily rental housing, when they can be accomplished, generally show better cost-effectivenes (a) ratios than similar single family home weatherization improvements.

(a) Support for this assumption can be seen in calculations by the Northwest Power Planning Council (1986) in its 1986 Conservation and Electric Power Plan for the Pacific Northwest region. The Council estimates that weatherization to the regionally cost-effective level of 5 cents per kWh results in average annual space heating energy consumption reductions of almost $300 \%$ for multifamily housing $(5,421 \mathrm{kWh} /$ year to $1,838 \mathrm{kWh})$. Weatherization of single family homes yields a reduction of about $180 \%$ $(11,047 \mathrm{kWh}$ to $6,077 \mathrm{kWh})$. 
These considerations underscore the importance and value of treating rental and multifamily housing in the PILIRR program. This chapter of the handbook was prepared to highlight some of the reasons why this housing sector has been under-represented in conservation and low-income residential retrofit programs, so that appropriate strategies can be developed by grantees and others to overcome the barriers.

There are at least two schools of thought about solutions to the problem of improving participation in retrofit programs by owners of rental housing. The first view is decidedly pessimistic. Some groups and individuals with direct experience in weatherizing rental housing contend that no incentive short of complete subsidization of the cost of retrofitting tenant-occupied housing is likely to achieve significant participation by landlords. These groups advocate the use of for-profit and nonprofit "energy service corporations" to provide the capital for energy efficiency improvements. The savings in energy bills are then used to recoup the investment. Strategies to enlist owners in these programs often recommend minimizing the potential for energyuse reductions, and emphasizing instead the value of property improvements.

A contradictory perspective is obtained from a study conducted by the DOE in 1982. In that study nine programs that have solicited participation by landlords in WAP-supported weatherization programs were evaluated (Funkhauser, Jensen and Reiff 1982). This study concluded that:

- landlords will participate in programs designed to require some kind of contribution (money, materials or labor)

- marketing the programs directly to landlords generates substantial program

- contribution programs are somewhat more time-consuming for the administering agency than the regular WAP program, but result in extending limited WAP funds.

The authors attribute the success of these programs to several factors. First, it is necessary for the state or local agency to make a strong commitment to working with landlords. The agency must establish credibility with important landlords in a community and must concentrate on actively selling weatherization directly to landlords, rather than attempting to appeal to them through tenants. Second, effective marketing programs stress the owner's potential benefits from the weatherization, while the more common approach (the report concluded) to weatherization highlights the tenants' benefits and minimizes the positive aspects of participation for property owners (Funkhauser, Jensen and Reiff 1982).

Finally, this report also concluded that screening and ranking applicants were effective ways to identify and recruit owners who were willing to contribute their share of the weatherization costs. Criteria such as the long-term viability of the building, the financial status of the owner, tenant eligibility, and sound building operation and management procedures were found to be useful. 
A more recent study conducted in Seattle by two large utilities is also useful in gaining an understanding of factors that improve the participation rate of landlords. The report for the study titled Background Information for Programs to Improve the Energy Efficiency of Northwest Residential Rental Property, P. L. Hendrickson (1986) evaluated several surveys of rental property owners and other research on rental housing retrofitting. The rest of this chapter has been excerpted from that report (pp. 5.1-5.6).

\section{OWNERS' DECISION PROCESS FOR CONSERVATION INVESTMENTS}

Survey information on decision criteria used by owners of residential rental property to make conservation improvements suggest that most owners do not use a rigorous quantitative approach in deciding to make conservation investments, are not inclined to borrow money to make improvements, and do not make improvements when funds are needed for other purposes. These facets of energy-efficiency improvement decisions are discussed below.

Reasons for Making and Not Making Conservation Improvements

Respondents were asked to give their two major reasons for action or inaction. The results of question are shown in the following table.

The principal reasons cited for making improvements were that "energy efficiency is important" and to "help the tenants." In one respect these apparently altruistic reasons are surprising. The literature on energyefficiency improvements usually assumes that improvements will only be made if they satisfy the owner's economic investment criteria. (a) This assumption is based on the reasonable notion that since the rental property itself is an investment, improvements to the property will be made only when the owner's investment criteria are met. Nevertheless, the responses are somewhat consistent with other parts of the surveys. First, the responses are consistent with the finding that most respondents used little economic analysis in reaching a decision. Second, the responses are consistent with the large percentage of individual owners among the survey respondents and the relatively long periods they plan to hold their properties. Finally, it should be noted only about one-half of the survey respondents made improvements. The remainder had apparently not been sufficiently motivated by altruistic feelings toward energy conservation to make improvements.

There was somewhat more of a tendency among owners of properties with five or more units to recognize and act on the economic aspects of improvements. These owners were more likely than small property owners to cite increased property value, increased rental marketability, and reduced energy costs as reasons for improvements.

(a) See for example, Southern California Association of Governments, Selling Energy Efficiency to Apartment Owners: An Investment Approach, (updated), available through the California Energy Extension Service, Sacramento, California. 
Reasons Seattle Rental Housing Owners

Made Energy-Efficiency Improvements(a)

Reason

Energy efficiency is important

Help tenants

Increase value of property

Increase marketability

of units

Tenant complaints

Energy costs got too high

Energy-efficiency improvements added in conjunction with

other planned improvements

Other

Number of respondents making improvements
Percent of Owners

$1-4$ Unit Properties (b) $>5$ Unit Properties (c)

$45 \%$

$33 \%$

$24 \%$

$20 \%$

$16 \%$

$20 \%$

$12 \%$

$16 \%$

$7 \%$

$8 \%$

$8 \%$

$24 \%$

$4 \%$

$2 \%$

$34 \%$

$37 \%$

$83 / 151$

$51 / 100$

(a) Respondents were asked to give their two major reasons for making the improvements.

(b) Survey Research Center (questions 20, 1984).

(c) Hall and Associates (question 26, 1984).

The Seattle City Light survey data on reasons for not making energy conservation improvements are shown in the next table.

The most popular reason for not making improvements was that the owners had other uses for available funds that were considered to be more important. A general reluctance to borrow money to make improvements was also evident, especially among owners of larger properties. Surprisingly, few owners cited a need for more information as a reason for not making improvements. 


\section{Reasons Seattle Rental Housing Owners Did Not Make Energy-Efficiency Improvements(a)}

\section{Reason}

Money needed for other things

Don't want to borrow

Interest rates too high

Don't believe I'll save money

Lack of time

Nothing needs to be done

Too much hassle

Tenant will benefit rather than owner

Need more information

Energy is insignificant part of operating budget

other

No answer

Number of respondents
Percent of Owners

1-4 Unit Properties(b) $>5$ Unit Properties(c)

$18 \%$ $36 \%$

$3 \%$

$14 \%$

$5 \%$

$3 \%$

$8 \%$

$4 \%$

$8 \%$

$10 \%$

$2 \%$

$7 \%$

$1 \%$

$8 \%$

$2 \%$

$5 \%$

$7 \%$

$15 \%$

$17 \%$

$68 \%$

$7 \%$

151

59
(a) Respondents were asked to indicate their two major reasons for not making any or more conservation improvements.
(b) Survey Research Center (question 30, 1984).
(c) Hall and Associates (question 32, 1984). 


\section{Decision Criteria Used for Conservation Improvements}

Data on the type of economic analysis used by residential rental property owners in the Seattle City Light surveys to make conservation improvements are shown below. Remarkably, the vast majority of owners said they used no economic analysis in making their investment decision. This result would not have been too surprising if the respondents were homeowners; it is surprising for investment property owners. Perhaps the owners made a mental calculation of the economic attractiveness of the improvement, but answered "none" to the question because the calculation was not committed to writing.

Type of Economic Analysis Used for Conservation Investment by Seattle Rental Housing Owners

\section{Type of Analysis}

None

Savings/investment ratio

Simple payback

Return on investment

Don't know

Other

Number of respondents
Percent of Owners

1-4 Unit Properties(a) $\quad>5$ Unit Properties(b)

$\begin{array}{rr}84 \% & 78 \% \\ 1 \% & 5 \% \\ 2 \% & 4 \% \\ 1 \% & 4 \% \\ 5 \% & 2 \% \\ 5 \% & 2 \% \\ 83 & 51\end{array}$

(a) Survey Research Center (question 21, 1984).

(b) Hall and Associates (question 27, 1984).

Other studies have found that return on investment, payback periods, and life-cycle cost are the most common decision tools for investment property owners. The Office of Technology Assessment (OTA) (1982) found that how fast a conservation improvement would pay back the investment in energy savings was the most common decision criterion. For most multifamily building owners, the minimum acceptable payback period ranged from 1 to 3 years (OTA 1982). A 1984 survey conducted for the Bonneville Power Administration found that commercial building developers were most likely to use return on investment and life cycle cost as investment criteria (Church/Davis Architects 1984). Developers using return on investment as a criterion looked for a return of $13 \%$ to 16\% in their projects (Church/Davis Architects 1984). This range is consistent with current return requirements. A recent survey of institutional real estate investors found that they were seeking a pre-tax yield, i.e., internal rate of return, of 12.75 to $15 \%$ in the third quarter of 1985 (Real Estate Research Corporation 1985).

The survey results shown in the above table suggest that, at least in Seattle, residential rental property owners do not evaluate energy conservation investments with the same criteria they (presumably) use for purchasing or developing a property. Many of the owners who make conservation improvements 
do so because they view energy efficiency as important and to help their tenants. They are apparently content to make improvements without making a formal economic evaluation.

Source of Funds for Conservation Improvements

Data on the sources of funds used by owners in the Seattle City Light surveys who had made conservation improvements are shown below. Owners of smaller properties were most likely to use funds generated from sources other than their property. Owners of larger properties used cash flow from their rental property as their principal source of funds.

Source of Funds Used for Conservation Improvements by Seattle Rental Housing Owners

\section{Percent of 0wners}

Funds Source

Capital reserve fund

Rental income

Loan

Seattle City Light zero interest financing

Combination of above

Other

Number of respondents

1-4 Unit Properties(a) $\quad 25$ Unit Properties (b)

$45 \%$

$16 \%$

$11 \%$

$31 \%$

$5 \%$

$4 \%$

$13 \%$

$20 \%$

$6 \%$

$16 \%$

$20 \%$

$16 \%$

83

(a) Survey Research Center (question 22, 1984).

(b) Hall and Associates (question 28, 1984).

None of the owners in the surveys for Seattle City Light were very inclined to borrow money from a conventional source to finance improvements, a) though there was a greater inclination to use zero interest financing available through Seattle city Light. Other studies have also shown that homeowners (Stern et al. 1985) and rental property owners (Levine et al. 1982) have little interest in borrowing or in loan subsidies to make conservation improvements, with the possible exception of zero interest loans. This attitude is especially prevalent for loans secured by a lien on the property. Apparently those homeowners and rental property owners who believe energy conservation is important and who have available funds proceed to make improvements. Owners without available funds do not generally think conservation improvements are sufficiently important to incur the risks and the out-of-pocket and administrative costs of obtaining a loan unless the loan carries no interest. 


\section{PREFERENCES OF OWNERS FOR ASSISTANCE}

The following material reviews the limited information found on the preferences of rental property owners for energy-efficiency improvement assistance. The three most preferred areas of assistance appear to be energy audit and analysis, financing, and information on the costs and merits of various energy conservation options.

Preference data from the two surveys conducted for Seattle City Light are shown below. The three types of assistance that the owners most preferred to obtain from Seattle City Light in decreasing order were energy analysis and audit, financing assistance, and inspection assistance after installation of conserva-tion improvements. Less interest was shown in obtaining assistance for getting bids, contractor selection, and supervising installation of improvements.

Approximately $50 \%$ of the owners in the Seattle City Light surveys expressed an interest in obtaining financial assistance from the utility to make conservation improvements. Owners of buildings with low-income tenants

Types of Conservation Improvement Assistance Desired by Seattle Rental Housing Owners

\begin{tabular}{|c|c|c|}
\hline Type of Assistance & $\begin{array}{c}\text { Owners of } \\
1-4 \text { Unit Properties (a) }\end{array}$ & $\begin{array}{c}\text { Owners of } \\
\lambda_{5} \text { Unit Properties (b) }\end{array}$ \\
\hline Energy analysis/audit & $52 \%$ & $65 \%$ \\
\hline Getting bids & $21 \%$ & $28 \%$ \\
\hline Selecting a contractor & $14 \%$ & $14 \%$ \\
\hline Supervising installation & $22 \%$ & $35 \%$ \\
\hline Inspection & $39 \%$ & $46 \%$ \\
\hline Financing & $42 \%$ & $52 \%$ \\
\hline Number of respondents & 151 & 100 \\
\hline
\end{tabular}

(a) Survey Research Center (question 35, 1984).

(b) Hall and Associates (question 39, 1984).

were most inclined to desire assistance. Those owners who did want assistance preferred a capital contribution from Seattle City Light to loans with an interest rate subsidy (Survey Research Center 1984; Hall and Associates 1984).

In 1981, 35 owners of residential rental property in Boston, Chicago, Denver, and San Francisco were interviewed as part of a study conducted by the Solar Energy Research Institute. The types of assistance most desired by the sample of owners were enhanced tax benefits, low-cost financing and better information (Levine et al. 1982). A consultant who has studied the problems of improving energy efficiency in rental housing also concludes that the 
greatest needs of landlords are better information and financing assistance (Friedman 1982). In contrast to these views of information needs, however, only a small percentage of Seattle owners who had not made energy-efficiency improvements cited lack of information as a reason.

\section{TECHNIQUES FOR CONVEYING INFORMATION TO OWNERS}

Those who are interested in improving the energy efficiency of rental housing are faced with the task of finding landlords and presenting a persuasive case to them. Many owners view their rental properties as investments only and try to minimize their involvement and time commitment to the investment. Attempts to persuade owners to invest in energy-efficiency improvements must overcome this underlying resistance. Owners of properties in low-vacancy markets where tenants pay for their own utilities are likely to be especially resistant.

Techniques for reaching owners include direct mailings; personal contact; advertising in various media such as radio, television, newspapers, and trade journals; and presentations at trade groups such as apartment owners association meetings. Each technique has particular merits and associated costs.

If direct mailings to or contact with owners is deemed desirable, an initial formidable hurdle is simply identifying and locating owners. Few owners of residential rental units live at the property site. Moreover, title to the property is often in the name of a partnership, proprietorship, or association that does not identify individual owners. In some cases, utilities will have the name of individual owners when the owner pays the utility bill for vacant units or common areas, or agrees to pay when the tenant defaults on payment. If the desired ownership data are not available from a utility, it may be necessary to use such things as business license records, tax assessor records, or privately compiled city directories to locate owners.

Direct mailings can be expensive and time-consuming, but one utility, Wisconsin Gas Co., found them to be effective in reaching owners (Fay 1984). Including information brochures on conservation programs in utility bill envelopes is also a potential way to reach landlords. If utility bills are paid by a third party such as the property manager or bookkeeper, though, a "bill stuffer" will not necessarily reach the owner. South California Gas Co., for example, found that many rental property owners in its service area do not actually see their natural gas bills because someone else pays it (Harbicht Research, Inc. 1984). Moreover, a property manager may have little incentive to pursue weatherization if he perceives that it will not affect his compensation.

Wisconsin Gas Co. found that radio and television advertising was their least effective technique for reaching landlords. This result is perhaps not surprising given the very select target market. The company did find, however, that radio and television advertising was reasonably effective in encouraging tenants to look for rental properties carrying the Wisconsin Gas energyefficiency certificate (Fay 1984). Pacific Gas and Electric Co. (PG\&E) has also found radio and television to be relatively ineffective for reaching rental 
property owners. The company has found face-to-face presentations to owners to be most effective. The Tennessee Valley Authority has also found that face-to-face meetings and discussions with rental property owners are the most effective approaches to convince them of the desirability of energy-efficiency improvements (Bleviss and Gravitz 1984).

PG\&E provides sales training to its auditors and installation contractors to help them convince rental property owners of the desirability of energy-efficiency improvements (Crowe and Callaway 1985). The themes that PG\&E has found useful in making presentations to owners include increased property value, better tenant relations, reduced tenant turnover, enhanced marketability of rental units, and state and federal tax benefits (Crowe and Callaway 1985).

Data from the surveys for Seattle City Light on where owners obtain their energy conservation information are shown in the following table; Seattle City Light and self-generated information were the most common information sources. Owners of larger rental complexes were more likely to obtain information through an apartment owners association than were owners of properties with 1 to 4 rental units.

Energy Conservation Information Sources for Seattle Rental Property Owners

Source

Seattle City Light written materials

Self

Newspaper

Apartment Owners Association

Television/radio

Trade journals

Friends/associates

Number of respondents
Percent of Owners

\begin{tabular}{|c|c|}
\hline $1-4$ Unit & $>5$ Unit \\
\hline Properties (a) & Properties (b) \\
\hline $45 \%$ & $43 \%$ \\
\hline $38 \%$ & $43 \%$ \\
\hline $26 \%$ & $16 \%$ \\
\hline $2 \%$ & $17 \%$ \\
\hline $7 \%$ & $6 \%$ \\
\hline $9 \%$ & $6 \%$ \\
\hline $7 \%$ & $2 \%$ \\
\hline 151 & 100 \\
\hline
\end{tabular}

(a) Survey Research Center (question 13, 1984).

(b) Hall and Associates (question 19, 1984). 
II. SURVEY OF EXISTING NONFEDERAL RESIDENTIAL RETROFIT PROGRAMS 
Federal dollars provided by the WAP and LIHEAP programs help to weatherize the homes of thousands of low-income households every year. However, a number of additional types of low-income residential retrofit programs have also sprung up in every state in the nation. The DOE asked PNL to conduct a survey of a varied sample of these programs to identify innovative ways that states, cities, utilities, and private and nonprofit groups have collectively or individually developed to supplement the WAP/LIHEAP activities. The programs identified were examined to assess their motivation, sources of support, weatherization goals and apparent sustainability. This portion of the handbook describes the findings of that survey. 



\section{EXISTING NONFEDERAL LOW-INCOME RESIDENTIAL RETROFITTING}

This study has identified 50 programs that provide weatherization assistance to low-income residents without federal funding (see Table 1). The organizations that sponsor these programs include utility companies, nonprofit groups, state offices and social service agencies (most often involved with business spin-offs). Of course, these organizations have many differences that make them unique. These differences include the motivation for offering programs (i.e., utility companies' reasons are much different from nonprofits and state offices). Size and internal structure also dictate the types of weatherization programs that are offered. Because of the differences in organizations and the resulting differences in the programs that are offered, programs are categorized in this handbook according to the type of sponsoring organization.

In some instances, a variety of organizations are involved in partnerships to administer a low-income weatherization program. In this handbook, the program was categorized by the type of organization that provides the majority of support to the program in terms of administration, funding or other efforts. For example, in some cases a nonprofit organization has been set up by a utility to satisfy its Residential Conservation Service (RCS) requirements and to administer its low-income residential retrofit program. In that case the program would be categorized as a utility program, not a nonprofit program, because the utility plays the primary support role.

The programs that were identified by PNL are discussed in this section of the handbook and are categorized as utility programs, nonprofit programs, state programs, and business spin-offs. More detailed descriptions of these programs and their contact addresses can be found in Appendix $A$.

\section{UTILITY PROGRAMS}

Fifteen of the programs reviewed in the survey are sponsored by utilities and are supported internally or in part by state, private, or nonprofit sources. These programs have been in operation from less than one year to nine years, with the majority in operation less than three years.

The most common types of weatherization services offered by utilities to low-income residents include home energy audits (often required as part of the RCS), and anti-infiltration measures, which include weatherstripping, caulking, broken glass replacement, insulation, door sweeps, and window plastic. Many programs also offer other minor home repairs if they are needed for weatherization.

Where Does The Money Come From?

Utilities have traditionally supported their weatherization programs through several different methods. These methods include increases in their rate base, customer donations, grants obtained through government entities, and internal funds such as stockholders' equity. The amount of funding provided 
TABLE 1. Low-Income Weatherization and Related Programs

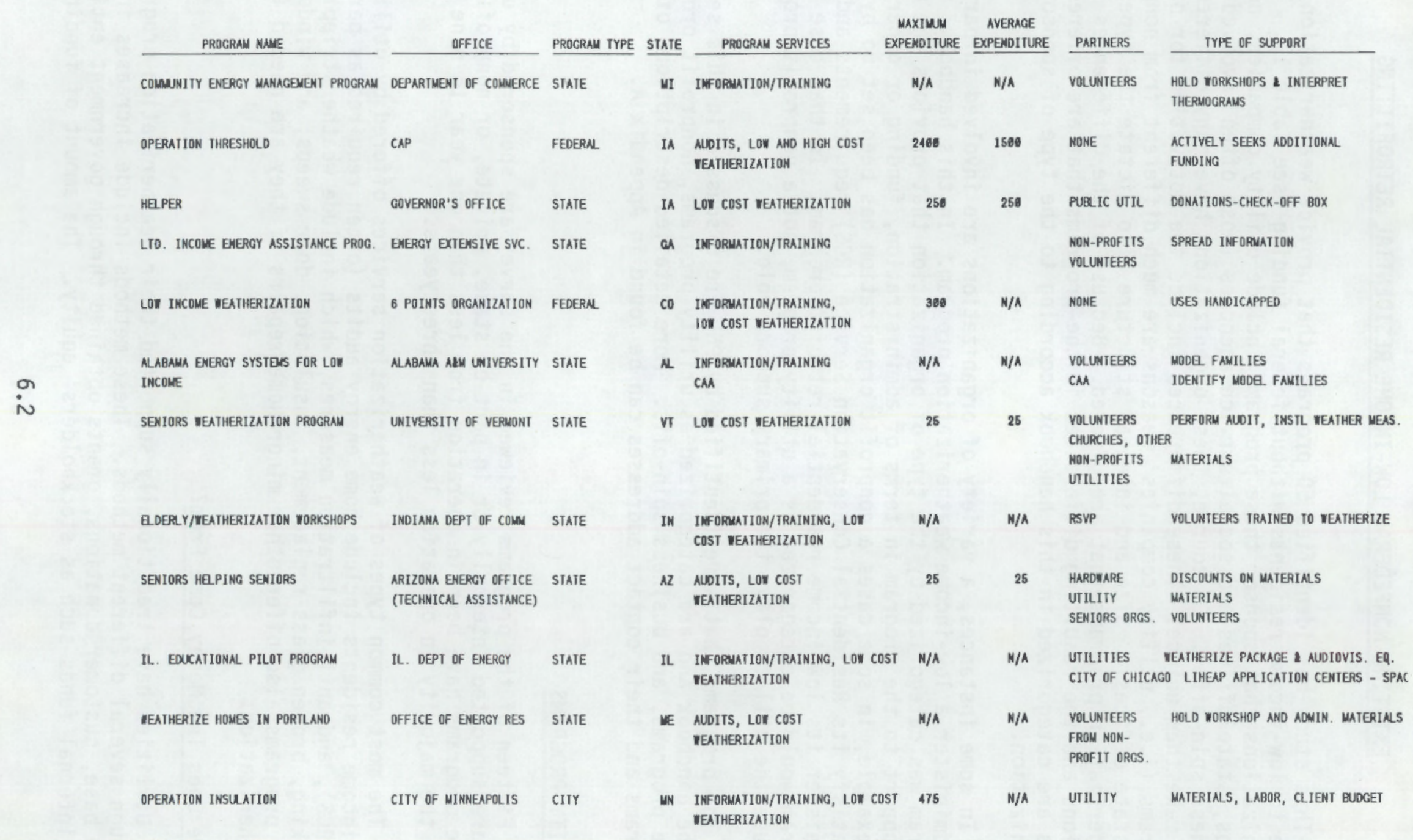




\section{TABLE 1. (contd)}

\begin{tabular}{|c|c|c|c|c|c|c|c|c|c|}
\hline PROGRAM NALE & OFFICE & PROGRAM TYPE & STATE & PROGRAM SERYICES & & $\begin{array}{l}\text { NAXIMUM } \\
\text { PEADITURE E }\end{array}$ & $\begin{array}{l}\text { AVERACE } \\
\text { EXPEAOITURE }\end{array}$ & PARIMERS & TYPE OF SUPPORT \\
\hline CAPACIIY BUILDING FOR EMERGY CONSER & AMOCO FOUNOATION & NON-PROFIT & OH & AUDIIS & & $N / A$ & $1 \mathrm{k}$ & $\begin{array}{l}\text { IAP, LIEAP } \\
\text { CORPORATION }\end{array}$ & $\begin{array}{l}\text { FUNDING } \\
\text { FUNDING }\end{array}$ \\
\hline CENTRALIA AREA ENERGY ASSISTAMCE & MINISTERINL ALLIANCE & NON-PROFII & IL & LOU COST WEATHERIZAIION & & $N / A$ & W/A & $\begin{array}{l}\text { CHURCHES } \\
\text { FDUNDATION }\end{array}$ & $\begin{array}{l}\text { VOLUNIEERS } \\
\text { FUNDING }\end{array}$ \\
\hline & & & & & & 1280 & 600 & UTILIHIES & NODIIS \\
\hline ENERGY ASSISTANCE FDUNDATION & ILLINOIS POWER COMPANY & NON-PROFIT & It. & MONIS & & 1800 & 750 & $\begin{array}{l}\text { UTILITY } \\
\text { UIILITY CUSI. }\end{array}$ & $\begin{array}{l}\text { AUDIIS, FUNDING } \\
\text { FUNOING }\end{array}$ \\
\hline CAUKATHON & VESTSIDE ENERGY COOP & NON-PROFIT & CB & LON COST WEATHERIZATION & & $N / A$ & $n / A$ & CHURCHES & YOLUNTEERS \\
\hline GDOD SAMARITANS & GOOD SAMARITANS & NON-PROFIT & TN & LON COST VEATHERIZAIION & & 260 & 150 & $\begin{array}{l}\text { CHURCHES } \\
\text { TVA }\end{array}$ & $\begin{array}{l}\text { VOLUNIEERS } \\
\text { TRAINING }\end{array}$ \\
\hline SENIOR ENERGY SAYERS & N. CAROLINA NLTER. & NON-PROFIT & MC & $\begin{array}{l}\text { IFFORAATION/IRAINING, LOW } \\
\text { WEATHERIZATION }\end{array}$ & $\cos \mathrm{T}$ & N/A & 76 & $\begin{array}{l}\text { SEMIORS } \\
\text { MON-PROFII ORG } \\
\text { MEMBER UTIL. }\end{array}$ & $\begin{array}{l}\text { PROMOTIONAL MATERIALS } \\
\text { VOLUNIEERS } \\
\text { FUNDING }\end{array}$ \\
\hline WORCESTER LABOR CORP. & NORCESTER LABOR COP & NON-PROFIT & m & $\begin{array}{l}\text { INFORMATION/TRAINING, LOW } \\
\text { TEATHERIZAIION }\end{array}$ & $\operatorname{cosT}$ & VARYS & VARYS & NON-PROFII & VOLUNTEERS \\
\hline METROPOLITAN EMERGY INFORMATION & METRO ENERGY INFOR. & NON-PROFIT & no & INFOFUATION/TRAINING & & YARYS & VARYS & $\begin{array}{l}\text { BUSINESSES } \\
\text { SERVICE ORGS. }\end{array}$ & $\begin{array}{l}\text { FUNDING } \\
\text { VOLUNTEERS }\end{array}$ \\
\hline ENERGY RESQURCE CORP & ENERGY RESQURCE CENT & NON-PROFIT & MN & AUDITS, LORNS & & $\$ 586 B$ LOAN & $\$ 3000$ LOAR & & \\
\hline BARNRAISING & WESTSIDE ENERGY CORP & NON-PROFIT & Co & $\begin{array}{l}\text { IMFORUATION/TRAINING, LOY } \\
\text { WEKTHERIZATION }\end{array}$ & cost & $N / A$ & N/A & CHURCHES & VOLUNIEERS \\
\hline CHRISTIANS FOR URBAN JUSIICE & CIRIST. FOR URBAN JUST. & NON-PROFIT & un & INFORMATION/IRAINING & & N/A & $N / A$ & CHURCHES & FUNDING \\
\hline PEOPLE'S NATURAL GAS WEATHERIZATION & PEOPLE'S NATURAL GAS & UTILIIYY & IA & $\begin{array}{l}\text { INFOFMATION/TRAINING, LOW } \\
\text { WEATHERIZAIION }\end{array}$ & $\cos \mathrm{T}$ & 2460 & 1296 & $\begin{array}{l}\text { PUQRIC } \\
\text { DONAIIONS }\end{array}$ & $\begin{array}{l}\text { DORATE TO UIILITY CHECK- } \\
\text { BOX }\end{array}$ \\
\hline SOUTHERN CONMECIICUT ACTION TEAM & UNITED ILLLWIHATING & UIILITY & CI & $\begin{array}{l}\text { INFORUAIION/TRAINING, LOW } \\
\text { TEATHERIZATION }\end{array}$ & $\cos \mathrm{T}$ & NOME & 930 & CAA & SUBCONTRACT \\
\hline
\end{tabular}


TABLE 1. (contd)

\begin{tabular}{|c|c|c|c|c|c|c|c|c|}
\hline Progran HAME & OFFICE & PROGRAM TYPE & STATE & PROGRAM SERVICES & $\begin{array}{l}\text { MAXIMUN } \\
\text { EXPENDITURE }\end{array}$ & $\begin{array}{c}\text { AVERAGE } \\
\text { EXPENOITURE }\end{array}$ & PARINERS & IYPE OF SUPPORT \\
\hline Q.DERS HEPING RODERS & H.E. UTILIHES & UTHITY & CT & $\begin{array}{l}\text { AUDITS, LOW \& HIGH COST } \\
\text { WEATHERIZATION }\end{array}$ & NONE & 130 & CAA & SUBCONTRACT \\
\hline DIRECT IEATHERIZAIION & SAN DIEGO GAS & UIILITY & $\mathrm{CA}$ & $\begin{array}{l}\text { LOW COST WEATHERIZATION } \\
\text { WEATHERSIRIP, EIC. }\end{array}$ & $N / A$ & 425 & $\mathrm{~N} / \mathrm{A}$ & $N / A$ \\
\hline ARKANSAS GAS C8. & ARKANSAS GAS CO. & UILITIY & AR & $\begin{array}{l}\text { INFOFAATION/TRAINING, LOW } \\
\text { COST YEATHERIZATION }\end{array}$ & NONE & 100 & $\mathrm{~N} / \mathrm{A}$ & $\mathrm{N} / \mathrm{A}$ \\
\hline OPERATIOK ASSIST & ALABMMA GAS CO. & UTILITY & N. & $\begin{array}{l}\text { AUDITS, INFORAAIION/IRAINING } \\
\text { WEATHERIZATION }\end{array}$ & $N / A$ & $\mathrm{~N} / \mathrm{A}$ & STAIE EMP. & SUESIOIZE MORKERS \\
\hline RHOOE ISLANDERS SAVING ENERGY (RISE) & RISE & UIILITY & RI & IMFORAMIION/TRAINING & M/A & N/A & UTILIIIES & FUNDING \\
\hline PROJECT 2800 & NASHYILLE QEET. SER. & UILILIY & TN & LOT COST MEATHERIZATION & NONE & VARYS & SENIORS & HELP LOCAIE LOWI INCOME RESIDENTS \\
\hline CARES & CHUGACH BEE. KSSO. & UHILITY & AK & NOITS, LOW COST WEATHERIZ. & LOAN & LOAN & $\mathrm{N} / \mathrm{A}$ & $\mathbf{N} / \mathbf{A}$ \\
\hline SOUTHERN CALIFORNIA EDISON & SQUTHERN CNL. EDIS. & UTILITY & CA & AUDITS, LOW COST YEATHERIZ. & MOME & $\boldsymbol{P}$ & $\mathrm{CAA}$ & $\begin{array}{l}\text { IDENIIFY RESIDENTS } \\
\text { SUBCONTRACT }\end{array}$ \\
\hline NEATHERIZE BOSTOK & CITY of BOSION & UIILITY & $\mathrm{m}$ & $\begin{array}{l}\text { LOW COST NEATHERIZATIOK, } \\
\text { ALOITS, LOANS }\end{array}$ & MIKIMAN & NINIUN & VOLUNIEERS & $\begin{array}{l}\text { WORD-OF-MOUTH a } \\
\text { WORKSHOPS }\end{array}$ \\
\hline IINTER BUTION-UP & BALTIMORE GAS I EEEC. & UTILITY & MD & $\begin{array}{l}\text { INFORMATION/TRAINING, LOW COST } \\
\text { WEATHERIZATION, AUDIIS, }\end{array}$ & T & 35 & $\begin{array}{l}\text { HEICHBORHOOD } \\
\text { NEN-PROFIIS }\end{array}$ & $\begin{array}{l}\text { OISTRIBUIE KITS, HOLD } \\
\text { TRAINING WORKSHOPS }\end{array}$ \\
\hline HAND IN HAND & OKLAHOMA CAS I EEE. & UTLLITY & OK & $\begin{array}{l}\text { INFDRMATION/TRAINING, LOW COST } \\
\text { WEATHERIZATION }\end{array}$ & 5ø0 & 200 & SENIORS & $\begin{array}{l}\text { CONIRACT MEATHERIZATION } \\
\text { WORK }\end{array}$ \\
\hline GAS VEATHERIZATION PROGRAM & WISCONSIN POWER & UIILITY & II & AUDITS, LON COST WEATHERIZ. & $2 \mathrm{~K}$ & 85 & $N / A$ & $\mathrm{~N} / \mathrm{A}$ \\
\hline BALTWDRE BEC. NLLIANCE PROGRAM & $\begin{array}{l}\text { BALTIMORE GAS } 2 \text { B.EC. } \\
\text { BALTIMORE MAIERIALS }\end{array}$ & $\begin{array}{l}\text { UTILITY } \\
\text { s, SUPERYISIOH }\end{array}$ & MD & HIGH COST MERTHERIZATION & 406 & $\mathrm{R} / \mathrm{A}$ & CIIY of & TECHNICAL ASSISTANCE, \\
\hline
\end{tabular}


by utilities and other sources varies depending on the type of weatherization services offered, the number of homes to be weatherized and the amount of assistance the utility receives from other sources. Several of the utility programs identified for this handbook were mandated by their state PUC to provide weatherization services to low-income customers (see Table 1). These utilities are normally able to recover their costs through their rate base.

Public donations are often solicited through utility bill customer checkoff boxes and have been used by many utilities to gain financial support. These donations cover at least part of the utility's weatherization program costs; however, most utilities do not rely entirely on this funding source to cover all of their low-income weatherization efforts, but rather to supplement other funding sources. For example, People's Natural Gas Company in Iowa obtains about $30 \%$ of its weatherization program funding through customer utility bill check-off donations. The utility weatherizes about 150 low-income homes per year.

Utility companies often submit proposals to federal and state offices in an attempt to gain funding for weatherization programs. State and federal assistance can also come in other forms, such as subsidized workers. In the case of Alabama Gas Company's Operation Assist Program, the Alabama State Employment office hired low-income youths to perform weatherization work for Alabama Gas Company. The Employment office provided the utility with tax incentives for employing these workers for the summer of 1985 . This program proved to be successful for both Alabama Gas Company in weatherizing homes and for the state-subsidized workers, who gained work experience. Alabama Gas Company has submitted a request to provide the same program to low-income customers for the summer of 1986 .

Many utilities use internal funds, at least to some degree, to assist their needy customers. This assistance, however, does not always come in the form of weatherization. Some utilities choose to provide fuel assistance funds to pay the bills of needy customers and planning assistance for budgeting fuel bills of needy customers.

Who's Eligible for Utility Programs?

Many utility programs give first priority to senior citizens or handicapped; 5 of the 14 utility programs identified for this handbook specifically targeted these groups. Ten of the programs use the federal income eligibility requirements developed by the LIHEAP and WAP ( $125 \%$ and $150 \%$ of federal poverty level, respectively) to identify potential recipients. Most utility programs have fairly flexible income eligibility requirements and make special considerations for customers whom the utility feels are needy.

What Sort of Networking/Partnerships Exist?

In some cases, utilities have combined efforts with government agencies and nonprofit groups to help solve energy-related problems facing the poor. Some utilities have informal relationships with other groups that assist the 
utility in identifying and screening residents, while other utilities have helped establish formalized panels or committees made up of representatives from the utility and other concerned groups.

Utilities and Social Service Agencies

Utilities have found that networking with local community action agencies is an effective way to identify potential weatherization recipients because the utilities are able to use lists of clients waiting for federal weatherization assistance. In fact, most of the utility programs that PNL identified worked in conjunction with community action agencies at least to some degree. By working with local agencies, the utilities reduce the chances of duplicating the efforts of government programs and supplement federal weatherization programs. Another common method for identifying low-income participants is the utility's fuel assistance lists.

Utilities often award weatherization subcontracts to local social service agencies, which bid on the work along with other private contractors. Social service agencies are familiar with the target group of recipients, whereas most private contractors have had experience with higher-income groups. These agencies also have the advantage of offering the utility a mechanism for identifying potential recipients.

As federal weatherization funds have diminished, some social service agencies and other nonprofit organizations have increased their amount of utility subcontracts. For example, the Lutheran Housing Corporation (LHC) in Ohio is a nonprofit organization that has traditionally administered federal weatherization programs that were supplemented through foundation grants. Recently, both LHC's federal monies and foundation grants have been reduced. To continue to provide weatherization assistance to low-income residents in its community, LHC is looking to utilities for weatherization subcontracts. As of yet, LHC has not secured any weatherization contracts, but expects to do so in the future.

\section{Partnerships Between Utilities and State Offices}

A more formalized effort to develop networks/partnerships has taken place in Connecticut. The state of Connecticut, in conjunction with utilities, community action agencies and nonprofit groups, has organized the Governor's Advisory Committee to centralize the efforts and interaction between those in the state concerned with energy-related problems facing low-income residents. The committee includes representatives from state offices, utilities, community action agencies, and other nonprofit groups that have consistent goals but usually different ideas about how these goals can/should be met. This committee allows these organizations to express their personal objectives and to hear the views of others on a regular basis. According to a representative from New Opportunities for Waterburg, a community action agency involved in the committee's development, organizing the committee required hard work and coordination by all involved, but the benefits of better understanding and cooperation among all involved have been well worth it. 
NONPROFIT PROGRAMS

Private and nonprofit organizations sponsoring low-income weatherization programs were of interest in PNL's search for innovative programs that are supported at least in part by nonfederal funding or efforts. Six nonprofit organizations were identified that had undertaken programs to help low-income residents weatherize their homes. These nonprofit organizations were fairly small and helped low-income residents in their own community. Relatively few of the private and nonprofit programs identified fit into this section of the handbook because nonprofit groups are more often involved in helping implement other programs set up by utilities or state and city governments. PNL staff did not find any private, for-profit organizations or companies that sponsored its own low-income weatherization program; however, some nonprofits do support programs sponsored by other groups through contributions of funds and materials.

Typical Services Offered by Nonprofit Organizations

The types of weatherization services offered by the nonprofit organizations differed from those offered by other types of organizations such as utilities and state or city governments. These differences are mainly due to the more limited resources of the smaller nonprofit organizations. The nonprofit programs identified offered strictly low-cost weatherization measures that dealt with air-infiltration problems, whereas utilities and government-sponsored programs many times offered more extensive weatherization services, such as structural repairs and furnace retrofits. Nonprofits also provided low-income residents with weatherization-related information and/or training, as did many of the state programs. Two nonprofit organizations provided low-income residents with free energy audits and one offered state low-cost loans (see Table 1).

\section{Why Do Nonprofits Become Involved In Low-Income Residential Retrofit?}

The background and development of the nonprofit organizations identified by PNL staff explain in part their motivation for becoming involved in lowincome weatherization programs. A few nonprofit programs were developed for philanthropic reasons as a means to help the poor solve their energy-related problems. The development and success (in terms of weatherizing low-income residences without federal monies) of these programs depended on the commitment of a few determined individuals. Another program was developed specifically for assisting low-income residents to weatherize their homes; however, most other nonprofit organizations have a more general set of goals and are involved with several assistance programs for the poor--not just weatherization. Few nonprofit organizations have the expertise, motivation or desire to start their own weatherization program. Also, there is usually an already established program that they can become involved with in the area.

Development of a partnership with a larger, established low-income weatherization program offers the nonprofit organizations several benefits. In a partnership, the nonprofits can donate their services on an "as available" basis and do not have to worry about the administrative aspects of the weatherization program. 
Examples of Programs Supported Mainly by Nonprofits

The Good Samaritans program was developed by a concerned citizen as a way to provide weatherization services to low-income residents in Cumberland County, Tennessee. The developers and other volunteers recruited area residents (mostly from churches) to help weatherize homes. The program was also able to gain material discounts from area manufacturers and assistance in training volunteers from Tennessee Valley Authority (TVA).

Capacity Building For Energy Conservation, in Chicago, Illinois, initially funded by the AMOCO foundation and later by the local community organizations that helped develop the program, is an example of a low-income weatherization program developed and supported by nonprofit groups. The local community groups provide weatherization services to low-income residents following a plan they developed with the assistance of the AMOCO foundation. This program relies on volunteers and donated funding. This program is described in more detail later in the next chapter.

How Are Nonprofit Groups Normally Involved?

As mentioned previously, nonprofit organizations rarely have the expertise to develop and implement their own weatherization program, so they become involved in some other established program that will provide them with weatherization training, administrative assistance, and usually some funding. Examples of nonprofit involvement in utility and state programs were mentioned earlier in this handbook.

Nonprofits' contributions to a program normally are in the form of donating their own group's time or recruiting the support of others in the community. This support may be in the form of volunteers, funds, and materials needed to implement a larger program at the community level. These groups are often important sources for referrals of low-income residents because of their established networks with the community.

What Role Do Large Nonprofit Organizations Play?

Most larger nonprofit organizations, such as the United Way and the National Urban League, do not have their own low-income weatherization programs. Rather, they donate funds to other groups that administer weatherization services such as local community groups and some of their own affiliates. For example, the Pinellas County Urban League (PCUL) in St. Petersburg, Florida, contracts with the DOE to weatherize low-income homes under the WAP program. PCUL also receives supplemental funding from the National Urban League and the United Way in order to weatherize more homes.

\section{STATE PROGRAMS}

The DOE does not expect current federal efforts and funds to be adequate to meet the energy improvement needs of low-income residents. To maintain the same level of weatherization services currently provided by federal weatherization programs, alternative sources for providing services are needed. For 
this handbook, nine state programs and one city program were identified as being designed to deliver weatherization services to low-income households without federal funding. These programs involved the cooperation and assistance of nonprofit organizations, utilities, and other state offices.

History of State Weatherization Involvements

Since the 1970 s, federal weatherization programs operating through state offices have become the principle means for providing weatherization assistance to low-income residents throughout the United States. The federal WAP provides states with grants to enable community agencies to install weatherization measures in homes occupied by low-income residents, particularly the elderly and handicapped.

According to the U.S. General Accounting Office, weatherization of all currently eligible homes will not occur until well into the 21 st century if current federal and state policies, procedures, and funding continue at their present rates. Since 1982, because of the slow progress of weatherization and the realization that it makes more sense to reduce rather than subsidize energy consumption, states have been able to direct up to $15 \%$ of their LIHEAP funds to supplement WAP. The remaining $85 \%$ of LIHEAP funds are still appropriated for paying the energy bills of low-income residents. Traditionally, both WAP and LIHEAP have been administered by the states and distributed through local social service agencies.

Both the WAP and LIHEAP programs have encountered budget reductions, and state and federal weatherization administrators generally feel that these federal monies will diminish in the future. However, the speed at which they might decline is not known. To date, however, states still rely heavily on these federal weatherization monies and have not developed alternative sources of funding to match the same level of weatherization support now available through WAP and LIHEAP programs. State and city offices provide block grants to weatherize specific communities, but these monies are not comparable in scale to federal efforts.

\section{What State Efforts Go Beyond WAP and LIHEAP?}

The state-sponsored low-income residential retrofit programs that derive most of their resources from nonfederal sources are listed in Table 1 . States also have provided support on a smaller scale to utilities and nonprofit groups, as mentioned earlier in this handbook. Most of the state programs identified in this handbook involve formal or informal partnerships with utilities and community-based organizations, provide low-cost weatherization, and are administered at the local level. Formal partnerships involve an agreement among the parties that specifies a time frame and level of support from each, while an informal partnership depends on the parties' cooperation without any set agreements concerning levels of involvement. 


\section{The States' Role in Partnerships}

States' contributions to the low-income weatherization programs normally have come in the form of administration and/or development of a weatherization program model and technical assistance. The Senior Energy Savers program, co-sponsored by the Arizona Energy Office, the Governor's Advisory Council on Aging, and the Southwest Gas Corporation, is an example of a state-developed and co-administered low-income residential weatherization program. The Seniors program provides elderly low-income homeowners with free home energy audits and installation of up to $\$ 25$ of weatherization measures. These weatherization measures are installed by community volunteers who are recruited by nonprofit community groups (usually churches). The Arizona Energy office provides technical information, program administration, and training for the volunteers; Southwest Gas Corporation contributes most of the funding; the Governor's Advisory Council encourages businesses to provide discounts on more extensive weatherization supplies to senior citizens; and senior citizen organizations recruit volunteers to install the weatherization measures. Another similar state program is HELPER, coordinated by the Governor's office in Iowa.

Services offered by State Programs

The state low-income home conservation programs examined in this handbook do not provide as extensive weatherization services to low-income residents as do those provided by federal programs or most utility programs. Most of these state programs provide information to low-income residents on low- or no-cost measures that residents could install themselves, often accompanied by a take-home weatherization packet of materials worth about $\$ 25$. Some of the state programs also provide installation of weatherizing materials, as in the Senior Energy Savers program mentioned above.

Typically, these states' motivation for developing programs is to supplement the WAP program and to assist residents who are too far down on federal assistance lists to receive any service for some time. Elderly and handicapped individuals are often targeted in these state programs because these groups respond less often to federal weatherization program recruiting techniques than do other low-income groups, yet they are often in great need of assistance.

The Senior Energy Savers program mentioned above, the Seniors Weatherization Workshop in Vermont, and Weatherize Homes in Portland are all examples of state low-income weatherization programs that provide information and/or services through workshops held by nonprofit groups.

State Coordination with Social Service Agencies

State programs, like utility and nonprofit programs, often rely on LIHEAP and WAP eligibility lists from community action agencies to identify potential recipients for weatherization services. States have also relied on these agencies assistance in various ways, including identifying potential volunteers and distributing weatherization and informational materials to low-income residents. For example, in a 1979 state-sponsored pilot project, Alabama A\&M University coordinated with local community action agencies to identify potential volunteers. In their Alabama Energy Systems for Low-Income Residents 
Program, the university coordinated with local community action agencies, which identified potential "model families" (community volunteers) to deliver conservation/weatherization information to low-income residents. Because community action agencies have experience with low-income families, they were able to help identify people in the community who had leadership skills and who were well respected by their peers.

Another example of how states coordinate with community action agencies to provide energy-efficiency improvement assistance is the Educational Pilot Program, sponsored by the Illinois Department of Energy in cooperation with the city of Chicago and two utility companies. This program is intended to supplement the financial assistance portion of LIHEAP. When applicants arrive to apply for the program, they are first shown a ten-minute informational slide show on low-cost conservation measures and are given a free packet of weatherization materials.

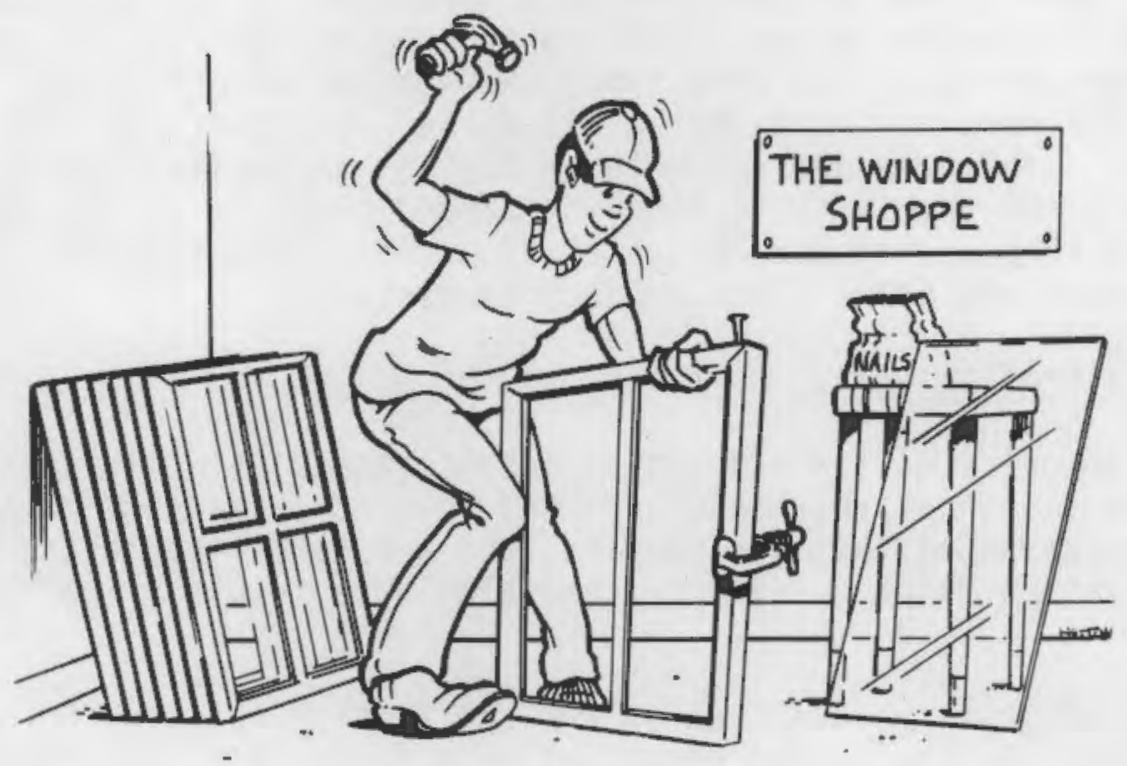

\section{BUSINESS SPIN-OFFS}

The search for increased or alternative revenues to provide weatherization services has led several local community action agencies and other nonprofit groups into the area of business spin-offs. (a) These are businesses that produce services and/or products, the revenues from which are used to support the parent organization's energy conservation program. In searching for innovative low-income weatherization programs for this handbook, nine organizations were identified as developing some sort of business spin-off;

(a) The DOE has recognized the promise implied by the spin-off concept by awarding business development grants through the WAP. These grants are now under way. Further information is available from the WAP contact person in the DOE support offices. 
most were weatherization-related. The types of business spin-offs ranged from the fabrication of wooden storm windows to a thrift shop where elderly residents of a community donate time and unwanted possessions to a "worthwhile cause." The nine business spin-offs are listed in Table 2.

Some of these spin-off businesses produce items that are used only within the agency's weatherization program to supplement federal dollars for purchasing materials, while other spin-offs market their products to other individuals or businesses in the community. The internal and environmental (such as available discretionary funds and weatherization material needs) circumstances surrounding the decision to spin-off a business and the type of business spinoff differed among programs.

Profit was sometimes, but not always, the motive for starting the business. For example, one rural Oregon agency, Blue Mountain Development Council, was faced with losing its only supplier of storm windows and decided to purchase the company when it was offered for sale. Factors in the purchase included its affordable purchase price, and a co-manager of the company agreeing to stay on after the sale. In this case, the agency had not specifically intended to start a business spin-off, but a situation arose that made the possibility more viable. Other reasons encountered for an agency starting business spinoffs included the inability to find the needed products in the private sector, and a way to keep agency workers on staff during slack time (so the agency and its workers would build the product themselves).

Where Do The Profits Go?

Most community action and social service agencies administer several low-income assistance programs other than low-income weatherization. Therefore, there is no guarantee that the profits from a spin-off business, even if it is weatherization-related, will be channeled back into the weatherizing activities.

In the programs encountered by PNL staff, profits from the spin-offs were usually allocated by the organization's Board of Directors to programs where the most need existed at the time. For example, a Meals on Wheels program that had limited funds might be considered to have greater need than the weatherization program in the middle of summer. Also, because most of the programs encountered had only been in operation for a short period of time, any excess funds were often channeled back into the business or used to pay back loans, or there may have been no profits to be used by any program. Most of the program managers interviewed expected their investment in the business to be paid back in less than three years.

How Are Spin-0ffs Started?

Business spin-offs identified in this handbook basically were undertaken in one of three ways: 1) acquisition of an existing business, 2) development of an in-house business on a small scale, and 3) start-up of an independent business venture. The most popular among these three spin-off options was the in-house development on a small scale. This option allows the social service agency to "test the water" before they take the big financial plunge. 
TABLE 2. Spin-0ff Businesses

\begin{tabular}{|c|c|c|c|c|c|c|c|c|c|}
\hline SIAIE & PROCRAN/ACENCY & $\begin{array}{l}\text { TYPE OF PRODUCT } \\
\text { OR SEEYICE }\end{array}$ & $\begin{array}{c}\text { WHEM } \\
\text { SIRRTED } \\
\end{array}$ & $\begin{array}{l}\text { REASON FOR } \\
\text { SIARIINO }\end{array}$ & $\begin{array}{l}\text { ANNUAL } \\
\text { PROFIIII } \\
\text { SAYINGS } \\
\text { PER UNII } \\
\end{array}$ & $\begin{array}{l}\text { WHERE PROFITS, } \\
\text { SAVIMGS } \\
\text { CHANIKBED }\end{array}$ & $\begin{array}{l}\text { HOW MARKETED } \\
\text { TO PRIVATE SECTOR }\end{array}$ & $\begin{array}{l}\text { WHY NOT MARKET } \\
\text { TO PRIVATE SECTOR }\end{array}$ & NDVICE \\
\hline$A R$ & East Central CAA & Storm windows & 1984 & $\begin{array}{l}\text { Supplement A fow to prirate } \\
\text { materials sector } \\
\text { (federal \&) }\end{array}$ & 328,668 & $\begin{array}{l}\text { Other } \\
\text { programs }\end{array}$ & Word of wouth oniy & $\begin{array}{l}\text { Might put other } \\
\text { businesses out of } \\
\text { business }\end{array}$ & $\begin{array}{l}\text { Initially used } \\
\text { subsidized } \\
\text { workers--CETA }\end{array}$ \\
\hline$A R$ & $\begin{array}{l}\text { Universal } \\
\text { Development }\end{array}$ & $\begin{array}{l}\text { Thermo doors/ } \\
\text { windows }\end{array}$ & 1977 & $\begin{array}{l}\text { Supplement Mone } \\
\text { materials } \\
\text { (federal s). } \\
\text { couldn't } \\
\text { afford } \\
\text { ready mades }\end{array}$ & $\begin{array}{l}\text { Save } \$ 25 \\
\text { per window }\end{array}$ & $\begin{array}{l}\text { Neather- } \\
\text { ization }\end{array}$ & & Too much work & $\begin{array}{l}\text { Use subsidized } \\
\text { workers--green } \\
\text { thum }\end{array}$ \\
\hline AR & $\begin{array}{l}\text { Office of } \\
\text { Human Concern }\end{array}$ & Storn panels & 1978 & $\begin{array}{l}\text { Supplenent Mono } \\
\text { (federal s), } \\
\text { keep workers } \\
\text { on staff, new } \\
\text { type, savings }\end{array}$ & $\begin{array}{l}\text { Save \$19- } \\
\text { \$15 per } \\
\text { window }\end{array}$ & $\begin{array}{l}\text { Veather- } \\
\text { ization }\end{array}$ & & Liability & \\
\hline$A R$ & $\begin{array}{l}\text { Office of } \\
\text { Human Concern }\end{array}$ & Thrift shop & 1984 & To privato sector & $\mathbf{8 8 5 , 6 0 0}$ & $\begin{array}{l}\text { Elderly } \\
\text { prograns }\end{array}$ & $\begin{array}{l}\text { Media-cover stories } \\
\text { local adv. }\end{array}$ & & $\begin{array}{l}\text { Fit into } \\
\text { comeunity }\end{array}$ \\
\hline$A R$ & $\begin{array}{l}\text { Eronomic Dpportun. } \\
\text { Agency of VA } \\
\text { County }\end{array}$ & Storn windows & 1978 & $\begin{array}{l}\text { Supplement Fev to private sector } \\
\text { materials } \\
\text { (federal g), } \\
\text { keep workers } \\
\text { on staff, others } \\
\text { low quality a } \\
\text { tough to get }\end{array}$ & $\begin{array}{l}\text { 5ox savings } \\
\text { per window }\end{array}$ & $\begin{array}{l}\text { Weather- } \\
\text { ization }\end{array}$ & $\begin{array}{l}\text { Word of wouth } \\
\text { only }\end{array}$ & $\begin{array}{l}\text { Are now considering } \\
\text { broader marketing } \\
\text { strategy to private } \\
\text { sector }\end{array}$ & \\
\hline
\end{tabular}


TABLE 2. (contd)

\begin{tabular}{|c|c|c|c|c|c|c|c|c|c|c|}
\hline SIAIE & PRDGRAN/AGEICY & $\begin{array}{l}\text { TYPE OF PRODUCT } \\
\text { OR SERYICE }\end{array}$ & $\begin{array}{l}\text { WHEN } \\
\text { STARTED }\end{array}$ & $\begin{array}{c}\text { REASON FOR } \\
\text { STARTIMG }\end{array}$ & MUREES & $\begin{array}{l}\text { ANNUAL } \\
\text { PROFII/ } \\
\text { SAVINGS } \\
\text { PER UNIT } \\
\end{array}$ & $\begin{array}{l}\text { WHERE PROFITS/ } \\
\text { SAVINGS } \\
\text { CHAHNEED }\end{array}$ & $\begin{array}{l}\text { HOW MARKETED } \\
\text { TO PRIVATE SECTOR }\end{array}$ & $\begin{array}{l}\text { WHY NOT MARKET } \\
\text { TO PRIVATE SECTOR }\end{array}$ & AOVICE \\
\hline MINN & $\begin{array}{l}\text { Toyne- - Metropolitan } \\
\text { Comm Services Agcy }\end{array}$ & $\begin{array}{l}\text { Re-Nu Wood I } \\
\text { metal stripping }\end{array}$ & 1984 & $\begin{array}{l}\text { Prof it } \\
\text { (haven't } \\
\text { developed } \\
\text { yet) }\end{array}$ & To private sector & none & & $\begin{array}{l}\text { Haven't-waiting } \\
\text { for Ford contract }\end{array}$ & & \\
\hline MINN & $\begin{array}{l}\text { Wayne-Metropolitan } \\
\text { Coma Services Agcy }\end{array}$ & $\begin{array}{l}\text { Spring Tite } \\
\text { windows }\end{array}$ & 1985 & $\begin{array}{l}\text { Supplement } \\
\text { materials } \\
\text { (federal s). } \\
\text { profit, they } \\
\text { work better }\end{array}$ & $\begin{array}{l}\text { Private sector, other } \\
\text { wAP operators }\end{array}$ & 48x saving & $\begin{array}{l}\text { Weather- } \\
\text { ization }\end{array}$ & $\begin{array}{l}\text { Vill use sales } \\
\text { forco-to apts }\end{array}$ & & \\
\hline NY & $\begin{array}{l}\text { Syracuse Energy } \\
\text { Service Co. }\end{array}$ & $\begin{array}{l}\text { Conplete } \\
\text { weatherize } \\
\text { package }\end{array}$ & 1985 & Profit & $\begin{array}{l}\text { Privato sector } \\
\text { multi-unit housing }\end{array}$ & Too early & & Sales force & & \\
\hline OR & $\begin{array}{l}\text { Blue Mountain } \\
\text { Econ. Der. Council }\end{array}$ & $\begin{array}{l}\text { Stora windows } \\
\text { insulating }\end{array}$ & 1985 & $\begin{array}{l}\text { Supplenent P } \\
\text { materials } \\
\text { (federal 8), } \\
\text { supplier, } \\
\text { profit }\end{array}$ & Private sector & $\begin{array}{l}\text { Info not yet } \\
\text { arailable }\end{array}$ & $\begin{array}{l}\text { Distributed } \\
\text { among prgus, } \\
\text { back into } \\
\text { business }\end{array}$ & $\begin{array}{l}\text { Word of mouth, } \\
\text { yeliow pages }\end{array}$ & & \\
\hline HI & $\begin{array}{l}\text { Custom Hone } \\
\text { Improved Assoc }\end{array}$ & Windoms & 1983 & $\begin{array}{l}\text { Supplenent } \\
\text { eaterial } \\
\text { (federal s), }\end{array}$ & To other WAP & 226,000 & $\begin{array}{l}\text { Still } \\
\text { business }\end{array}$ & & May start-need a mgr & Need good $\mathrm{mgr}$ \\
\hline WI & Project Hone & Storm mindors & 1984 & $\begin{array}{l}\text { Supplenent p } \\
\text { materials } \\
\text { (federal s), } \\
\text { profit, employ } \\
\text { workers }\end{array}$ & $\begin{array}{l}\text { Prirate sector } \\
\text { oy }\end{array}$ & & $\begin{array}{l}\text { Veather- } \\
\text { ization }\end{array}$ & $\begin{array}{l}\text { Sell-mord of } \\
\text { wouth }\end{array}$ & & $\begin{array}{l}\text { Note: this } \\
\text { company was } \\
\text { purchased by the } \\
\text { workers }\end{array}$ \\
\hline
\end{tabular}


TABLE 2. (contd)

它

\begin{tabular}{|c|c|c|c|c|c|c|c|c|c|c|}
\hline SIAIE & PROGRN/AGENCY & $\begin{array}{l}\text { IYPE OF PRODUCT } \\
\text { OR SERYICE }\end{array}$ & $\begin{array}{l}\text { WHEN } \\
\text { STARTED }\end{array}$ & $\begin{array}{l}\text { REASON FOR } \\
\text { SIARIING }\end{array}$ & MARKEIS & $\begin{array}{l}\text { ANKUALL } \\
\text { PROFIII/ } \\
\text { SAVINGS } \\
\text { PER UNII }\end{array}$ & $\begin{array}{l}\text { WHERE PROFITS/ } \\
\text { SAVINGS } \\
\text { CHANNEED }\end{array}$ & $\begin{array}{l}\text { HOW MARKETED } \\
\text { TO PRIVATE SECTOR }\end{array}$ & $\begin{array}{l}\text { WHYY NOT UARKET } \\
\text { TO PRIVAFE SECTOR }\end{array}$ & ADVICE \\
\hline$M A$ & $\begin{array}{l}\text { Worcester Labor } \\
\text { Cooperative }\end{array}$ & $\begin{array}{l}\text { Complete } \\
\text { weatherization } \\
\text { services }\end{array}$ & 1982 & $\begin{array}{l}\text { To } \\
\text { cont inue } \\
\text { weatherization } \\
\text { for low-incoae } \\
\text { in place of } \\
\text { decreased govt }\end{array}$ & Private sector & $\begin{array}{l}\text { Is non- } \\
\text { prof it } \\
\text { business }\end{array}$ & $\begin{array}{l}\text { Back into } \\
\text { business }\end{array}$ & $\begin{array}{l}\text { Yellow pages } \\
\text { word of mouth }\end{array}$ & & $\begin{array}{l}\text { A business deneanor } \\
\text { and a good } \\
\text { relationship with } \\
\text { those whon you } \\
\text { network with }\end{array}$ \\
\hline
\end{tabular}


Often, this is the only way for an agency to accomplish a spin-off because there are no extra funds, or its Board of Directors will not approve such a venture. Staff from some of the social service agencies PNL staff contacted had made room in their own buildings for the spin-off business to cut costs. This also allowed the social service agency to better nurture the spin-off business and in a sense "hold their hand" while the business got started.

Only a few of the spin-off programs identified for this handbook had been purchased outright by agencies. This is probably because of the high price involved when purchasing a business, especially if it has been profitable. In addition, nonprofit agencies usually do not have the expertise required to go in and manage a for-profit business. It is also apparently difficult to find an established weatherization business that is affordable, profitable, and managed by someone who is willing to stay with the company--such as in the case of $A B C$ Weatherization Company, mentioned above.

PNL staff found that an independent business venture is the least likely way for a spin-off to begin because of the financial risk involved; however, many spin-offs have became an independent venture after being nurtured inhouse for a period of time.

\section{What Administrators Should Know About Social Service Agency Attitudes Toward} Spin-0ffs

To identify some of the advantages and some of the barriers to developing and operating business spin-offs from those responsible for them, PNL staff used two sources: PNL's conversations with agency officials, and insight gained from the Energy Related Economic Development Conference sponsored by the Illinois Department of Community Affairs on April 21-23, 1986. Some of the advantages seen by agencies in starting a for-profit business include:

- greater self-sufficiency

- more opportunities for employment

- more respectability from politicians

- possibility that staff may share in the profits

- possibly the only way to survive financially.

Some of the barriers seen by agencies in undertaking a for-profit business include:

- 1ack of start-up money (the biggest reason)

- the possibility of losing federal grant monies because of the legal questions associated with starting a for-profit business

- inability to attract qualified labor at a reasonable price

- organizational problems

- competition with established businesses

- increased responsibility and paperwork 
- lack of sufficient technical knowledge on how to start a business

- damage to the agency's public image as a nonprofit service organization

- inconsistencies with the agency's mission (i.e., programs developed to help the poor should not be involved in for-profit ventures)

- lack of incentives to take on the extra burden

- lack of "entrepreneurial" staff and the "savvy" to start a business.

These potential problems and barriers should be kept in mind if the development of business spin-offs is being contemplated as a way to supplement funds for weatherizing activities. 



\section{ASSESSMENT OF NONFEDERAL PROGRAMS}

In this chapter, a closer look is taken at the various residential retrofit efforts by identifying specific characteristics that have helped these programs to be successfu1. A "successful" nonfederal weatherization program is defined in this handbook as any effort that appears to be sustainable and that meets its program objectives (i.e., providing weatherization assistance to a specific group of low-income residents).

\section{WHAT MAKES RESIDENTIAL RETROFIT PROGRAMS WORK?}

Characteristics of nonfederal low-income residential retrofit efforts that were reviewed in the survey are listed in a matrix (Figure 1). These characteristics have been categorized into the following groups to help develop some generalizations about these programs and to help focus on key elements that appear to be important:

- motivation

- financial support (source and type)

- in-kind support (source and type)

- marketing

- success factors.

The programs that were identified in the survey were reviewed in terms of these characteristics. The results of the review are discussed in more detail in the following subsections for each characteristic.

\section{Principal Program Motivation}

A review of the weatherization programs identified in this resource guide shows that the programs were established for various reasons, including:

- mandated by state regulatory boards - Such programs are operated by several organizations, including state agencies and utilities. They were frequently very broad in terms of the targeted residents.

- philanthropic - Programs such as Tennessee's Good Samaritans are motivated by a desire to provide assistance to the needy.

- utility load leveling - A number of the utility programs are designed to help reduce peak demand for electricity.

- special needs - Some programs such as Vermont's Senior Weatherization focus exclusively on the needs of one segment of the population.

- public relations - Low-income programs sponsored by utilities can help enhance their public image. 



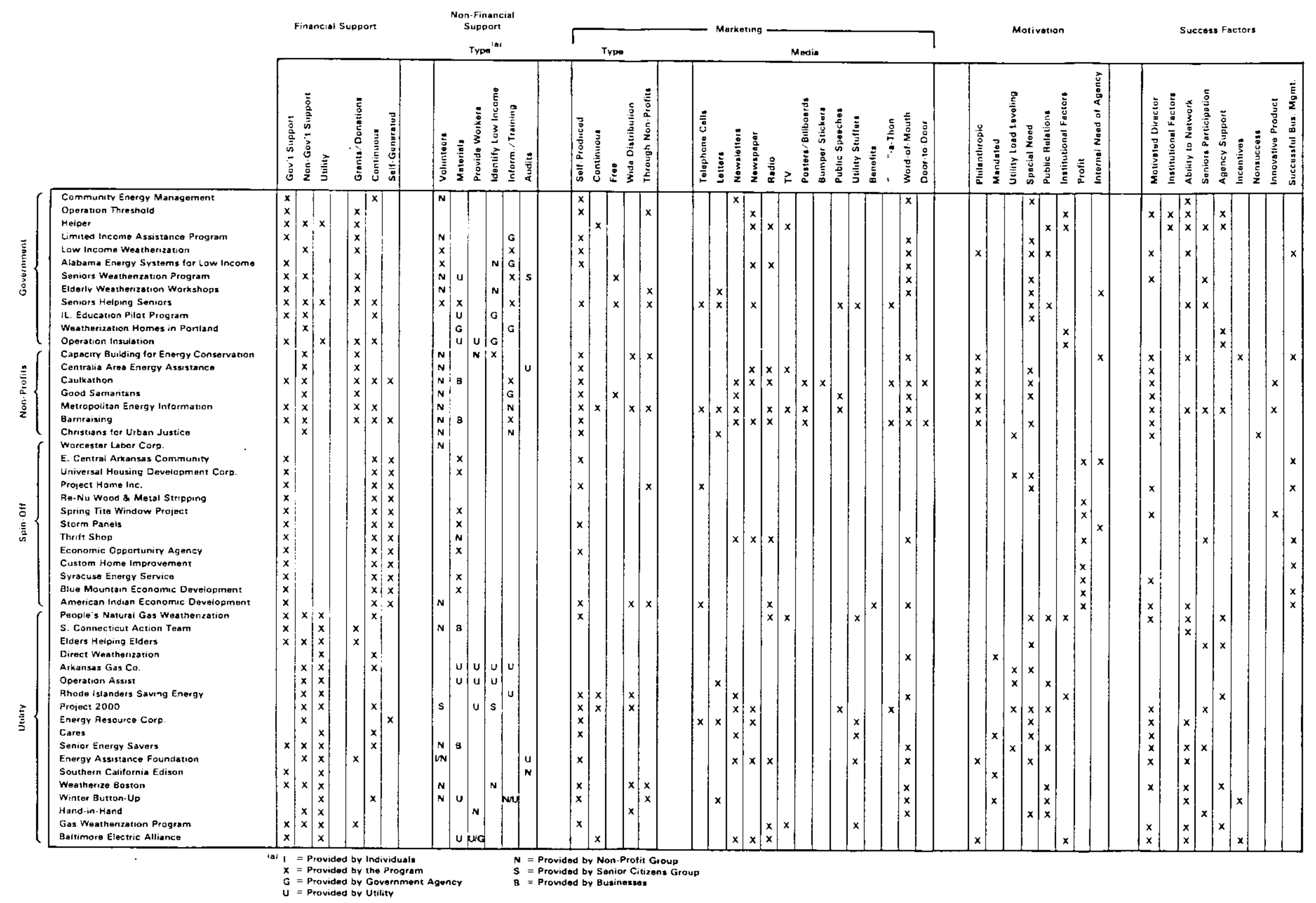



- institutional factors - Programs such as Rhode Islanders Saving Energy (RISE) develop out of a need to provide a unified source for weatherizing assistance.

- profit - Many of the business spin-off programs such as Blue Mountain are initiated as a way of making money to supplement their weatherization efforts.

- internal needs of agency - Programs such as Spring Tite start businesses because of the need for specialized weatherization materials.

Information presented in the matrix indicates that special needs are one of the principal motivating factors for establishing nonfederal residential retrofit programs. For example, some organizations or groups have identified local needs among certain groups, such as senior citizens and handicapped individuals. These groups may need weatherization assistance but may not meet the income criteria set by federal weatherization programs. If these individuals qualify under the federal low-income guidelines, they are usually referred to the appropriate government-funded programs.

Several of the utilities have started low-income weatherization programs as an extension of meeting their RCS requirements. That is, they provide not only audits but also energy-efficiency improvements. Frequentiy, the utility's public image is also enhanced as a result of providing services beyond simple energy audits. A growing justification for utility-sponsored weatherization efforts is the need to forestall the utility's need for increasing on-line generating capacity and the need to reduce peak demand.

\section{Financial Support}

Low-income weatherization programs presented in the matrix have received financial support from various sources, including the following:

- federal and state governments - Frequently some portion of funding is provided by the state and/or federal government, usually in the form of WAP or LIHEAP funds.

- utilities - These frequently are good sources of steady support.

- foundations/private donations - A few programs identified in this resource guide receive support from foundations such as AMOCO. Several other programs rely heavily upon private donations.

- self-generated - Many spin-off businesses generate funding for their weatherization efforts although many are still in their payback period.

One feature of the non-WAP/LIHEAP programs is that these programs frequently receive monies from several sources. For example, programs such as Seniors Helping Seniors, People's Natural Gas, Energy and Aging, and Weatherize Boston receive monies from government as well as nongovernment sources and utilities. 
Diversifying the source of financial support reduces the risk of the program relying on one funding source. If one organization decides to reduce or to eliminate its support, the weatherization based on diversified support has a better chance of surviving. Some programs have found an alternative method for assuring continuous program support by establishing profit-making businesses. These spin-off organizations often provide both materials for the weatherization program as well as money to support the effort.

Nonfinancial Support

Nonfinancial (in-kind) support of weatherization programs can take the form of any of the following:

- donated volunteer hours - Volunteers can perform a variety of tasks, including identifying low-income residents and weatherizing homes.

- donated materials - Materials donated to weatherization programs can range from caulking compounds to rolls of insulation.

- subsidized workers - Some businesses or utilities will donate a staff person to assist local weatherization efforts.

- information/training sessions - Utilities will often provide free information on home energy conservation and weatherization.

This support is often provided by several types of organizations, such as utilities, businesses and nonprofit and service organizations.

A review of the matrix indicates that about $50 \%$ of the programs reviewed received either volunteer support or material contributions. Again, most of the programs receiving nonfinancial support received it from more than one agency or organization. For example, the Seniors Helping Seniors and the Seniors Weatherization Program received nonfinancial support from utilities, businesses, nonprofit groups, and seniors' organizations. This diversification lessens the impact of one agency reducing its program participation and, consequently, reducing the program's ability to provide weatherizing services. The donation of volunteers and materials has added benefits, including stretching limited monies for use in other weatherization activities such as marketing, adding credibility to the program, and enhancing the image of program contributors.

\section{Marketing}

Many of the programs use promotion to solicit in-kind support. Various options are available for informing the public of the goals and objectives of the program and to solicit the public's assistance. The types of media used and techniques that have been found to be useful were discussed in the previous chapter on fundraising. The matrix shows the methods used by each program identified in the survey.

In the various weatherization programs that were reviewed, word of mouth was the most frequently used method. It was also noted that the ane-on-one 
interactions were often the best approach when soliciting volunteer support. There is really no good substitute for the personal touch afforded by word of mouth. It tends to make people feel as though their assistance is really needed by the program and that they are making a positive contribution. Also, it is much more difficult to turn down a person's plea for assistance in a one-on-one situation.

Often the promotional activities are designed and written by program staff and are published and distributed regularly. Self-produced newsletters are being used by several programs because they are an effective and fairly inexpensive way to keep the public informed of program progress. They are also a way of acknowledging the in-kind support of various organizations and individuals.

\section{What Factors Are Related to Successful Retrofitting Efforts?}

The residential retrofit programs listed in the matrix were also reviewed to identify any factors in addition to those listed above that may have led to a program's success (as we have defined it). The review of the survey identified the following success factors:

- dynamic director - Several of the programs identified noted that having a highly motivated and active director was a key element to their success. This individual acts as the program's chief sales person and cheerleader but may also be particularly effective in structuring the program in a workable way. Such a director can be instrumental in developing and maintaining critical relationships with supporters and in promoting interorganizational networks that reduce duplication of effort and competition for scarce resources.

Programs lacking this particular type of leadership may have to rely more heavily on fairly consistent sources of weatherization financial support, such as utilities.

- ability to network - The ability to draw on a variety of community resources was noted as a key to the success of several weatherization efforts. Many community organizations would be interested in providing support to low-income residential retrofit efforts if they were aware of program needs.

The key to successfully networking with various organizations is to first identify the weatherization program's principal needs. Are materials required? What about volunteers to perform the weatherizing? Next, it is critical to identify the various organizations within the area to be weatherized as well as the organization's capabilities. Can they provide volunteers? Do they have the ability to donate money and/or materials? 
The third key to successful networking is that the various organizations need to be informed of the program's efforts to provide low-income residential retrofit assistance. This can be done by sending a letter to each of the various community organizations, although most program directors noted that word of mouth was the most effective means of recruiting these individuals.

Once the various community organizations are recruited, it becomes essential that the program director or some other individual with strong leadership be involved to coordinate the activities of all parties involved. This coordination activity ensures that all program needs are being met and that services are not being duplicated.

- senior citizen/volunteer participation - The use of volunteer support by a low-income weatherization effort is an obvious way of extending a program's financial resources. The survey of low-income programs identified the use of senior citizen volunteers as key to several programs. Many senior citizens have both the time and a willingness to participate in weatherizing homes. The use of senior citizen volunteers has reduced problems such as poor quality work and inconsistent volunteer support, which were mentioned more frequently by programs using other kinds of volunteer support.

A key to successfully using senior citizens as volunteers is to minimize their costs to participate since most are living on limited income. For example, seniors who volunteer should be enrolled in Retired Seniors Volunteer Program (RSVP) since this program will compensate them for their gas mileage while they are engaged in retrofit activities.

A second key to successfully recruiting and using senior volunteers is making sure that their contributions are recognized and appreciated. Some programs hold annual banquets where senior volunteers are awarded certificates for their participation.

- agency support - The agency sponsoring the residential retrofit activity, such as a utility or private organization, must be fully committed to the program's activities. Furthermore, the agency must convey this support by addressing the needs of program staff immediately and champion the activity to the community. Such support can be conveyed using several media techniques such as brochures or speeches that endorse program activities. Round table discussions with residential retrofit staff will help identify program problems and needs, and are an effective means of reinforcing the support of the agency in the mind of the staff.

Such support is crucial when a retrofit program is recruiting financial as well as nonfinancial support from other organizations and individuals. Organizations and individuals are more likely to contribute funds, volunteer hours and materials if they feel that the program is receiving the backing of a major organization such as a utility or foundation. Such backing adds legitimacy to the effort. 
- incentives for partners and participants - A successful residential retrofit program requires the cooperative effort of various organizations and individuals. To recruit the assistance of these groups, a program must use incentives to make the groups' participation meaningful. An incentive frequently used to recruit businesses and service organizations is noting their association with the retrofit effort and making this association known to other businesses and community groups. One way of making this association is noting their participation in posters that businesses can display in store windows.

With individuals, an effective key incentive is the assurance that they are truly helping other, less fortunate individuals within the community. A second incentive is a feeling that through their donations they are indirectly helping to conserve energy.

- innovative product and good business management - Several of the spinoff businesses have provided a way to supplement program monies through the sale of innovative products. Blue Mountain succeeded because it manufactured a product that was needed by the residential retrofit effort and because the product is of high quality and is useful to others in the community.

Development of a successful spin-off business also requires a skillful business manager. If the business was a success before it was acquired by the residential retrofit program, try to retain key employees-particularly the manager. If the business was not successful or if it is a new business venture, try to recruit a manager with the skills to make the business a profitable operation.

Several generalizations can be made as to factors and attributes that are found in effective weatherization efforts that have been self-sustaining. These characteristics were found in several of the programs listed in the matrix and these factors have had a significant influence on the success of the programs. Such factors include:

- a specific targeted group - Focus on the weatherization needs of a specific group of residents rather than on all the residents within an area.

- diversification of financial and nonfinancial sources of support Diversifying funding sources will reduce the likelihood that the overall effort will fail. The programs that rely exclusively on one source for support are taking the risk that the weatherization effort will be significantly reduced if the funding source withdraws from the program.

- development of a profit-making venture out of weatherization - One way to develop an assured source of weatherization funds is to set up a successful spin-off business. A spin-off business can also help to ensure that the proper materials are available for weatherizing homes. In such a venture, a good manager to run the business is essential.

- promotion of the weatherization effort - Promotion of the weatherization effort should use the media most appropriate for the audience. A program 
newsletter is a recently developed method for increasing the visibility of a program. Once a program's name has been established, various media can be used. Word of mouth is still viewed as one of the best techniques for gaining program in-kind support.

- highly motivated director - Programs need an enthusiastic and dedicated director to promote the program. This must be a person who is convinced of the program's assets and is willing and able to sell the program to others.

Summary

This section has listed and discussed several characteristics that appear to be important in a sustainable residential retrofit program. However, including such elements as a strongly motivated director will not guarantee the success of a given effort. Program success and characteristics that have led to that success depend upon the specific situational factors. For example, strong and dynamic leadership may be an effective catalyst in a community where there is interest in assisting the needy, but a driving force to encourage businesses and volunteers to participate is needed. If that interest in helping the less fortunate is not already present within the community, a motivated director may not be able to provide sufficient impetus for a program to succeed.

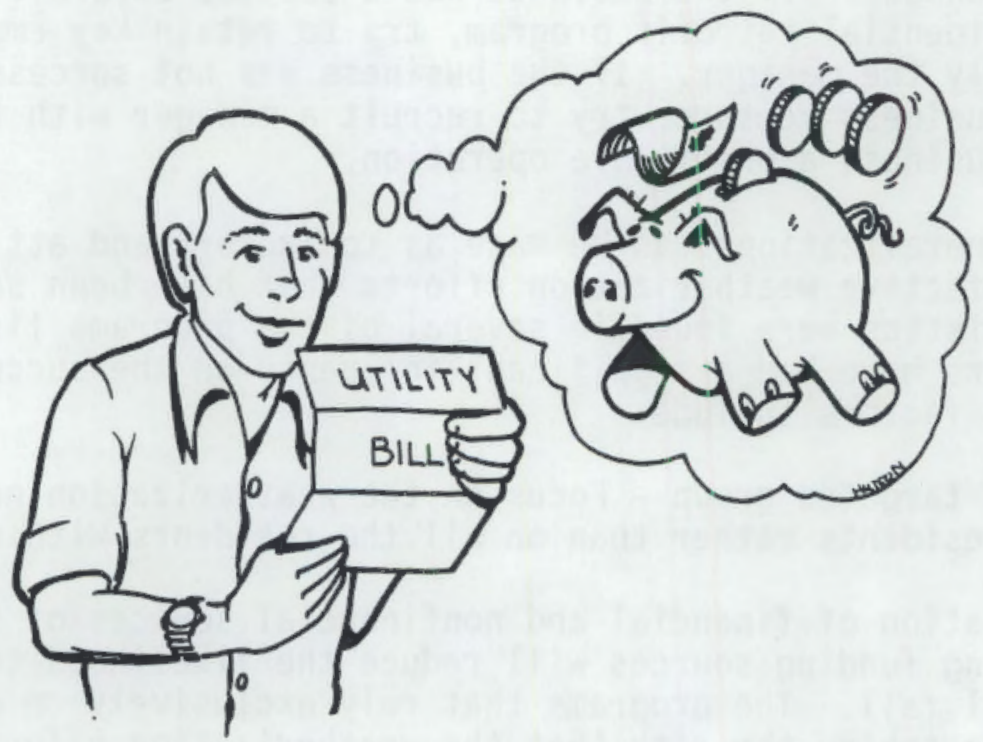

\section{CASE STUDIES}

The success of any residential retrofit effort is the result of several factors. The following five case studies were selected from the 50 residential retrofit programs identified in this report. These particular programs were selected to be described in more detail because they appear to be sustainable programs that have a diversity of financial and nonfinancial support, motivation, promotional techniques and success factors: 
- Project 2000 uses an innovative approach to solicit support from private businesses.

- Blue Mountain Economic Development Council illustrates how weatherization efforts can be turned into for-profit ventures.

- Senior Energy Savers shows how a nonprofit energy services corporation was formed through a partnership arrangement among the state offices, the public utility commission, utilities and nonprofit organizations.

- Centralia Area Energy Assistance Program illustrates how a utility formed a nonprofit foundation that solicits service group support to perform low-income weatherization.

- Capacity Building for Energy Conservation is an example of how six nonprofit organizations formed a consortium with the assistance of the AMOCO foundation.

These descriptions will illustrate how the various characteristics work together to build a sustainable program.

Project 2000

Nashville Electric Service

1214 Church Street

Nashville, Tennessee 37246

Contact: Jim Perkins

(615) 747-3665

\section{Background}

Project 2000 was started in 1980 by Nashville Electric Service (NES) to improve the energy efficiency of the homes of its low-income, handicapped, and senior citizen customers who were unable to pay their monthly electric bills. Project 2000 targets those customers who are above the income eligibility requirements for the state's low-income weatherization program, but who still need assistance.

When Project 2000 first began, the NES sponsored energy conservation training sessions for volunteers provided by college and church organizations. Once trained, these volunteers weatherized the homes identified in the NES service area. Materials for the original program were supplied through donations from private individuals; the energy conservation materials are now purchased with project funds.

Unfortunately, several problems arose with the original program, such as volunteers not showing up to perform the services and poor quality workmanship. To help resolve these problems, NES decided to train and pay high school students to weatherize homes. In 1983, NES hired 39 public and 5 private high school seniors to weatherize homes during an 11-week summer session. The students were chosen from several different social classes in order to promote interaction among the students. 


\section{Program Structure}

Project 2000 is directed and supervised by NES, with Jim Perkins as the project director. NES is responsible for hiring and training high school seniors to perform the energy conservation services, for conducting home energy audits, and for developing promotional efforts (see organizational chart).

The primary residents receiving the current Project 2000 energy conservation efforts are the elderly, handicapped and senior citizens. A senior citizen group is responsible for identifying the project recipients. The weatherization services performed are limited to those that reduce air infiltration, primarily weatherstripping. Weatherizing needs are identified through an energy audit performed by NES staff. If more than weatherstripping is needed, the resident is referred to the state energy office for further assistance.

\section{Program Support}

Private businesses within the community provide most of the project's financial support. In 1985 Project 2000 had a budget of $\$ 72,000$. The NES and the Tennessee Valley Authority (TVA) provide the staff salaries, and in 1985 , over $\$ 30,000$ was received from private sources. The private donations are used to pay the students' salaries and to purchase the materials. During 1985, 501 homes were improved in the 11-week summer session.

\section{Promotional Techniques}

NES relies on funds from private businesses for continuing operation. Fundraising within NES is the responsibility of its advisory board, which is made up of community leaders, as well as business and media people. Project promotional efforts begin with an annual kick-off breakfast to inform local businesses of the project's objectives and past weatherization accomplishments. After a brief presentation, pledgecards are passed out, and each business is asked to donate $\$ 2000$ to the project or whatever it can afford.

Businesses participating in the project are acknowledged through a program flyer that is sent to NES customers, at an annual awards banquet and through a certificate noting their support. High school seniors participating in the program also receive certificates.

\section{Program Accomplishments}

Project 2000 has proven to be a sustainable weatherization alternative and is viewed as a success by both the NES and the local Nashville community. Since 1984 over 1000 homes have been weatherized, about 100 high school seniors have been trained in weatherization techniques, and hundreds of individuals from various social classes have been able to interact.

Project staff have successfully solicited much of the funding for this project from private donations. The information breakfast is a novel approach that has been used quite successfully for encouraging private business support. 


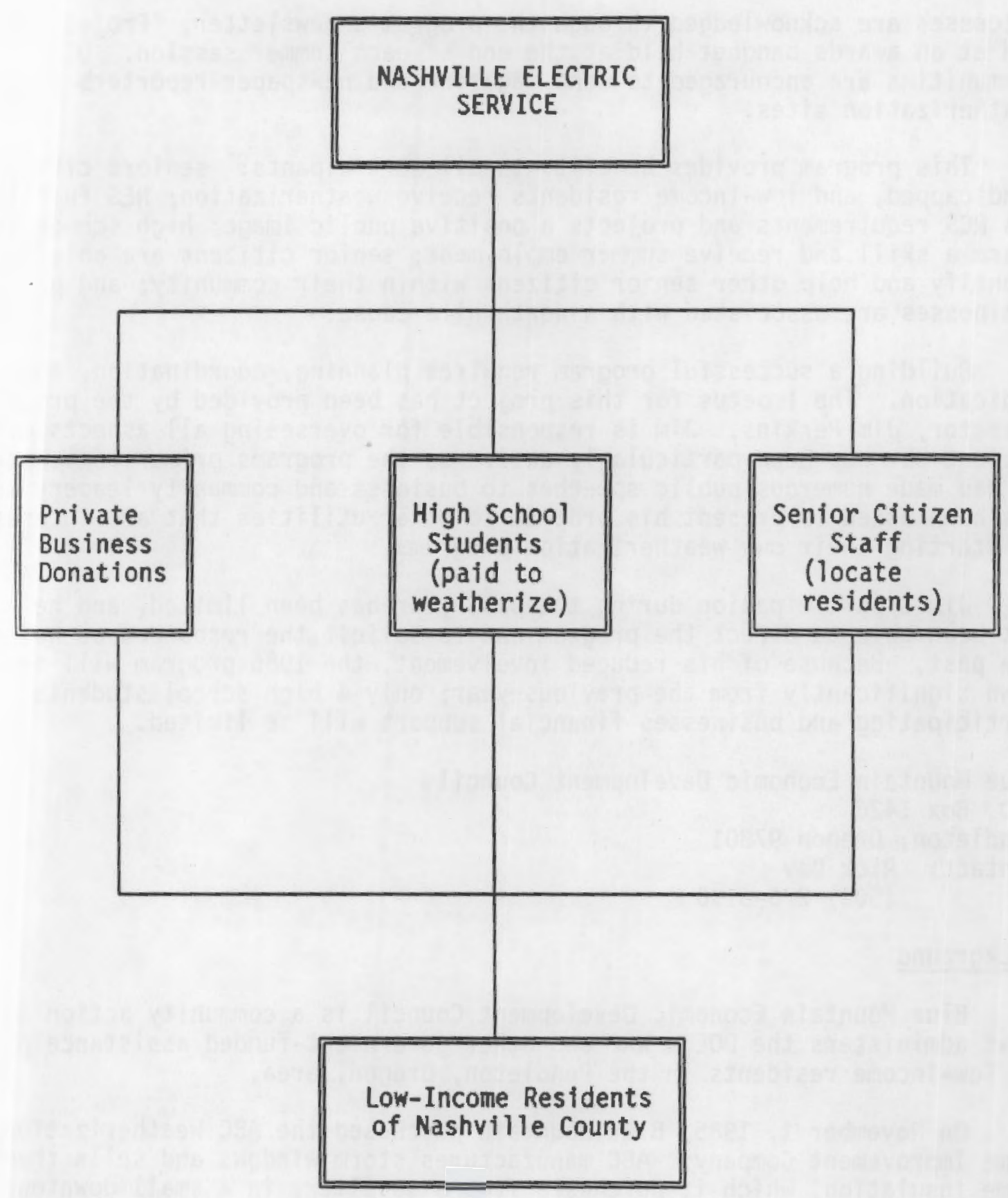


Successes are acknowledged through the program's newsletter, "Project 2000", and at an awards banquet held at the end of each summer session. Other communities are encouraged to send magazine and newspaper reporters to weatherization sites.

This program provides benefits to all participants: seniors citizens, handicapped, and low-income residents receive weatherization; NES fulfills its RCS requirements and projects a positive public image; high school seniors learn a skill and receive summer employment; senior citizens are able to identify and help other senior citizens within their community; and private businesses are associated with a worthwhile cause.

Building a successful program requires planning, coordination, and dedication. The impetus for this project has been provided by the project. director, Jim Perkins. Jim is responsible for overseeing all aspects of the project but has been particularly active as the programs primary salesperson. He has made numerous public speeches to business and community leaders and has been asked to present his program to other utilities that are interested in starting their own weatherization programs.

Jim's participation during the past year has been limited, and he has not been able to direct the program and to solicit the resources as he had in the past. Because of his reduced involvement, the 1986 program will be scaleddown significantly from the previous year; only 4 high school students will be participating and businesses financial support will be limited.

Blue Mountain Economic Development Council

P.0. Box 1426

Pendleton, Oregon 97801

Contact: Rick Gay

(503) $276-6136$

\section{Background}

Blue Mountain Economic Development Council is a community action agency that administers the DOE's WAP and other government-funded assistance programs to low-income residents in the Pendleton, Oregon, area.

On November 1, 1985, Blue Mountain purchased the $A B C$ Weatherization and Home Improvement Company. ABC manufactures storm windows and sells them and home insulation, which it purchases from a supplier, in a small downtown Pendleton shop. Before being purchased by Blue Mountain, ABC was the closest materials supplier of the type of storm windows that Blue Mountain needed. To use the nearest alternative materials supplier, Blue Mountain would have had to pay shipping costs. When $A B C$ 's former owner informed Blue Mountain that $A B C$ was for sale, Blue Mountain decided to purchase the business. Blue Mountain had an accountant and a banker on its board of directors who helped with the decision process and the actual purchase of the company. The decision to purchase $A B C$ was based on several factors: 
- $A B C$ was affordable and profitable.

- $A B C$ 's products could be used in Blue Mountain's DOE weatherization program to reduce its supplies costs and therefore stretch federal funds.

- $A B C$ was a small enough operation for Blue Mountain to handle.

- The person who had helped manage and run the business for the previous owner agreed to stay with the company after the sale.

- By purchasing ABC, Blue Mountain would have greater control over its material supplies.

\section{Program Structure}

Blue Mountain and $A B C$ are operated as separate ventures with different names, board meetings, employees, and offices (see organizational chart). Currently, $A B C$ employs three production workers, who manufacture a total of 30 to 40 storm windows per week. Workers at $A B C$ are paid hourly with no benefits, while Blue Mountain employees are on salary with health benefits.

\section{Promotion}

The storm windows produced by $A B C$ are sold to the public, mainly middleincome homeowners, in a downtown shop in Pendleton. Customers normally hear about the windows through word of mouth or through advertisements placed in the Yellow Pages. $A B C$ has not yet undertaken any sort of a promotional campaign to increase sales, largely because the business was only recently purchased and is just beginning to operate.

\section{Program Support}

Blue Mountain purchased $A B C$ for about $\$ 12,500$ plus inventory. The acquisition was financed through 1) a bank loan, 2) agency discretionary cash, and 3) a loan carried by the former owner. Because Blue Mountain uses the storm windows in its low-income assistance programs, it has saved money by getting the windows for cost. Profits from $A B C$ initially will be used to pay off loans and later will be used to supplement Blue Mountain's assistance programs, as needed. The loan from the former owner is expected to be paid off in 3 years or less.

\section{Program Accomplishments}

The Blue Mountain program has been successful in terms of meeting the objective of providing low-income weatherization by purchasing a for-profit business. By acquiring the company, Blue Mountain has a fairly consistent source of funding, has reduced the cost of its weatherization materials, and has ensured a consistent source of reliable materials. With the assurance of continued future financial support, Blue Mountain can establish a long-term plan for expanding its weatherization efforts to the needy in the Pendleton area. 


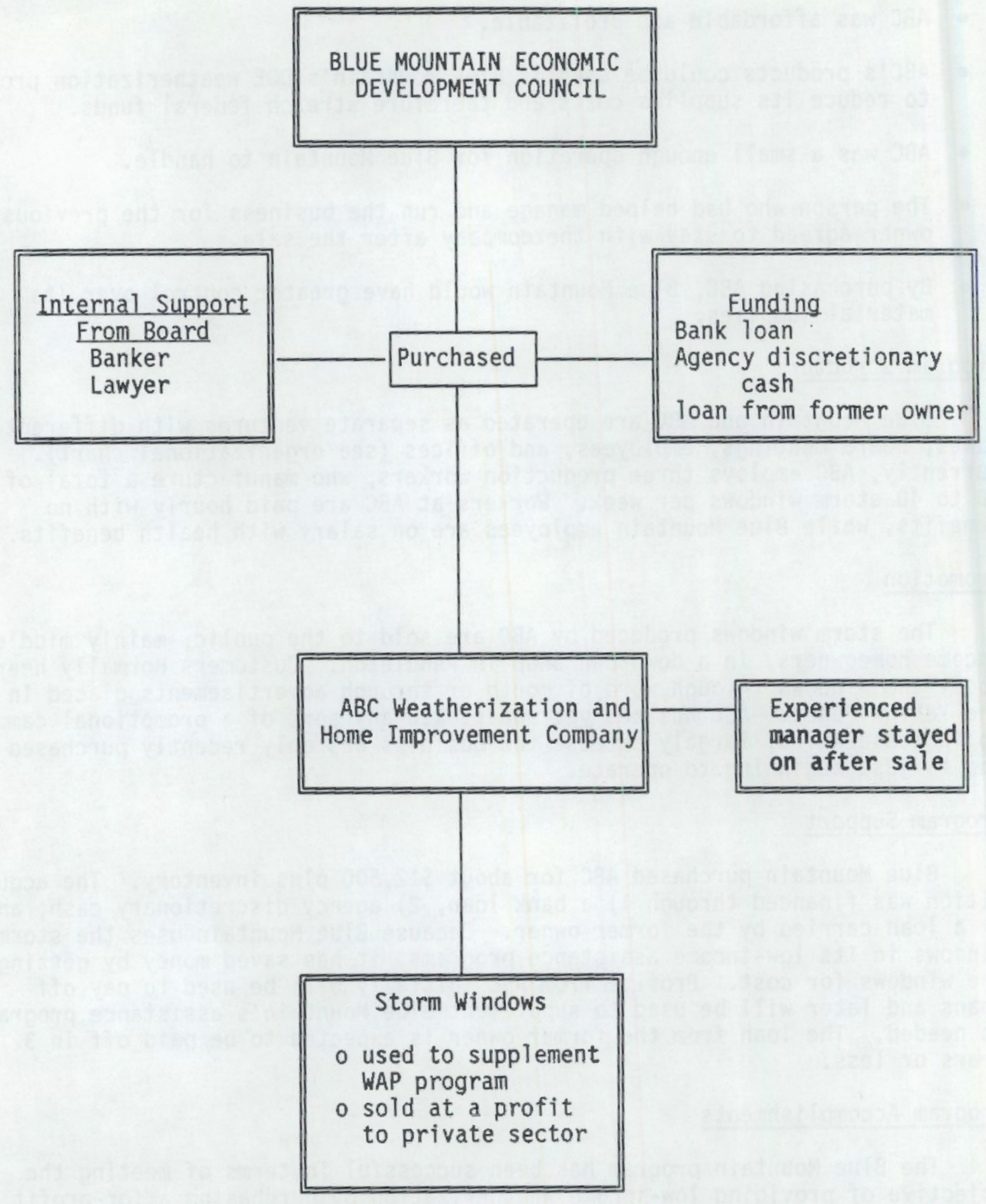


The continued growth in the $A B C$ weatherization business can be attributed to Blue Mountain's decision to retain the company's business manager. This move by Blue Mountain helped to ensure that the business was run properly and helped to retain the same clientele. A second factor that has lead to the success of this spin-off is that Blue Mountain has an accountant and a banker on its board of directors. These individuals, along with the business manager, have been instrumental in ensuring that the business is run profitably.

Discussions with various program directors who have decided to try spinoff businesses indicate that this particular move should be made with caution and only if sufficient business expertise is available to oversee the business.

Senior Energy Savers

North Carolina Alternative Energy Corporation

P.0. Box 12699

Research Triangle Park, North Carolina 27709

Contact: Keith Aldridge

(919) 549-9046

In 1980, the North Carolina Alternative Energy Corporation (AEC) was formed by the State Utilities Commission and six of the state's major utility companies: Carolina Power and Light Company, Duke Power Company, Electricities of North Carolina, Nantahala Power and Light Company, North Carolina Electric Membership Corporation, and North Carolina Power. The goal of this nonprofit corporation is to stimulate the efficient use of energy to reduce the need for new power plants and to keep consumers' electricity costs at an affordable rate.

AEC conducts several types of programs, including community programs that provide weatherization and education services. The goals of the AEC's community programs are 1) to help decision makers, particularly homeowners, renters, nonprofit organizations, schools and government, to realize the value of alternative energy systems for significantly reducing demand, and 2) to increase the use of energy-efficient systems by residential consumers. In most cases, the AEC works with other community groups and provides technical assistance and in some cases, provides initial financing for the program. Senior Energy Savers is an AEC comunity program that has been particularly successful. Its success, in turn, has led to the development of a statewide Energy and Aging Consortium. Each is discussed separately below (see organizational chart).

\section{SENIOR ENERGY SAVERS}

Background

In 1982, the AEC became interested in exploring innovative methods for providing energy education and services to senior citizens, who were not responding to AEC's programs through more traditional approaches. The Senior Energy Savers project was designed to demonstrate the feasibility of providing 


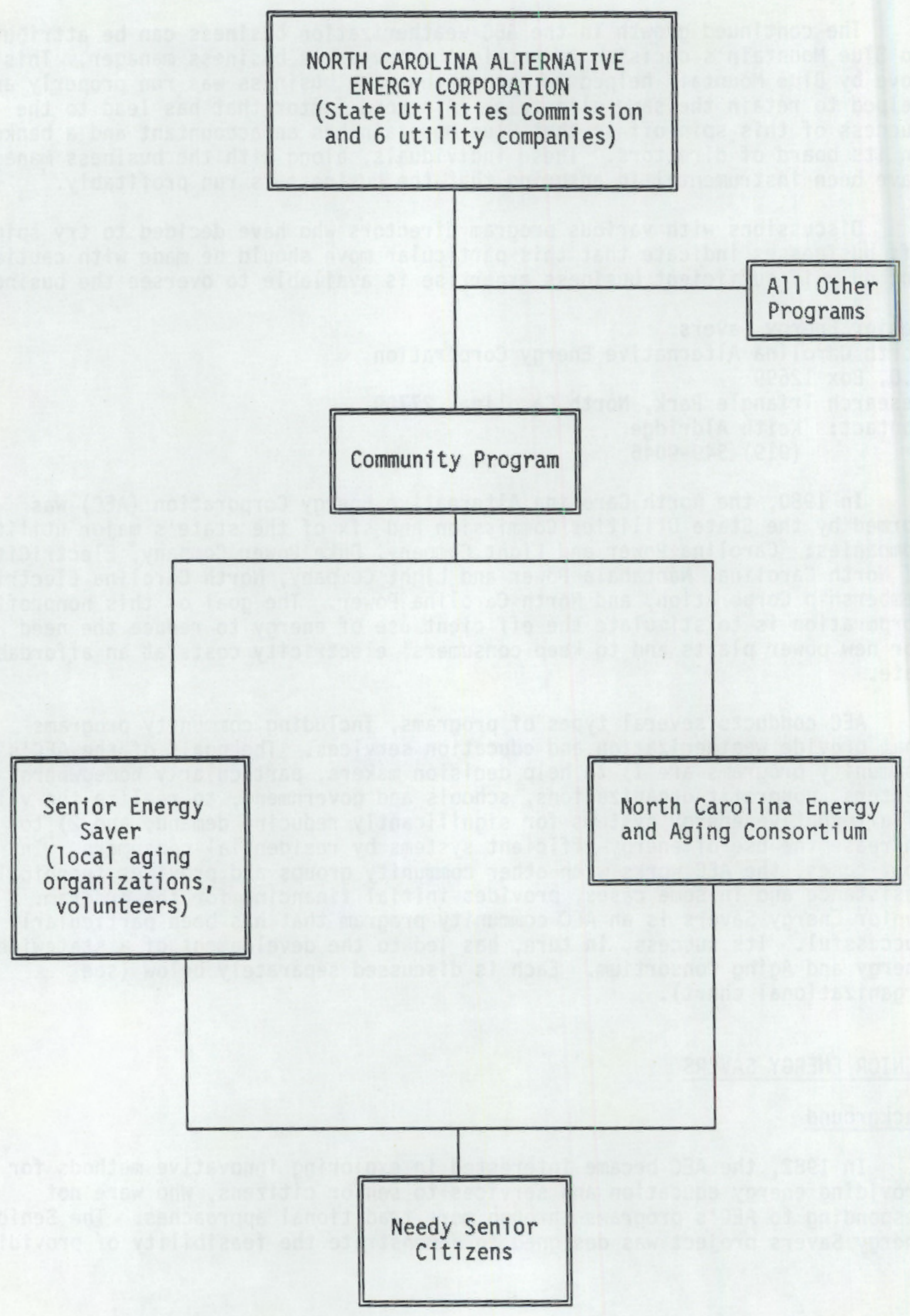

7.18 
such services. These efforts are designed to supplement other governmentfunded efforts; residents who are eligible for other programs are also referred to the appropriate state office.

\section{Program Structure}

To demonstrate the feasibility of the Senior Energy Savers' project, local nonprofit seniors organizations in seven counties were selected to sponsor Senior Energy Savers projects. The AEC provided technical and financial assistance to these seven organizations. These sponsoring agencies, which included churches, the YMCAs, and senior centers, recruited and trained volunteers to conduct simple home energy audits and to install low-cost energy conservation materials such as caulking, weatherstripping, door sweeps, storm windows, water heater jackets, and outlet covers. The volunteers were also given some tips on effective conmunication techniques to use with the elderly and were trained to inform these residents about further ways to conserve energy.

Since the Senior Energy Savers' program began, 1310 homes have received energy-efficient improvements by 673 volunteers, who have spent 8411 hours to help elderly citizens in their community. The program has spent an average of $\$ 70$ per home for services and the state has spent an average of $\$ 1000$ per home.

\section{Program Support}

The AEC provides technical assistance and seed money to groups for administrative and start-up expenses for their own senior citizen weatherization/education programs. Information provided to groups sponsoring these programs include specifics on the Senior Energy Savers' model program and strategies for fundraising and coordinating and managing volunteers. AEC has developed valuable resources in a "how-to" manual to assist organizations in all areas of implementing a program and in recruiting and using volunteers.

Local social service agencies help these groups identify potential elderly residents for assistance. In addition to their contributions to the AEC, utilities will often provide energy conservation materials to the groups.

\section{Promotional Techniques}

A step-by-step manual and slide show was developed to assist community groups in organizing local volunteer campaigns for Senior Energy Savers' projects. Staff in the Senior Energy Savers program suggest that one way to successfully recruit volunteers is to pay a "key" motivated and enthusiastic person to take charge and oversee the recruiting activities.

\section{ENERGY AND AGING CONSORTIUM}

\section{Background}

The success of the Senior Energy Savers' projects in providing weatherization/educational assistance to elderly residents led to the formation 
and organization of Energy and Aging Consortium. The Senior Energy Savers' program is still providing technical assistance to local groups interested in designing energy conservation programs for senior citizens, but it is also organizing the consortium. The purpose of the consortium is to encourage cooperative efforts in energy conservation and education among the utilities and their elderly customers, statewide organizations, and local community groups.

\section{Program Support}

The AEC receives nearly all of its funding from the member utility companies, whose donations have steadily increased since 1983. In 1985, about $\$ 2.7$ million was donated and dispersed among AEC's programs. The amount of funds spent on the Senior Energy Savers project from October through November 1985 to provide technical assistance to organizations and to form the Energy and Aging Consortium was $\$ 39,048$.

The AEC provided technical assistance to the consortium through a guide, SENIOR ENERGY SAVERS - A HOW-TO Guide for Organizing Local Weatherization Projects. The guide was designed mainly to help the organizations implement their weatherization programs. However, the guide also may encourage groups to undertake a weatherization project because it provides information about all aspects of undertaking and managing the program. The guide also includes specific promotional information such as ideas for recruiting through the media, recruiting special groups (skills), and various ideas for workshops/energy campaigns.

\section{Promotional Techniques}

AEC initially held a brainstorming session with state officials and nonprofit groups involved with the elderly, such as the Council on Aging and the area Agency on Aging, in order to identify organizations that might be interested in becoming involved with the consortium. Organizations identified were then contacted, briefed on the consortium and asked to attend an informational meeting. The informational meeting was intended to gain the support and involvement of these groups.

Currently, about 20 organizations are actively involved in developing the consortium. These groups are encouraged to take an active part in determining the goals, objectives and organization of the consortium. This may encourage the groups to become more involved if they have an active part in forming the consortium and can claim some "ownership."

A survey to assess the energy needs of elderly citizens was developed and distributed to senior centers across the state. A brochure explaining the purpose and goals of the consortium has also been developed, by the American Association of Retired Persons.

Program Accomplishments

The State of North Carolina has extended the North Carolina Alternative Energy Corporation's lifespan from 1985 to 1990. The success of this program 
can be attributed to the ability of the state utilities commission, the six utilities and the seven nonprofit organizations to work together.

The Senior Energy Savers' program was developed by the AEC to combat the lack of senior citizen involvement in AEC's more traditional weatherization programs. This program required the cooperative effort of several nonprofit organizations in seven counties. The Senior Energy Savers' program has demonstrated a viable model for weatherizing homes with the assistance of nonprofit organizations and individuals by focusing on the weatherization needs of the elderly. Through this program, 1310 homes have been weatherized by 673 volunteers representing various nonprofit groups. Significant assistance and encouragement were provided to the Senior Energy Savers' program, including technical information, seed money, and administrative assistance.

Similarly, the North Carolina Energy and Aging Consortium was established by the AEC as a mechanism for continued growth of energy conservation and education projects, once again focusing on the needs of the elderly. This consortium will facilitate cooperation and nontraditional interaction among organizations concerned with the needs of the elderly in a more "formal" and regular basis.

Centralia Area Energy Assistance Program

Ministerial Alliance

1606 East Second Street

Centralia, Illinois 62801

Contact: The Reverend Loren Rovenstine, Program Director (618) $532-7776$

\section{Background}

The Centralia Area Energy Assistance (CAEA) Program was organized in 1983 and began operation in May of 1985. This program is one of many in a large network of gras5-roots, community programs that are funded by the Energy Assistance Foundation. The Foundation, in turn, is primarily funded and administered by the Illinois Power Company.

The Foundation makes grants to the grass roots organizations, such as the Ministerial Alliance of Centralia, to administer energy conservation services at the local level where low-income individuals do not qualify under the traditional programs but need assistance. The CAEA Program was developed primarily to weatherize the homes of those area residents whose incomes were just above the limit set by the state/federal weatherization program (a family of 2 with less than $\$ 10,800$ income annually).

The Ministerial Alliance of Centralia is one of the several nonprofit community groups that the Energy Assistance Foundation funds to perform energy conservation services. Each group (organization) determines its own program by foundation guidelines. The programs are throughout Illinois Power Company's 11 service areas, which cover $25 \%$ of the state of Illinois. 


\section{Program Structure}

The nonprofit organization directing the energy-efficiency improvements decides what groups of people will receive first priority. The overall guidelines for prioritization are 1) senior citizens, 2) handicapped, and 3) singleparent families. If there is an exceptional case that is outside of these categories, the sponsoring group can choose to help them; the group is not bound to certain eligibility requirements. Also, if an unusual amount of help is needed by an individual, the Foundation's director must approve the case. Any group or individual can refer people for assistance, or anyone can apply for assistance. If a resident qualifies for another program, he/she is referred to the appropriate agency.

The Illinois Power Company performs a pre-audit of all homes to be weatherized. The services provided through the program consists of attic insulation, weatherstripping, caulking, window repair (panes and operations), storm window repair, water heater jackets, and occasionally a furnace replacement. Twelve homes were weatherized in the first eleven months of the program's operation. No house has exceeded $\$ 1200$ in services and the average has been $\$ 600$.

The alliance uses all volunteers to perform the energy conservation services: five of the fifteen churches in the alliance have provided volunteers. The program director tries to get volunteers from any church that has parishioners who apply for assistance in order to broaden the base of volunteers. However, the sponsoring group has the option to subcontract the weatherization work, or in a few cases the resident can be given the materials and make the improvements.

All installations are inspected. The executive director of the Foundation is responsible for follow-up audits and for providing the Alliance with a print-out of any application, energy-audit recommendations from initial audits, and follow-up audits when weatherization is completed. The Foundation supplies the computer processing of applications and tracks the program.

\section{Program Support}

The CAEA program is funded by the Energy Assistance Foundation and by customer contributions (through their bills) (see organizational chart). The CAEA is a continuing program which draws from a foundation fund that was originally started with $\$ 250,000$ granted from the Illinois Power Company and an additional $\$ 60,000$ contributed from utility customers in a bill check-off system (any amount from $\$ 1.00$ ). Customer contributions have varied from $\$ 50,000$ the first year, to $\$ 16,000$ the second year, to about $\$ 27,000$ as of May 1986 . The Illinois Power Company matches customer contributions.

\section{Promotional Techniques}

To promote customer contributions, the Illinois Power Company allows one insert per year in their customers' bills to inform the customers about the program and to receive their commitments. Any additional local contribution of time, talent or money is the result of the one-on-one and direct appeal 


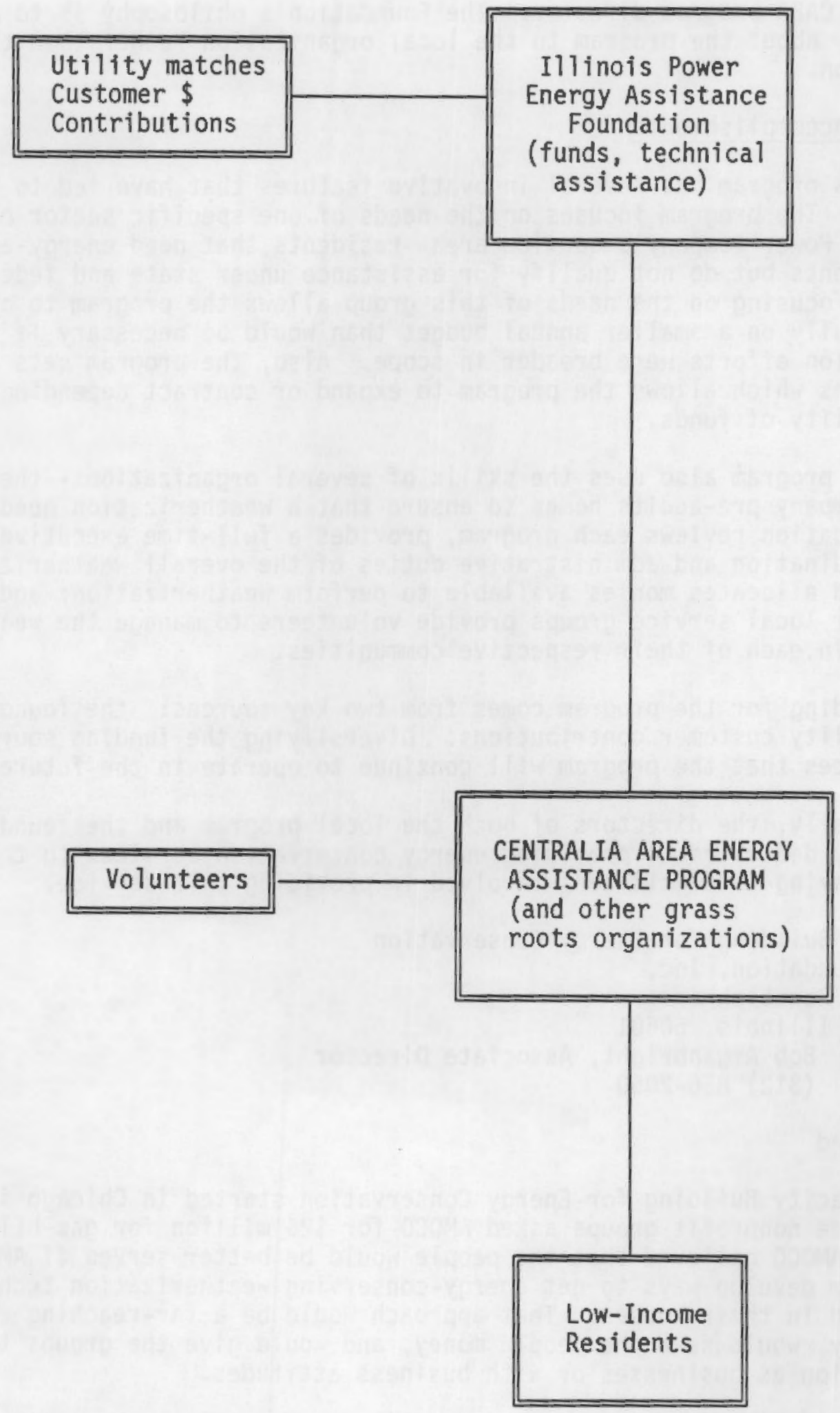


from the CAEA program director. The Foundation's philosophy is to direct any publicity about the program to the local organization rather than to the Foundation.

Program Accomplishments

This program has several innovative features that have led to its continued success. The program focuses on the needs of one specific sector of the Illinois Power Company's service area--residents that need energy-efficiency improvements but do not qualify for assistance under state and federal guidelines. Focusing on the needs of this group allows the program to operate successfully on a smaller annual budget than would be necessary if their weatherization efforts were broader in scope. Also, the program sets assistance priorities which allows the program to expand or contract depending on the availability of funds.

The program also uses the skills of several organizations--the Illinois Power Company pre-audits homes to ensure that a weatherization need exists; the Foundation reviews each program, provides a full-time executive director for coordination and administrative duties of the overall weatherization program, and allocates monies available to perform weatherization; and churches and other local service groups provide volunteers to manage the weatherization program in each of their respective comnunities.

Funding for the program comes from two key sources: the foundation and from utility customer contributions. Diversifying the funding source enhances the chances that the program will continue to operate in the future.

Finally, the directors of both the local program and the foundation are sincerely dedicated to providing energy conservation services to the needy and to having local citizens involved in providing this service.

Capacity Building for Energy Conservation

AMOCO Foundation, Inc.

200 East Randolph

Chicago, Illinois 60601

Contact: Bob Arganbright, Associate Director

(312) $856-2050$

\section{Background}

Capacity Building for Energy Conservation started in Chicago in 1982 when three nonprofit groups asked AMOCO for $\$ 26$ million for gas-bill assistance funds. AMOCO believed that the people would be better served if AMOCO could help them develop ways to get energy-conserving weatherization technology installed in their houses. That approach would be a far-reaching conservation of energy, would save the people money, and would give the groups the capability to function as businesses or with business attitudes.

With three other community nonprofit groups that AMOCO had previous experiences with, the three original nonprofit groups formed a group of six "grass roots" nonprofit organizations that became involved in the program: 
Bethel New Life, Neighborhood Institute, North River Commission, Northeast Community Organization, Northwest Community Organization, and South Austin Action Coalition Community (SAACC) (see organizational chart).

\section{Program Structure}

Because these neighborhood organizations were in the low-income areas of the city, the consortium served a low-income weatherization need, although it also helped some moderate-income residents in these communities.

AMOCO's program with the six nonprofit organizations was structured in three phases:

1. Each group was given $\$ 2,500$ to develop a business plan for their own neighborhood weatherization work. The plan had to be reviewed and approved by AMOCO before the group could begin the next phase. If the plan needed to be clarified, AMOCO provided assistance.

2. Each group received $\$ 15,000$ to implement their business plan in order to prepare for full-scale operation. The groups could use this money for hiring subcontractors for installing weatherization services, recruiting and setting up a plan for training volunteers, and getting bids or contracts for materials for the program.

3. When a viable business plan had been approved, the group received $\$ 50,000$ for its first year of operation.

These groups progressed at different rates because they had different levels of expertise. Each group was given the freedom to develop a program that was judged suitable for its particular neighborhood. There was no one format.

A seventh nonprofit organization, the Center for Neighborhood Technology, was involved in the program by providing consulting and technical assistance. Scott Bernstein, an engineer at the Center, provided that assistance.

All six of the organizations met the requirements and went into operation in their first year. Two received their grants before the end of 1982, and the others completed their planning and preparations in 1983 . Over $\$ 400,000$ went into the program with the completion of the 3 phases. This did not include the cost to the Foundation of Bob Arganbright's administration and leadership.

Program Accomplishments

The key elements in the success of this program were the groups' ability to successfully develop and implement their business plans and their systematic approach to the program development. Before the first year of operation was completed, the six groups were able to function in a consortium, bid for and be awarded, approximately $\$ 15$ million that was available from the City of Chicago and utilities for low-income weatherization. They had the wisdom to form a partnership with two other nonprofit organizations that could provide the additional expertise that a project of that scope would involve. The two 


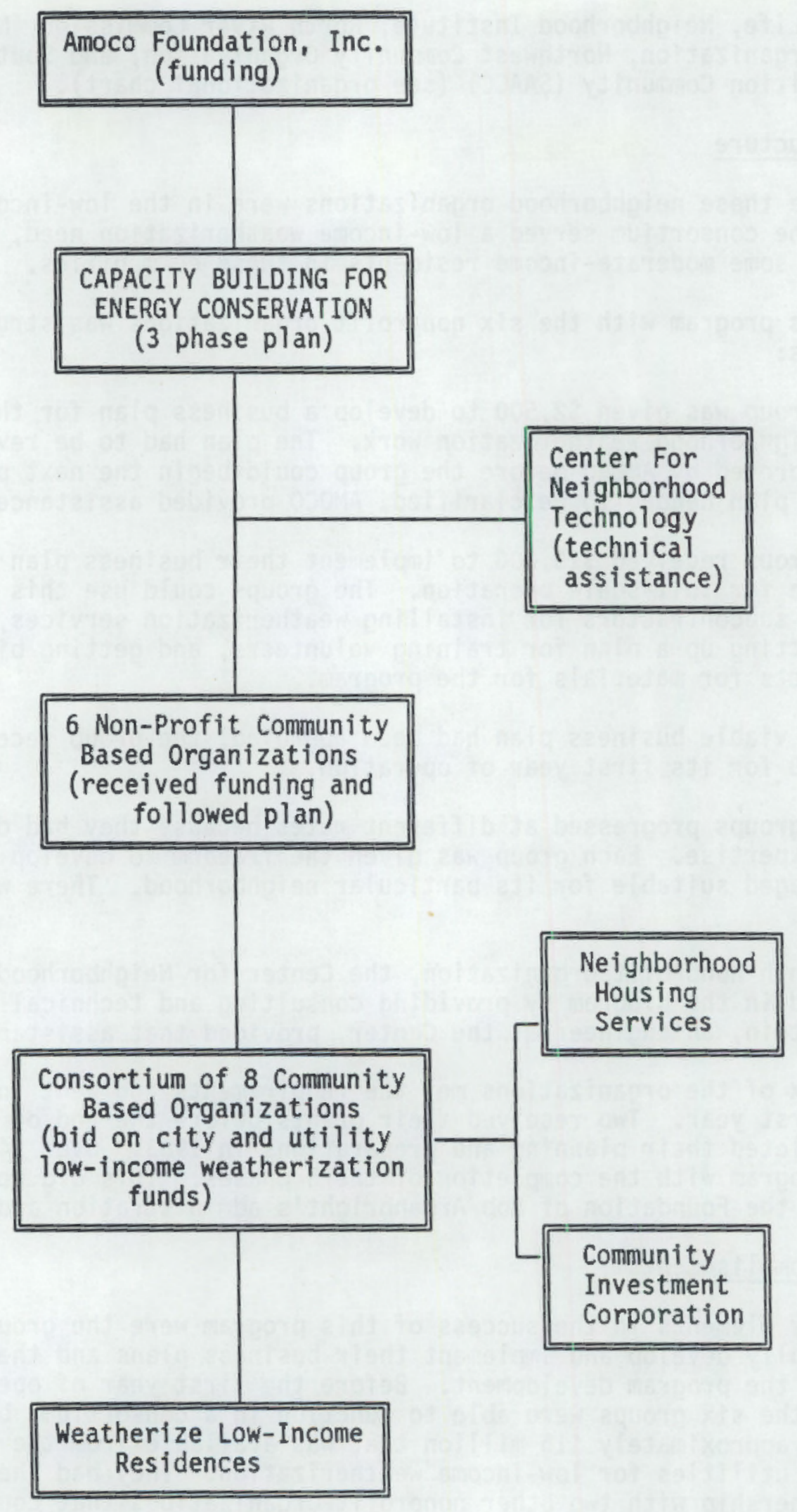


groups were Neighborhood Housing Services and Community Investment Corporation, which is itself a consortium of lending institutions in the Chicago area that serve low-income energy conservation and improvement programs. The consortium of eight groups competed in chicago for the bid to administer the funds and won it on their own merit with their organizational abilities, their business-like approach and their track record.

In addition, this program had several innovative features: 1) it was more than a stop-gap; 2) program participants learned how to help themselves; 3) neighborhoods could make plans which seemed appropriate to their own priorities; and 4) both organizations and individuals were given an opportunity to better understand and to better use energy conservation technologies to their advantage. 


\section{REFERENCES}

Bleviss, B., and A. Gravitz. 1984. Energy Conservation and Existing Rental Housing. Energy Conservation Coaltition, Washington, D.C.

Cassidy, R. 1980. Livable Cities: A Grass-Roots Guide to Rebuilding Urban America. Holt Reinhart and Winston, New York, New York.

Church/Davis Architects. 1984. Market Research: Energy Conservation Opportunities in New Commercial Buildings. Prepared for the Bonneville Power Administration, Portland, Oregon.

Crowe, J., and L. Callaway. 1985. "Pacific Gas and Electric Company's Conservation Porgrams for Multi-Unit Dwellings." Presented at a Conference "Energy Conservation in Rental Housing: What Works." Sponsored by the California Energy Commission, Sacramento, California.

Dermer, J., and S. Wertheimer. 1982. The Complete Guide to Corporate Fund Raising. Available from the Public Service Materials Center, Hartsdale, New York.

Director of Corporate Advertisers. Available from the Public Service Materials Center, Hartsdale, New York.

Dun \& Bradstreet Million Dollar Directory. Available from the Public Service Materials Center, Hartsdale, New York.

Dun \& Bradstreet Reference Book. Available from the Public Service Materials Center, Hartsdale, New York.

Fay, B. K. 1984. "Voluntary Rental Living Unit Program." In Proceedings of the 1984 Summer Study on Energy-Efficiency in Buildings. Sponsored by the American Council for an Energy-Efficient Economy, Washington, D.C.

Flanagan, J. 1977. The Grass Roots Fundraising Book: How to Raise Money in Your Community. Swallow Press, Chicago, Illinois. Available from The Youth Project, 1000 Wisconsin Ave., N.W., Washington, D.C. 20007.

Friedman, S. 8. 1982. "Multifamily Energy Conservation: Owners' Economic Perspectives." In Energy Efficiency in Buildings: A State Policy Handbook. National Conference of State Legislatures, Denver, Colorado.

Funkhouser, D., M. S. Jensen and I. Reiff. 1982. Investigation of Multifamily Issues. Prepared by Urban Systems Research \& Engineering, Inc., Cambridge, Massachusetts, for the U.S. Department of Energy, Washington, D. C.

Hall \& Associates, 1984. "Multifamily Survey Five Units and Above." Prepared for Seattle City Light, Seattle, Washington. 
Harbicht Research, Inc. 1984. "Weatherization Financing and Credits Program: An Exploratory Investigation of the Multifamily Market." Prepared for Southern California Gas Company, Arcadia, California.

Klein, D. J. 1975. Developing Human Services in New Communities. Behavorial Publications, New York, New York.

Kotler, P. 1982. Marketing for Non-Profit Organizations. Prentice-Hall, Inc., Englewood Cliffs, New Jersey.

Levine, A., et al. 1982. Energy Conservation in Rental Housing: Landlord's Perceptions of Problems and Solutions. SERI/RR-744-1308, Solar Research Institute, Golden, Colorado.

Liebert, E., and B. Sheldon. 1972. Handbook of Special Events for Non-Profit Organizations. Associated Press, New York, New York.

Markin, R. J. 1982. Market Strategy and Management, 2nd Edition. John Wiley \& Sons, New York, New York.

McColley, B. J. 1985. Brokering Energy Partnerships. Proceedings of the 1985 SECP/EES All-States Program Manager's Conference. Available from the Arizona Energy Office, Phoenix, Arizona.

Northwest Power Planning Council. 1986. Northwest Conservation and Electric Power Plan, Volume Two. Northwest Power Planning Council, Portland, Oregon.

Pendleton, N. 1981. Fund Raising: A Guide for Non-Profit Organizations. Prentice-Ha11, Inc., Englewood Cliffs, New Jersey.

Real Estate Research Corporation. 1985. "Real Estate Report." Volume 14, Real Estate Research Corporation, Chicago, Illinois.

Schroeder, C., and A. Miller. April 1982. "The Validity of Utility Conservation Programs According to Generally Accepted Regulatory Principles." Solar Law Reporter.

Sheridan, P. G. 1968. Fund Raising for the Small Organization. M. Evans \& Company, Inc., New York, New York.

Standard and Poor's Register of Corporations, Directors, and Executives. 3 Volumes. Annual. 25 Broadway, New York, New York.

Standard and Poor's Register--Geographical Index. Annual. 25 Broadway, New York, New York.

Stern, P.C., et al. 1985. "Residential Conservation Incentives." Energy Policy.

Strauss, B. and M. E. Stowe. 1974. How to Get Things Changed: A Handbook for Tackling Community Problems. Doubleday, New York, New York. 
Survey Research Center. 1984. "Attitudes, Opinions, and Concerns About Energy: A Survey of Oregon Residents." Survey Research Center, Oregon State University.

Synergic Resources Corporation. 1984. Conference on Ut 11tty Conservation Programs: Planning, Analysis, and Implementation, Prepared by Synergic Resources Corporation, Bala Cynwyd, Pennsylvania.

The Foundation Center. Foundation Grants Index Bimonthly. The Foundation Center, 888 Seventh Avenue, New York, New York 10106.

The Foundation Center. 1981. Source Book Profiles. The Foundation Center, 888 Seventh Avenue, New York, New York 10106.

The Foundation Center. 1981. The Foundation Directory, 9th ed. The Foundation Center, 888 Seventh Avenue, New York, New York 10106.

The Foundation Center. 1984. The National Data Book, 8th ed. The Foundation Center, 888 Seventh Avenue, New York, New York.

Thomas Register of American Manufacturers. Available from the Public Service Materials Center, Hartsdale, New York.

Trecher, H. B., and A. R. Trecher. 1979. Working With Groups Committees and Communities. Association Press, Follett Publishing Company, Chicago, ITlinois.

U.S. Office of Technology Assessment. 1982. Energy Efficiency of Buildings in Cities. PB82-200346, National Technical Information Service, Springfield, Virginia.

Western States Shelter Network. 1982. Dollars and Sense: A Community Fund Raising Manual for Women's Shelters and Other Non-Profit Organizations. Western States Shelter Network, San Francisco, California. 
APPENDIX A

NONFEDERAL PROGRAMS IOENTIFIED IN SURVEY 
APPENDIX A

\section{NONFEDERAL PROGRAMS IDENTIFIED IN SURVEY}

Appendix A contains descriptions of low-income residential retrofit programs sponsored by utility companies, community service organizations, nonprofit groups, and state or city governments. These programs were identified through contacts made with State Energy Offices and other sources. A contact person and organization are provided so that further information may be obtained on the program. 
Community Energy Management

Michigan Department of Commerce

P.0. Box 30228

Lansing, Michigan 48909

Contact: Barb Chubb

(517) 373-9090

The Community Energy Management (CEM) program is sponsored by the Michigan Department of Commerce to save energy and jobs in Michigan. The major component of this program is the Neighborhood Open Houses, which are held at several locations throughout the city, usually at community centers, schools, etc., at differing times.

The program uses volunteers to encourage residents to take energy conservation actions in their homes. As a demonstration tool, these volunteers are trained to interpret thermograms (heat loss pictures of homes) that are taken of an area before an open house is held. Residents are informed about where they are losing heat in their homes, what actions could reduce heat loss, why they should sign up for the residential conservation standards (RCS) audit offered by utility companies, and how they can finance energy conservation actions.

Neighborhood Open Houses are designed to reach $25 \%$ of the homeowners in the city. Since 1980, 2,100 volunteers each have received 6 hours of conservation training, and about 31,000 people have been taught about conservation through this program. The Michigan Department of Commerce provides local CEM coordinators with a wealth of information on how to promote these open houses and recruit volunteers. Although this is not a low-income program, the program model and technical assistance would be of value to any program using volunteer support. 
Operation Threshold

Community Assistance Program

120 Independence Avenue

Waterloo, Iowa 50703

Contact: Ray McIntire, W. P. Director

(319) $235-6243$ or $233-7886$

Operation Threshold is a traditional community action agency that is a subcontractor for the DOE's Weatherization Assistance Program (WAP) and LowIncome Home Energy Assistance Program (LIHEAP). The director of this agency, Mr. McIntire, has been able to obtain additional funds that have increased the number of homes weatherized. One such source is utility money. Another source is through other subcontractors who cannot fully use their funding; Mr. McIntire requests that the funds be transferred to his project. For example, Mr. McIntire obtained funding from the area Agency on Aging for 12 roofs for aging residents. From June to November 1985 , he administered $\$ 519,466$ (from all sources) in energy retrofit materials and labor.

To select residents to receive program assistance, Mr. McIntire has developed a point system that includes these criteria: elderly or handicapped; electric heat, oil or liquid petroleum gas in the home; single-family residence or family with small children (under age 3 ); and $125 \%$ of $150 \%$ low-income poverty guideline levels. By applying point values to each applicant for each criterion met, the requests are prioritized, which saves time in decision making.

In November 1985, Mr. McIntire expanded the agency's effort to include energyefficiency improvements to older mobile homes. For many years, mobile home designs did not include energy-conservation technology, al though measures are avallable to conserve energy in them and to contain energy costs. Today's manufactured housing usually includes energy-efficient components. 
Project HELPER

Lucas State Office Building

Des Moines, Iowa 50319

Contact: John Burnquist, Program Planner

(515) $281-3268$

Project HELPER--Helping Elderly and Low-Income Persons with Energy Relief-was originally a mandate of the governor of Iowa when he was inaugurated in 1983. The purpose of the project is to provide energy-efficiency improvements for residents outside the DOE's Weatherization Assistance Program (WAP) limits. The people targeted for assistance are those at or below the $150 \%$ of poverty (DOE guidelines), particularly the elderly and handicapped. Eligibility also may be established by a self-declaration of need.

Proceeds from the 1983 inaugural ceremonies were contributed as the seed money to start the project. Iowa businesses and industries contribute to the project, and Iowa utility companies participate in a check-off program that allows customers to add a voluntary contribution to their fuel-bill payments.

Under the project, 4,000 to 5,000 residences are expected to be improved at a cost of $\$ 16$ to $\$ 50$ per home. HELPER contracts with the 19 community action agencies throughout Iowa to purchase and distribute the low-cost retrofit materials to be used. The materials are 3 mil plastic, weatherstripping and caulk and cost about $\$ 16.50$ per household. Volunteer groups and community organizations distribute and install the materials for those who cannot do it themselves.

An ongoing statewide network of community service organizations and churches have established a list of local volunteers to assist with applications for low-cost materials. To the greatest extent possible, funds are used within the county where they were raised.

The key elements of the project's success are the governor's leadership, which enables the support of the State Energy Assistance Division and the Governor's office on Volunteerism, and the networking with the 19 community action groups statewide. Public support through contributions in utility bills has also been important. 
Limited Income Energy Assistance Program

Energy Extension Service

270 Washington Street S.W.

Atlanta, Georgia 30334

Contact: Elizabeth Sparrow Robertson

(404) 656-5176

The Limited Income Energy Assistance Program was developed by the Energy Extension Service (EES) in 1980 to provide conservation information to lowincome individuals and the elderly. This program was specifically developed to reach residents who are not being reached through the more traditional methods, such as mass media promotional campaigns.

The program is staffed by volunteers who are trained by the EES in conservationrelated subjects such as air infiltration, energy management, comfort factors, money management, and heat loss/heat gain. The volunteers deliver this information to the target audience individually in their homes or in small groups. Volunteers are usually members of groups or organizations that have established networks for working with the elderly and low-income individuals. Different packages of materials have been developed to match the differing levels of education and understanding of conservation among low-income groups.

This program has had a total funding of $\$ 200,000$ since 1980 and has reached about 35,000 residents. The program is expected to grow substantially in 1986 with the addition of $0 i$ l overcharge funds. 
Six Points Evaluation and Training, Inc.

Office of Energy Conservation

125 W. Virginia

P.0. Box 1002

Gunnison, Colorado 81230

Contact: Marilyn Leftwich

(303) $641-3081$

Six Points is a workshop/training facility for developmentally delayed adults. During the summer of 1985, the workshop started supplementing its state funding with the Weatherization Assistance Program contracts through the office of Energy Conservation. The residential retrofit work also provides a source of job training for the workshop participants, who install the energy-efficiency improvements.

Six Points has contracted to improve 75 homes in 1986 at a total program cost of about $\$ 25,500$. Services include weatherstripping, caulking, and installing door sweeps, hot water heater wraps, and plastic covers for windows. Six Points will also provide cost and effectiveness information to homeowners on additional energy conservation measures.

The maximum expenditure per home is $\$ 300$. Low-income homeowners are informed about the available services by word of mouth, announcements at religious and senior citizen meetings, and public service messages carried by local radio and television stations. 
Alabama Energy Systems for Low-Income Groups

Alabama A \& M University

P.0. Box 22

Alabama A \& M University

Norma 1, Al abama 35762

Contact: Chinella Henderson

(205) $859-7446$

The Alabama Energy Systems for Low-Income Customers (AES) was a pilot program sponsored by Alabama A \& M University with a $\$ 97,033$ grant from the Alabama Cooperative Extension Service. This program began in 1979 and operated for 18 months.

The program focused on 30 "model families" who were given training on low-cost energy conservation techniques. The families then served as outreach agents to other low-income families in their communities. These model families set up and taught energy conservation workshops to their neighbors. About 72 seminars and workshops were held during the term of the program, and over 2,500 low-income residents were reached.

Model families were identified through area social-service-type agencies that could help identify people who had established themselves as community leaders. The idea behind using model families was that these people would be more readily accepted by the target audience, which consisted largely of low-income black people residing in rural areas. 
Demonstration window

Elderly/Fixed Income Weatherization Workshops

Department of Commerce

Division of Energy Policy

1 North Capitol, Suj te 700

Indianapolis, Indiana 46204-2288

Contact: Dennis Harris, Program Coordinator

(317) 232-8982

Demonstration Window is a one-year state-funded program consisting of workshops to be conducted in each of 14 areas designated in Indiana. The workshops will train retired senior volunteers (from the Retired Senior Volunteers Program) to teach and demonstrate several weatherizing techniques to their peers.

Workshop participants will be identified through volunteers from Agencies on Aging. Volunteers from each community or neighborhood in the designated area will attend a workshop. The volunteers who receive training at the workshops will return to their peer group and one-on-one will demonstrate and teach weatherizing techniques such as the use of different types of caulking, water flow restrictors, and water heater jacket placements; the best and most costeffective methods and material types: the application of heat shrink plastic for storm windows; and the use of visqueen over windows where appropriate. Each householder is expected to supply his/her own materials. 
Illinois Educational Pilot Program

Illinois Dept. of Energy

and Natural Resources

325 West Adams, Room 300

Springfield, Illinois 62706

Contact: Carol Cavanaugh

(217) $785-3412$

The Illinois Department of Energy and Natural Resources (ENR) has developed an educational program to supplement the financial assistance provided by the Illinois federal Low-Income Home Energy Assistance Program (LIHEAP), administered by the Department of Commerce and Community Affairs (OCCA). The educational program consists of a ten-minute informational slide show that discusses low-cost and no-cost conservation tips. The slides are shown to Chicago-area clients while they wait to apply for LIHEAP assistance. These clients are also given a free packet of energy conservation materials.

This pilot program is a partnership between ENR and DCCA and uses federal funds from LIHEAP and the City of Chicago, which operates the Illinois LIHEAP application centers. Two utility companies, Peoples Gas Light and Commonwealth Edison, provide the audiovisual equipment and energy conservation packages. Over 4,000 Chicago-area residents were expected to be served by this program during the 1985-1986 heating season. 
Weatherize Homes In Portland (WHIP)

State Office of Energy Resources

State House Station $\$ 53$

Augusta, Maine 04333

Contact: Herb Sperry, Director

(207) 289-3811

Weatherize Homes In Portland (WHIP) is sponsored by the State office of Energy Resources. Since WHIP's inception, two workshops have been held: one in 1985 and one in 1986. A targeted area in Portland, Maine, was selected for the first pilot workshop in 1985. Through an existing community organization, homeowners were identified and mailings were made to promote a Saturday demonstration workshop as a way to teach weatherization techniques. No Iimit on the income level of participants was set. A free materials kit was given to all workshop participants as an incentive to encourage attendance.

At the first workshop, staff helped participants put together a free, customized kit for use in their homes. These materials included weatherstripping and fiberglass insulation, door sweeps and other anti-infiltration materials. Community action agency people were present at workshops to be a liaison for low-income people identified. The agency people can therefore direct the participants to appropriate programs or verify greater needs and enable them to get more materials. The success of the workshop was evaluated in two ways: evaluation by the Office of Energy Resources and an independent survey done through visitation or telephone communication with homeowners.

Others who have had key roles in the support and networking of this coordinated effort are the local gas and electric utilities, oil dealers, the State Housing Agency of Maine, a private bank in the state which makes 6\% loans for energy conservation improvements, community action agencies, and the State Energy Extension Service, funded by the U.S. Department of Energy.

In early spring of 1986, a second pilot effort for WHIP consisted of six workshops in two neighborhoods. The effort was funded primarily by the city of Portland, with support from local utilities and oil dealers. Also at that time, a workshop, "wow," was held in the rural town of Washburn, Maine. This workshop became a community effort where all of the supporting community entities put together a committee to organize and coordinate the workshop. The workshop was extremely successful and the participation level was high.

These workshops have generated interest in home energy audits. Some of the recommended improvements from the audits have been substantial enough to require loans to accomplish the improvements. Thus, besides the utilities, fuel oil dealers and state resources supporting the workshops, a Maine bank has also been involved by offering financial consulting services and low-interest loans for the retrofit materials and labor, where necessary.

The success of the pilot program has motivated a proposal to the State legislature to use a portion of Malne's compensation for oil excess charges as seed money for a statewide program using a similar format. 
Operation Insulation

City of Minneapolis Energy Office

(Coordinated with MinneGasCo)

330 City Hall

Minneapolis, Minnesota 55415

Contact: Sheldon Strom

(612) $348-5670$

In June 1985 a city-certified insulation program called 0peration Insulation was instituted. The City of Minneapolis Energy Office is responsible for administration and overall supervision of the program. MinneGasco contributes materials and labor costs up to $\$ 475$ per household.

Progran recipients are identified through three criteria: $125 \%$ of poverty; high gas (fuel) use, over 2,000 ccf gas/year; and fuel-b11l assistance cases. Also, because $70 \%$ of low-income families live in single-family and multifamily rental units, rental property owners are targeted. The recipients are contacted by staff from Community Assistance Programs (CAPs).

The program provides free energy audits and educational workshops, and antiinfiltration problems are emphasized. At the workshop, staff or volunteers from community action groups are present to 1) refer people to the appropriate agency or program, and 2) sign up participants to work out a fuel payment budget to put their annual utility bill on monthly payments (to be approved by the utility). The budget consultation and planning are done by the CAPs.

As of May 1986, 150 to 200 homes have received anti-infiltration measures. In the progran's first year, $75 \%$ of the first 50 who agreed to receive antiinfiltration measures and to do a budget are current in their payments. 
Energy Assistance Foundation

Illinois Power Company

P.0. Box A 1749

Decatur, Illinois 62526

Contact: Harold Powell, Executive Director

In December 1982 the Illinois Power Company incorporated the Energy Assistance Foundation to provide grants to grass-roots groups, such as the Jaycees, Kiwanis, and churches, to operate residential retrofit programs in their communities. The target income group is residents between $125 \%$ and $150 \%$ of federal poverty level. Priority is given to the elderly, handicapped and single-parent residents: no restrictions are set on the types of homes receiving services. The local organizations, not the foundation, ultimately make the final decisions on who receives the services. The foundation serves all of the utility's 11 service areas, which comprise $25 \%$ of the state of Illinois. Over 200 homes a year are improved through foundation grants.

Illinois Power Company provides energy audits, initial funding for the foundation's program, educational and promotional resources, and matching contributions of the utility's customer donations through a utility-bill checkoff system. As of May 1986, Illinois Power Company customers had contributed almost $\$ 27,000$ from the annual appeal made in a bill insert early in the year. The foundation administers the funds, coordinates program, does promotional work, and provides direction and guidance to the grass-roots organizations.

The program's success can be attributed to the multibased funding, the foundation's expertise, and the volunteers' enthusiasm for grass-roots operations. 
Westside Energy Co-op

825 W. 11th

Denver, Colorado 80214

Contact: John Procter

(303) 973-8207

In 1984, John Procter started Westside Energy Co-op to help the people in the very low-income district of Denver to reduce their energy dependence. The cooperative operates much like a community action agency (administers federal weatherization monies). To provide more services, Westside also conducts special promotional events to help weatherize homes and to educate residents on energy conservation. The promotional events are accomplished through the use of volunteers. Since 1984, federal assistance to westside has increased from $\$ 65,000$ to about $\$ 1$ million. However, these monies are not used for the special educational and training events sponsored by Westside.

Several methods are being used to assist and train the low-income people. Westside annually conducts a caulk-a-thon to teach people how to caulk their homes. Volunteers are relied on exclusively; last year's event attracted over 100 volunteers. Westside relies on various techniques to recruit volunteers, who come from all income levels. For example, they knock on doors in the community and ask to put a bumpersticker on the residents' cars to promote the event; however, this effort is also aimed at getting the residents' support. In 1986 Westside plans to add a similar event, a strip-a-thon, to teach people about weatherstripping.

Another activity, called a "Barnraising" event, is held to train the residents in the community to install conservation measures. Low-cost services that produce high-energy savings, such as replacing a broken window, wrapping pipes, repairing furnaces, and weatherstripping are stressed in the barnraisings. About 2 days of a staff person's time is required to organize the barnraising; to decide on the demonstration location, such as a home (or church, or school gym if many people are expected); and to have the supplies ready. The event is relatively inexpensive because there are no/few materials to buy (only those needed for the demonstration). The barnraisings and caulk-a-thons are promoted to volunteers as a fun way to meet friends, to help a neighbor and to learn something. Caulk-a-thons are held once a year and barnraisings are held about every other month.

John Procter stressed that volunteers must be adequately trained. For example, with the caulk-a-thon, the volunteers are trained for 2 hours to use a caulk gun. Mr. Procter also notes that organizations should not expect to have long term-support from the volunteers, but to use them for an event where they provide and receive some benefit.

Beyond these heavily promoted events that use a lot of volunteer support, Westside also bids on federal Weatherization Assistance Program contracts. 
Worcester Labor Coop

205 Millbury Street

Worcester, Massachusetts 01610

Contact: Richard Widak, Executive Director

(617) $757-2238$

Worcester Labor Coop is a nonprofit, private company reorganized in 1982 to perform energy-efficiency services as a business. Before 1982, the group was a nonprofit organization that performed energy-efficiency improvements with funds from government grants. When funding diminished in the late $1970 \mathrm{~s}$, the group looked for ways to continue operating and maintaining its original charter and mission to perform low-income housing improvements.

Worcester began its private business with help from a consultant group, Technical Development Corporation. Worcester developed a market profile and plan, operations plan, and bookkeeping system that allowed it to operate without low-income project grants. To be self-supporting, Worcester advertises in the telephone book yellow pages, bids on jobs, and bids on grants from utilities and government agencies for low-income conservation projects.

Annually, Worcester makes improvements in about 100 buildings. The work includes insulating, weatherstripping, repairing windows, and installing storm windows and anti-infiltration measures. 
The Metropolitan Energy Information System

3808 Paseo

Kansas City, Missouri 64109

Contact: Peter Dreyfuss, Executive Director (816) $531-7283$

The Metropolitan Energy Information Center (MEIS) is the only comprehensive energy service agency operating in the metropolitan area of Kansas City. Its mission is to provide information and services that will involve people individually and collectively in managing and controlling energy use. In the summer of 1983, the MEIS was incorporated as a not-for-profit corporation separate from the City of Kansas City, where it had been operating since 1981 .

During the past three years, the Center has established itself as the central source of information on ali aspects of energy conservation and alternative energy. It is the clearinghouse and coordinator of information and services to other energy agencies and groups and is the focal point for discussion and implementation of new energy programs. The Center also develops and implements specific conservation programs in areas of demonstrated need. Low-income residential retrofits are one of the services offered by the Center. It is currently operated by four full-time paid professional staff under the direction of an eight-member volunteer board.

The Center's current programs are supported by a combination of public and private funding. The Center receives support from area corporations and foundations, from local and state government, and from the United way. The level of support reflects the importance with which energy conservation is perceived in the area. Currently, the Center's service area includes two metropolitan communities, Kansas City, Missouri, and Kansas City, Kansas, plus five surrounding counties in the two states.

Hundreds of volunteers, neighborhood groups, and local service organizations are engaged in the various projects for the Center. The Center operates on a $\$ 250,000$ budget, which includes donations, and has a $\$ 750,000$ loan fund.

The executive director believes the Center's success is due to persistence, broadening of the funding base, and commitment from corporate businesses and society to promote energy conservation. He feels that it is necessary to demonstrate that there really is a payback when energy-conserving technology is used and when education on energy-saving techniques is carried out. 
Weatherization Project for Low-Income

Christians for Urban Justice

563A Washington Street

Dorchester, Massachusetts 02124

Contact: Leslie Jackson, Operations Manager, Christians for Urban Justice

(617) $825-6080$

In 1984, the Christians for Urban Justice founded a community project to help low-income households reduce energy losses. The objective was to use stepby-step instruction to teach householders in poorer communities to use materials and techniques to reduce their energy use and thus their energy costs.

The project operated by training a nucleus group in a parish. That group was then responsible for educating and training others to use insulation, caulk and weatherstripping, and to repair windows. Project staff produced a stepby-step instruction booklet that was sold below cost at training sessions held in the churches. The Christians for Urban Justice did not distribute any materials.

The project did not set any eligibility limitations based on income levels; any request by needy persons was met. Anyone who attended a workshop and expressed a need for assistance received the services. The promotional efforts for this project were low key, primarily word of mouth, announcements in the churches, and direct referrals from local churches. Project staff also tried to involve outlying suburban churches that had financial capabilities for providing funding.

This project, which provided the knowledge and taught the application of energysaving technology, was successful and filled a need while it was functioning. The project is no longer operating because the metropolitan, state and federal government projects in the area are now we 11 coordinated and networked, and therefore can better fill the low-income needs at this time. 
Furnace Retrofit

Lutheran Housing Corporation

1217 Hayden Ave.

Cleveland, Ohio 44110

Contact: Rick May

(216) 651-0721

The Lutheran Housing Corporation (LHC) is a nonprofit religious organization that operates like a community action agency, in that it administers many government-supported weatherization programs. LHC's current efforts are directed toward performing furnace repairs. In 1985 LHC repaired 220 furnaces of low-income residents at an average cost of $\$ 660$.

LHC has received grants from the ford Foundation and Standard $0 i 1$. The grants are used to supplement federally funded programs. However, these grants have diminished over the years and are not considered by LHC to be long-term sources of support. Faced with diminishing federal and foundation funds, LHC has started to look to utilities for future sources of support. 
Thrift Store and Storm Panels

Office of Human Concern

Rogers, Arkansas 72757

Contact: Bill Brown

(501) $636-7301$

Since 1978 the Office of Human Concern, a community action agency, has been fabricating storm windows for the homes it weatherizes through federal programs. The agency also operates a successful local thrift store.

Storm Panels - In 1978 the agency began fabricating storm windows for the homes it weatherizes. These windows have an aluminum-type frame with a screen that is similar to that used on screen doors. They are installed from the inside of the home and are especially useful in mobile homes, where many other types of storm windows will not work.

Currently, 7 people are employed in the agency's residential retrofit program. These workers also fabricate the storm windows during slack time, which allows the agency to retain the employees during slower times. By fabricating the storm windows instead of purchasing them, the agency saves an estimated at $\$ 10$ to $\$ 15$ per unit.

The agency has considered marketing the storm panels to the general public, but because of the increased threat of liability, they have decided against it. However, the design and fabrication of the panels are relatively simple and could be easily replicated by other weatherization-type agencies. The agency has taught other neighboring agencies to fabricate these windows.

Mr. Brown stated that the storm windows were designed in response to the need for a storm panel that would work on mobile homes and because of a large demand for the panels. The agency has an architect on staff plus other personnel who are exceptionally creative and were critical to the development of the panels.

Thrift Shop - In 1976, the agency started selling second-hand merchandise on a small-scale basis. The shop was run by elderly volunteers and all merchandise was donated. Two years ago, the thrift shop moved into a 5,000-square-foot buflding in the downtown area. The shop is still run in part by volunteers and all merchandise is donated. Last year the thrift shop made $\$ 85,000$ in profit. This money is channeled back to the agency and used in programs to help the elderly, such as meals on wheels, transportation services, etc.

One contributing factor to the shop's success is that many senior citizens, to whom the shop is targeted, live in the community. These people donate much of the merchandise and also purchase what others have donated. Another contributing factor has been the agency's special effort to publicize that the shop's profits are channeled back into senior citizen programs. Publicity in the form of media stories has also helped the shop. The agency advertises in the local paper and sends out flyers to request donations. The ads always state that the profits will be used to help senior citizens. 
R Brite Windows Company

Project Home Inc.

214 S. Madison

Madison, Wisconsin

Contact: Jane Goodrich

(608) $258-4800$

Project Home is a nonprofit community action agency that has been successful in supplementing its federal funds by purchasing and revitalizing a window manufacturing company, R Brite Windows, which was going out of business. Project Home's mission is to weatherize the homes of the elderly and disabled and to create jobs for the traditionally unemployable--minorities and women.

Project Home was able to secure contracts from many of the governmental agencies administering weatherization because R Brite uses Humphrey windows, which were set as the standard for windows installed through government contracts. Government contracts specify "Humphrey or better." The windows are built from extruded aluminum, a high-quality material for storm windows. R Brite has exclusive rights to these materials for the area. Project Home was also able to sell the windows on a sliding-scale basis to the general public. It has not marketed the windows to the general public, but has relied on word of mouth to sell them.

$R$ Brite Windows was operated as a separate corporation from Project Home with a separate Board of Directors. The effort was so successful that the company was recently bought out by the workers who helped make the company a success. The workers have renamed the company SUMPREA Air Tight windows and incorporated the company as a nonprofit concern.

R Brite Windows was originally started by the local Community Action Committee to employ underpriviledged workers, but lost a lot of money. In 1984, Project Home purchased the business for only $\$ 1,800$, which included all tools and materials. The funds were secured through the creamer foundation--a national foundation made up of cheese wholesalers. This foundation donates $\$ 10,000$ yearly to Project Home. A member of the foundation works for Project Home and helped obtain funding. R Brite Windows' success story had its ups and downs. At one point, $R$ Brite Windows was in debt $\$ 40,000$, but many of the risks that were taken paid off.

Jane Goodrich, a Project Home representative, stated that the two reasons vital to the success of the business were timing and extremely hard work. In 1984, Wisconsin received a one-time federal $\$ 100,000$ grant that subsidized minority and underpriviledged workers. Part of that money was used to pay the wages of the workers of $R$ Brite Windows for one year. After that subsidy, the company was able to become self-sufficient. Many workers stayed on through rough times after that year because they could not find employment elsewhere, even with their new skills. Profits resulting from $R$ Brite Windows were channeled back into the business or were used to help weatherize more homes.

Project Home is in the process of developing another spin-off weatherization business to supplement its federal funding. One possibility being considered would provide assistance to homeowners who are over the maximum income set by the Weatherization Assistance Program (WAP). 
Wayne-Metropolitan Community Services Agency

Wayne-Metropolitan Community Action Agency (CAA)

3715 W. Jefferson

Ecorse, Michigan 48229

Contact: Luther Flanagan, Executive Director

(313) $843-2550$

Or contact: Denise Brasille, Mgr. of Econ. Development

The Wayne-Metropolitan Community Services Agency created two spin-off businesses to secure more funding in order to continue to provide energy retrofit services and to create jobs for low-income people. Federal funding was expected to decline and the agency viewed foundation grants as one-time relief.

RE-NU Wood and Metal Stripping, the first spin-off, was started in 1984. RENU is a smali-scale business that employs a maximum of seven people. RE-NU markets its services to three market segments: retail, commercial, and residential, its primary market. The business has not yet paid for itself, but contract negotiations currently are being conducted with chrysler corporation. In an adjacent county, a sister company that is owned by a community action agency (CAA) has a contract with Ford Motor Company and is doing quite well.

The franchise for Spring Tite windows, the second spin-off, was purchased by Wayne-Metropolitan CAA in early 1986 through a seed-money grant from the city and through some of its own funds. The franchise secures the sales of patented storm windows in one county, but because no other franchises exist in the area, they are able to sell to half the state. The windows, which recently had been developed and patented, offer several benefits to low-income residents:

1. The windows are spring loaded to fit into any existing window, even those not quite square.

2. These windows are installed from the inside. Labor costs are greatly reduced because of the ease of installation, which can be done by the residents. This feature greatiy reduces labor costs in buildings taller than one story, including apartment complexes.

3. These windows can be removed when an occupant leaves the home, an important benefit to renters.

The overall cost savings to the agency from these windows is about $40 \%$. The manufacturer guarantees the windows for 20 years. Wayne-Metropolitan orders the window frames from the franchise headquarters in Illinois. The agency then installs the glass, purchased locally, and completes the window construction. Currently, three workers are on call to construct windows. Salespersons will be employed for three months on salary plus commission (5\%), after which they will be on straight commission of $15 \%$. 
Custom Home Improvement Association

Comunidad de Amigos

Sheboygan, Wisconsin

Contact: Lucio Feuntey

(414) $459-2784$

Custom Home Improvement Association (CHIA) was started in 1983 as a for-profit spin-off of Comunidad de Amigos, a community action agency. CHIA manufactures windows that are sold primarily to Weatherization Assistance Program (WAP) subconstractors. According to CHIA, WAP coordinators purchase the windows primarily because of their high quality.

Comunidad contributes office space and gave CHIA a $\$ 15,000$ start-up grant. The remaining needed funds were obtained through a bank loan, which is almost repaid. CHIA's annual operating costs are $\$ 120,000$ and revenues are $\$ 140,000$, leaving a $\$ 20,000$ annual profit. Currently, CHIA employs four part-time assemblers.

Lucio Feuntey, manager, gave several hints for developing a successful spinoff business from a nonprofit organization:

- Hire a strong full-time manager to build the business.

- Obtain and retain government supply contracts.

- Hire workers skilled in the technical aspects of the work and in workefficient techniques.

Lucio Feuntey notes that when the spin-off first started, it lost money because the production workers were also trying to market the windows to other WAP subcontractors, and CHIA had no full-time manager. A manager was hired, but because he was on a commission basis, his compensation did not provide an adequate incentive. CHIA hopes to begin marketing to the general public again, but needs a source of startup funds to pay an experienced manager. 
Economic Opportunity Agency of Washington County

2325 N. Gregg

Fayetteville, Arkansas 72703

Contact: Bruce Davis

(501) $521-0528$

This community action agency began manufacturing two types of storm windows about eight years ago because its suppliers did not make windows that met its needs. The only windows available were of low quality and difficult to obtain. As a result, the agency began to order certain parts for the windows and to manufacture the windows itself.

The agency saves about $50 \%$ on the overall cost of the new windows installed. Manufacturing these windows also allows the agency to keep workers on staff when residential retrofit work is slow. Last year they produced about 1,000 windows with a crew of 3 (regular staff) workers and retrofitted 115 homes.

The agency currently sells a few units (windows) per year to the general public, who see the retrofit jobs done on homes in their neighborhood and want the same windows installed. Although these sales are profitable, the agency currently does not make an effort to market these windows. However, the agency is considering this option because of possible budget cuts. The agency is also considering using a recently purchased blower door, a device to estimate a home's infiltration rate, on a "for-hire" basis to supplement its federal funding. 
Syracuse Energy Service Company, Inc.

Peoples' Equal Action and Community Effort (PEACE)

Syracuse, New York

Contact: Joan Brooks

(315) $470-3300$

The Syracuse Energy Service Company is a business spin-off of PEACE, a large community action agency that completed about 1,500 federal weatherization contracts last year. Energy Service was incorporated in September 1984, and became operational in June 1985. Energy Service received a $\$ 71,000$ model project grant for training and assistance from the U.S. Department of Energy. It also received a $\$ 40,000$ grant from the State Energy office to put together business and loan partnerships to become more self-sufficient. The company is seeking nonprofit status.

Energy Service currently targets landlords who own energy-inefficient buildings that have a payback potential of less than 5 years on the weatherization materials installed and a high potential for energy savings. Energy Service is primarily assisting residents (rental) who are eligible for federal weatherization assistance in order to establish a track record in the eyes of the property owners.

In the long-term, the company plans to develop a loan pool that will enable landiords to borrow money at lower-than-market rates. This loan pool will be obtained from utilities, banks, and possibly oil overcharge funds that will loan Energy Service money at $0 \%$ interest. Energy Service will leverage these monies and charge a percentage of cost to the landlords for providing them with a "packaged" service, which will include conducting an energy audit, coordinating the different contractors to perform the work, inspecting the work, identifying residents who are eligible for federal assistance, and providing lower-thanmarket loans.

Energy Service expects to have a payback period of about 3 years. To date, the company has completed one 15-unit apartment complex and has 5 other buildings ( 10 to 50 units each) at various stages of completion. The company contracts for all types of energy-efficiency improvements, which it subcontracts out to other companies. 
American Indian Economic Development Council

North American Indian CuTtural Center

1159 Lakeshore BIvd.

Akron, Ohio 44301

Contact: Joe Myers

(216) $374-6973$

The North American Indian Cultural Center is a nonprofit organization that helps support, among other programs, the federal Weatherization Assistance Program (WAP). In 1984, the Center created a for-profit company called the American Indian Econonic Development Council in order to obtain less-expensive long-term leases for vehicles needed to transport materials for their weatherization program. The leasing of new, quality vehicles is expensive and risky unless a long-term lease is signed. Many agencies are reluctant to sign such leases because most of their federal contracts can be withdrawn on 30 days notice. However, older vehicles are more expensive than new vehicles to maintain.

The Council signs long-term (3- to 4-year) leases with an automotive company for a large number of vehicles and receives a preferential rate. This rate is passed on in part to nomprofit organizations that in turn lease from the Council. The Council makes money on each vehicle it leases and saves substantially on its own vehicle costs. The council also leases vehicles to employees of these nonprofit agencies if the employees meet certain criteria.

To further supplement its federal weatherization monies, the cultural Center relies primarily on fund raisers, usually using well-known singers. Volunteers and callers, who work on commission, conduct a telemarketing campaign to encourage area businesses to advertise in the concert's program. A telemarketing campaign is also used to sell tickets to the concert, and the fact that these monies go to help the poor is stressed. Overall profits usualiy amount to about $\$ 10,000$.

Currently, the Council has a fleet of 21 vehicles for the Cultural Center's weatherization program and has 4 to 5 other contracts with other nonprofit organizations. The Council plans to start seeking contracts with other agencies soon. 
Weatherization Program

People's Natural Gas Company

1414 West Broadway

Council Bluffs, Iowa 51501

Contact: Ron Koopmeiners, Director/Administrator

(712) $325-3004$

People's Natural Gas (PNG) Company started a low-income residential retrofit program in 1982 because no local community action group was functioning at the time. PNG also was concerned that its customers were wasting energy. The program improves approximately 150 houses per year. with priority going to senior citizens and handicapped in both urban and rural areas. The service includes a free audit, insulation, caulking, weatherstripping, window repair, and educational literature. A limit of $\$ 2400$ per house is set; an average of $\$ 1150$ to $\$ 1200$ is spent per home, not including PNG's contribution of educational materials and the labor cost of its energy auditors.

PNG's customers contribute about $25 \%$ to $30 \%$ of the program's cost through utility-bill check-off donations. PNG contributes $\$ 40,000$ to $\$ 50,000 /$ year for administration and technical assistance.

The Director believes the program is successful because there is open communication among all the involved parties: utility, customers, program recipients, the state, and the local community action agency that is now actively functioning. 
SCAT 33-500 Program

United Illuminating

P.0. Box 1564

New Haven, Connecticut 05606

Contact: Robert Brown

(203) $787-7200$

The SCAT 33-500 low-income assistance program is coordinated by United Illuminating (UI), a medium-sized electric public utility. The goal of the project is to save recipients $33 \%$ annually on their energy bills and to weatherize 500 single-family and multifamily dwellings. The program is administered by 12 organizations that make up the Southern Connecticut Action Team (SCAT).

Funding for this program was obtained through a $\$ 500,000$ grant from the state of Connecticut in 1985, and UI contributes about $\$ 200,000$ of its own funds. About $\$ 550$ is spent per home on retrofit materials.

The Community Action Agency of New Haven (CAANH) is the prime contractor for installing the retrofit materials. Low-income elderly and handicapped residents, and multifamily dwellings are given first priority. Residents are identified through UI's fuel-assistance lists and wajting lists for the CAANH Weatherization Assistance Program (WAP). 
Elders Helping Elders

New Opportunities for Waterburg

Selden Street

Berlin, Connecticut 06037

Contact: Toni Hearst

(203) $575-9799$

New Opportunities for Waterburg (NOW) is one of ten community action agencies that contract with Northeast Utilities to provide weatherization services to low-income utility customers in NOW's community action territory. NOW established the Elders Helping Elders program as an expansion of a previous low-income weatherization program started in 1984. The previous program targeted any low-income customer, whereas the Elders program targets elderly low-income customers. Funding provided to NOW from Northeast Utilities for 1986 is about $\$ 200,000$, and 500 homes are expected to be weatherized.

NOW targets residents who are under $200 \%$ of federal poverty level, although anyone needing assistance according to a CONNSAVE audit is eligible for NOW assistance. CONNSAVE is a nonprofit consortium of electric and gas utilities that perform Connecticut's Residential Conservation Service (RCS) activities. The types of conservation measures provided include weatherstripping, caulking, insulation, storm windows, water heater wraps, and door sweeps. The total cost of these measures usually is about $\$ 500$ per home. When more extensive repairs are needed, the resident is referred to other government agencies for further assistance.

NOW is involved with the recently created the Governor's Energy Advisory Committee. The State of Connecticut created the committee to unite representatives from state offices, utility companies, community action agencies and nonprofit groups in order to promote interaction and cooperation among groups concerned with the energy needs of the poor. The committee meets monthly and has been quite successful according to NOW. 
Direct Weatherization

San Diego Gas and Electric Company

P.0. Box 1831

San Diego, California 92122

Contact: Roger Munson

(619) $280-3400$

The Direct Weatherization Program, sponsored by the San Diego Gas and Electric Company (SDG\&E), was mandated in 1983 by the California Pubic Utilities

Commission. Currently, the criteria for eligibility are single-family homes (up to 4-plex) and incomes of up to $150 \%$ of the federal poverty level. Assistance includes hot-water-heater wraps, caulking, weatherstripping, glass repair, and low-flow shower head installation. The utility contracts with both local community action agencies and with private contractors to improve the homes.

In 1985, 2900 homes were weatherized at a cost of $\$ 2.2$ million. The average expenditure per home has been about $\$ 400$ (plus overhead). During 1986, the utility intends to improve 3,000 homes with a budget of $\$ 1.5$ million. The number of homes targeted is down by 1,000 from last year because with the large number of assistance programs offered throughout the state, fewer homes are left to receive assistance.

Since the inception of the Direct Weatherization Program, SDG\&E has improved approximately 15,000 low-income homes at a cost of about $\$ 8$ million. Media campaigns have reached most of the customers who might respond to advertising, so San Diego Gas and Electric has undertaken a door-to-door campaign in lowincome communities to identify eligible residents. Because no overall account is kept across the state of which homes are serviced by the utilities, some duplication of efforts may occur. 
Operation Assist

Alabama Gas Corporation

P.0. Box 1351

Montgomery, Alabama 36192

Contact: Jim Eason, Consumer Affairs

(205) $326-8100$

Alabama Gas Corporation (AGC), in cooperation the with the Alabama State Employment Service, conducted a community service program called operation Assist for two months in the summer of 1985. Because of the program's success, AGC is going to conduct the program again for two months during the summer of 1986. The program, funded totally by AGC, provides free home energy-efficiency improvements to low-income families within AGC's service area.

Services provided by the program in 1985 included window caulking, weatherstripping, repairing holes or gaps in walls, and providing door sweeps and frames for plastic sheeting around windows. The workers brought the sheeting and showed the residents how to install it when temperatures dropped. A booklet containing winter energy conservation tips was also left with the resident. The workers also looked for signs of structural damage to roofs and foundations in order to report those needs to other community agencies that perform major repairs.

The program was available to anyone who has all or part of his/her gas bill paid by the Low-Income Home Energy Assistance Program (LIHEAP). Also eligible was anyone who is part of the service continuation program (SCP), which establishes a set payment plan for low-income customers who are unable to pay their utility bills.

Program recipients were identified through LIHEAP and SCP lists and were contacted by letter from AGC. The letter explained the services and notified the recipients of an upcoming visit from workers. Community awareness was essential to the program's success because many people are suspicious of "free services." Therefore, AGC asked community leaders to inform people of the program and to encourage them to take advantage of the service.

The State, using specifications set by $A G C$, hired work crews of teenagers through the Alabama State Employment Service. Thirty-five foremen, 38 supervisors, and 286 installers were hired and then trained by AGC. The teenagers improved 14,571 homes. AGC paid the workers' wages and received a $50 \%$ tax credit for the first $\$ 3000$ paid to each supervisor and an $85 \%$ tax credit for the first $\$ 3000$ paid to each of the installers. Last year, the utility inspected every 20 th home, but planned to inspect every 5 th home during the summer of 1986 . 
Arkansas/Louisiana Gas Company

P.0. Box 751

Little Rock, Arkansas 72203

Contact: Tanya Amo

(501) $370-2702$

The Arkansas/Louisiana Gas Company program is scheduled to begin in the summer of 1986. The program is very similar to the Alabama Gas Company low-income residential retrofit program except that this program uses the community to a greater extent. The gas company is sponsoring the program to better its image and to help low-income customers decrease their utility bills. The gas company will also sponsor workshops to help low-income people develop resume writing and interview skills.

The gas company program will hire low-income youths from local schools to improve homes of low-income gas customers. These youths will be trained to install materials such as caulking, door sweeps, weatherstripping, and plastic window covering, and to instruct the resident on further energy-efficiency tips. Customers will be identified by the gas company's fuel-assistance lists, and from lists and referrals for the state Low-Income Home Energy Assistance Program (LIHEAP).

The gas company estimates that it will spend about $\$ 100,000$ during this $10-$ week program, improving 1,000 homes at an average expenditure of about $\$ 100$ per home. 
Chugach Assistance for Real Energy Savings (CARES)

Chugach Electric Association

P.0. Box 19630

Anchorage, Alaska 99519-6300

Contact: Sue McCauley, Energy Mgmt. Supervisor

(907) $563-7494$

The Chugach Association for Real Energy Savings (CARES) is a low-cost energy loan program started in February of 1986 by the Chugach Electric Association, a publicly owned electric cooperative. The loan program is available to all members of Chugach Electric.

The program offers $5 \%$ loans to its members to finance home energy-efficiency improvements. Money for the loan program is available under a program offered by the federal Rural Electrification Administration (REA), which provides financial assistance to eligible public electric utilities. REA allows its borrowers to defer part of the principal payments on their oldest REA loans and to use the money to make energy-efficiency-improvement loans to cooperative members. For the next two years $\$ 1.1$ million a quarter is available for the CARES program. Loan amounts will range from a minimum of $\$ 3,000$ to a maximum of $\$ 10,000$. The program is managed by Chugach Electric, which contributes $\$ 13,000$ for administrative staff salaries.

Although the program is new, 600 to 800 homes are expected to be improved the first year. Since the program began operating, 244 loan applications have been received. The loans will be processed on a prioritized basis. Top priority will be assigned to members requesting an electric-to-gas heat conversion in owner-occupied, single-family residences. The second priority will be for members requesting energy retrofit measures for owner-occupied, single-family residences. All other requests will be assigned a priority of three, the lowest level. Individually metered and heated condominiums and townhouses will be treated as single-family residences. Duplexes and larger multifamily housing will be considered commercial property. Mobile homes will not be eligible unless they qualify as real property (the mobile home is permanently affixed to the property and the home is assessed as real property rather than personal property).

A CARES loan applicant must own the building in which the energy improvements are to be made, and the building must receive electric service from Chugach Electric. An energy audit (conducted for no charge) and a review of the project's estimated costs determine the amount of the loan. Members may choose their own contractor or do the work themselves, but they must have two bids and the work must be inspected after it has been completed. 
Southern California Edison

California Public Utilities Commission

P.O. Box 800

Rosemead, California 91770

Contact: Mr. Nall

(818) $302-3693$

Southern California Edison (SCE) operates a low-income home weatherizing program that was mandated in 1983 by the California Public Utilities Commission. Other major utilities in the state have similar programs, but they operate independently. Each year, SCE provides conservation assistance to about 500 low-income customers. Assistance includes an initial audit, weatherstripping, ceiling insulation, and air-duct insulation at a cost of about $\$ 500$ per home.

Eligible residents are identified from the Low-Income Home Energy Assistance Progran (LIHEAP) and fuel-assistance lists. Many residents al so hear about the program by word of mouth. First priority is given to senior citizens and the handicapped. SCE contracts out all the conservation work conducted for its program. Community action agencies perform most of the home energy audits for SCE and bid on much of the conservation work.

Funding for the program has remained about the same since 1983. The utility's main problem in operating the program has been the difficulty in identifying eligible customers who have not already been assisted by government programs or other utilities. As a result of the lack of coordination among various low-income conservation efforts, the utility feels that some duplication of effort may be occurring. 
Weatherize Boston

1 City Hall Plaza

Boston, Massachusetts 02201

Contact: Jill Kolva

(617) $725-3307$

Weatherize Boston is a cooperative effort of public and private entities to provide coordinated, leveraged services to all homeowners and tenants in the Boston Metropolitan area. About 40\% of Boston's householders lack attic insulation, storm windows and doors; $90 \%$ lack other cost-effective conservation measures that would cut fuel bills by $20 \%$ to $30 \%$. Weatherize Boston's combination of neighborhood outreach, workshops, free kits, low-cost energy audits and attractive financing makes conservation easier and more likely to occur.

The program differs from other previous efforts to educate the househoider in energy conservation by its methods and tone of outreach, by the motivating slant of its workshops, and by its finance options. By coordinating the cooperation and participation of different groups, Weatherize Boston effectively maximizes the strengths (talents) and resources of all groups.

Weatherize Boston relies on community-based outreach and extensive use of volunteers for marketing. The Office of Neighborhood Services consults with leaders of community groups to identify "good workers," who are then recruited for telemarketing or door-to-door outreach to publicize a workshop and persuade residents to attend. A free conservation kit worth $\$ 25$ is offered to attract workshop participants. Those who install the materials themselves become eligible for an additional $\$ 25$ worth of materials that are installed by an energy auditor. Those who do not install the kit have only the kit installed for them as part of their audit. By installing the materials, workshop participants also learn how easy energy home improvements are and become comitted to the idea of energy efficiency.

An energy audit or "personal home survey" is scheduled for participants at the workshop by the Fair Share Development Corporation (FSDC), a member of the Community Energy Partnershop (CEP). This scheduling approach allows the participants to meet their auditor, ensures a speedy delivery of the audits and gives them a choice of date and time for the audit. The auditor analyzes the home for energy waste, makes conservation recommendations, inspects and installs the kit materials, explains Weatherize Boston's financing options, helps participants fill out pre-application forms for financing and gives them a list of approved contractors. These actions and assistance at this time increase the percentage of particpants who actually have energy-efficiency measures installed. All improvements financed by this program are inspected to assure that a quality job has been done.

The first workshop, heid November 1985, was successful in attracting participation. About 300 to 500 people were targeted for attendance in the community where it was held. About $12 \%$ of these people participated, and $70 \%$ of the participants signed up for audits. This translates to a participation rate of over $8 \%$ of the targeted audience. Low-income participants are directed to the Weatherization Assistance Program during the workshop, insuring that the most needy participants get free weatherization assistance. 
Other key participants in Weatherize Boston include Boston Edison, which contributes $\$ 25,000$ to the salary of the outreach director: Bay Banks, Inc., which provides loans for Energy Conservation Bank; and the Bank of Boston, State Energy Office, and State Office of Communities and Development, which assisted with the planning program.

Weatherize Boston's goal is to continue the program for three to four years until most Boston Neighborhood communities have been reached. However, a $30 \%$ basic funding cut occurred as of July 1, 1986, from the Community Development Block (CDBG) grant funds. The program will have to seek alternate funding sources to continue the program as planned or cut back the services and materials offered. The CDBG contributes most of the money for workshop and material costs. 
Hand In Hand

Oklahoma Gas and Electric Company

P.0. Box 321

Oklahoma City, Oklahoma 73101

Contact: Dick Banks

(405) $272-3580$

In July 1984, Oklahoma Gas and Electric (OG\&E) Company developed Hand-In-Hand, a low-income residential retrofit program. OG\&E voluntarily developed the program to help elderly customers reduce their utility bills. The program employs "senior citizen contractors" to perform energy-efficiency services for other senior citizens. To be eligible for the services, the senior citizen resident must own his/her home and be within the utility's service district.

The utility uses senior citizen contractors because they work well with and relate to senior citizen clients. Senior contractors also have been found to be a valuable source for client referrals. Currently, 50 senior citizen contractors work for the utility. These seniors were recruited by OG\&E through social service agencies and church groups. Most of these senior contractors have prior experience in carpentry, but OG\&E trains them further.

Since the program began, 3561 homes have been improved. A full range of services and materials are provided by the program, including audits, weatherstripping, caulking, broken glass replacements, reglazing of windows, water heater jackets, insulation (insulation contractor), and minor repairs that will improve the home's energy efficiency. The maximum allowable expenditure per home is $\$ 500$. In 1986 about $\$ 816,000$ has been budgeted for the program through $O G \& E$. 
Baltimore Energy Alliance Program

Baltimore Gas \& Electric Co. P.0. Box 1475

Baltimore, MD 21203

C. Miller, Civic Affairs Rep. (301) 234-6541

City of Baltimore

920 East 25th Street

Baltimore, MD 21218

Richard Au11, Chief of Energy

Weatherization Program

In September 1983 Baltimore Gas and Electric (BG\&E) Company and the City of Baltimore started a joint partnership program, the Baltimore Energy Alliance Program (BEAP), to provide permanent conservation and roof insulation services. As of May 1986, 6,400 homes have been improved in Baltimore through this program. (Recognition of the "6,000th roof" received media coverage.) In 1986, BEAP expects to improve 1200 to 1500 homes.

BEAP is targeted to the low-income households to supplement Department of Energy (DOE) and Health and Human Services (HHS) programs using the Maryland Assistance guidelines of $150 \%$ of poverty. City employees are trained to install the conservation materials; no volunteers are used. A $\$ 400$ maximum is set per job but averaging is allowed, so homes requiring more than $\$ 400$ in materials and labor can be serviced because of the offset from homes requiring fewer services. BEAP provides retrofit roof insulation, anti-infiltration work, and furnace repairs or replacement.

The City of Baltimore administers the technical aspect of the program under the direction of Richard Aull. Mr. Aull is responsible for purchasing materials in quantity buying with other programs, storing materials in city warehouses, scheduling the services, supervising employees, ensuring quality control, interfacing with BG\&E, and managing insurance and other such business needs as the project requires.

BG\&E has contributed the following to the project: 1-year warranty on replaced gas-fired furnaces; re-imbursement labor for 11 cjty employees; loan of 2 one-half ton vans for transporting materials; 1 Econoline van; maintenance on the vans; a computer; and energy audits on homes. The total package from $B G \& E$ is $\$ 250,000$ per year. The social service agencies administer the applications and identify participants.

The key elements of success in this program are the expeditious central purchasing and installation of the conservation materials, the project workers' expertise, and the utility's funding to ensure cash flow. The number of homes improved in this program quantify its success in supplementing the DOE and HHS programs. 
Weatherization Residential Assistance Program

Potomac Edison Company

Downsville Pike

Hagerstown, Maryland 21740

Contact: Jo Mullendore, Supervisor Residential Activities (301) $790-3400$

In November 1985 the Potomoc Edison Company began full-scale operation of the Weatherization Residential Assistance Program (WRAP). The program's objective is to help the utility's low-income customers cut their electricity costs for the long term by providing energy retrofit services. The philosophy is that permanent energy-efficiency improvements save money for the recipients every year and reduce generator demands.

The utility provides materials and funds for installation to eligible customers. volunteers are not used in this program. Eligibility is determined by local weatherization agencies operated through Human Resource Development Commission Offices in the three state areas involved: Western Maryland, Eastern West Virginia, and North Central Virginia. The state guidelines and energy assistance eligibility lists from federal Weatherization Assistance Programs (WAPs) are used to identify recipients.

Each residence is allowed up to $\$ 500$ for materials and labor for the longterm measures. In addition, each residence receives free energy audits, insulated water heater jackets, flow restricting shower heads, door sweeps and post-insulation inspection. The objective is to install as many major energy-saving materials as possible for the money.

The goal of WRAP is to improve 550 homes in a two-year period. Thirty homes were retrofitted in a pllot program in 1984. In that program, no dollar limits were set in order to determine a limit that might be needed for the remaining homes. The program has been enthusiastically accepted. Two problems encountered are that it is sometimes difficult to obtain landlord permission on multifamily rental residences, and the process of identifying recipients through inspecting the installation is taking longer than the expected six months. 
Community Conservation Program

Potomac Electric Power Company

1900 Pennsylvania Avenue Northwest, Room 528

Washington, D.C. 20068

Contact: Gwen Hawkins, Program Manager

(202) 872-3287

Potomac Electric Power Company (PEPCO) established the Community Conservation Program (CCP) in mid-1983 to offer its senior citizens and low-income customers free assistance in installing energy conservation measures in their homes or apartments. This progran was initiated specifically to help those customers reduce their energy bills and to respond to the concerns of public service commissioners of Washington D.C. and Maryland that the customers most in need of conservation services often do not use the conservation programs available.

The CCP contracts with community-based organizations (CBOs) (similar to community action agencies) to provide energy conservation education for the target groups and to install the necessary energy conservation improvements. CBO contractors are selected through a competitive process: a proposal request is sent out to as many as 200 organizations; the CCP director holds 2 open meetings to answer questions and to discuss any program issues; proposals are submitted; and contracts are awarded. Applications are judged on the CBOs' past work, operations and education plans, the size of the target group within the CBOs' area, and the CBOs' ability to obtain matching funds. A CBO contractor must also commit to a definite number of units to be weatherized, must outline its financial arrangements, and must meet standards for the materials it uses. Finally, the CBO contractor must obtain permission from the program recipient to track the energy use in the residence after the conservation measures have been installed.

PEPCO trains the people designated by the CBO to install the conservation measures, and provides technical and management assistance to the contract recipients. PEPCO also performs energy audits and inspects at least $50 \%$ of the installations. The CBO may obtain matching funds from government programs or agencies that provide funds for weatherization and rehabilitation or from private-sector businesses, such as banks or foundations.

Benefits of the program include energy savings, both to the utility and to the program recipients; job skills developed; economic growth in the community through jobs, material sales, and more cash flow for consumers; and energy consumption tracking in residential sectors. In 1983, 500 homes were improved. The goal in FY 1986 is to weatherize 3,300 residences; of these 1,700 will be major rehabilitation, which can cost up to $\$ 1600$. The low cost range of work is $\$ 70$ to $\$ 200$ per residence. 
APPENDIX B

BIBLIOGRAPHY 
APPENDIX B - BIBLIOGRAPHY

The Bibliography is organized into five sections: 1) community organizing/planning, 2) fund raising by community groups or other foundations, 3) recruiting, training and managing volunteers, 4) proposal writing to corporations and foundations, and 5) sourcebooks.

\section{COMMUNITY ORGANIZING/PLANNING}

Beigel, D. E., B. K. Shore, and E. Gordon. 1984. Building Support Networks for the Elderly. Sage, Beverly Hills, California.

Bjttman, M. 1984. "Costly Caulks - When Do You Need Them?" Popular Science.

Bureau of Community Energy. 1982. Considerations for Transferring the Pennsylvania Weatherization Program Delivery System to the Private Sector. Program Development Division, Bureau of Community Energy, Harrisburg, Pennsylvania.

Caftel, B. J. 1978. Community Development Credit Unions: A Self-Help Manual. National Economic Development Law Project, Berkeley, California.

Cassidy, R. 1980. Livable Cities: A Grass-Roots Guide to Rebuilding Urban America. Holt Reinhart and Winston, New York, New York.

Citizens Planning and Housing Association of Baltimore. 1982. Neighborhood Self-Help Handbook. Citizens Planning and Housing Association of Baltimore, Maryland. Also available from Volunteer Readership, 1111 N. 19th Street, Arlington, Virginia.

Dermer, J. 1982. New Ways to Succeed With Foundations: A Guide to the Reagan Years. Public Service Materials Center, Hartsdale, New York.

Energy Conservation Coalition. 1984. Energy Conservation and Existing Rental Housing. Energy Conservation Coalition, Washington, D.C.

Environmental Policy Institute. 1983. An Energy Efficiency Strategy for Multifamily Housing (A Denonstration Project). Environmental Policy Institute for the Department of Housing and Community Development, Washington, D.C.

Geller, E. (ed.). 1979. Saving American Cities. The H.W. Wilson Company, New York, New York.

Government Printing Office. Affordable Manufactured Housing Through Energy Conservation: A Guide to Designing and Constructing Energy Efficient Homes. Washington, D.C. 
Gulley, H. E. 1968. Discussion, Conference, and Group Process, 2nd ed. Holt, Rinehart, and Winston, New York, New York.

Huenfeld, J, 1970. The Community Activist's Handbook: A Guide to Organizing, Financing, and Publicizing Community Campaigns. Beacon Press, Boston, Massachusetts.

Institute for Man and Environment. Energy Conservation in Mobile Homes. Plattsburg State University, Plattsburg, New York.

King, C. 1985. Working With People in Community Action. Associated Press, New York, New York.

Kotler, P. 1982. Marketing for Non-Profit Organizations. Prentice-Hall, Inc., Englewood Cliffs, New Jersey.

Lansley, J. 1973. Community Organizations and Local Government Reform. Community Councils Development Group, Liverpool, England.

Lawton, M. P., et al. 1976. Community Planning for an Aging Society: Designing Services and Facilities. Dowden, Hutchinson, and Ross, New York, New York.

Liebert, E., and B. Sheldon, 1972. Handbook of Special Events for Non-Profit Organizations. Associated Press, New York, New York.

Monroe, D. and K. Monroe. 1962. How to Succeed in Community Service. J. B. Lippincott Company, Philadelphia, Pennsylvania.

Naparstek, A. J., D. E. Biegel and H. R. Spiro, 1982. Neighborhood Networks for Humane Mental Health Care. Plenum Press, New York, New York.

National Bureau of Standards. 1980. Air Leakage Characteristics and Weatherization for Low-Income Housing. Center for Building Technology, National Bureau of Standards, Washington, D.C.

National Bureau of Standards. 1980. Optimizing Weatherization Investments in Low-Income Housing: Economic Guidelines and Forecasts. Center for Building Technology, National Bureau of Standards, Washington, D.C.

National Bureau of Standards. 1982. Technique for Tracking the Effect of Weatherization on Low-Income Housing. Center for Building Technology, National Bureau of Standards, Washington, D.C.

National Council of Senior Citizens. 1981. Energy and the Elderly Sourcebook. National Council of Senior Citizens, Washington, D.C.

Residential Energy Conservation Consulting Group. Mobile Homes: Characteristics, Retrofit Possibilities. Residential Energy Conservation Consulting Group, Fairchild, Wisconsin. 
Strauss, B. and M. E. Stowe. 1974. How to Get Things Changed: A Handbook for Tackling Community Problems. Doubleday, New York, New York.

Taber, M. C., et al. 1972. Handbook for Community Professionals: An Approach for Planning and Action. Charles C. Thomas, Springfield, Illinois.

Tobin, D. and H. Ware. 1983. The Barter Network Handbook: Building Community Through Organized Trade. Ava Tlable from Volunteer Readership, 1111 N. 19th Street, Arlington, Virginia.

Trapp, S. 1976. A Challenge for Change: Selected Essays on Community Organizing, Leadership Development, and Citizen Participation. National Training and Information Center, Chicago, Illinois.

Trapp, S. 1976. Dynamics of Organizing. National Training and Information Center, Chicago, Illinois.

Trecher, H. B., and A. R. Trecher, 1979. Working With Groups Committees and Communities. Association Press, Follett Publishing Company, Chicago, Illinois.

U.S. Department of Energy. 1980. Energy Consumption by Low-Income Households - A Review of Studies, Surveys and Models. U. S. Department of Energy, Washington, D.C.

Urban Systems Research \& Engineering, Inc. Investigation of Multifamily Issues. Weatherization Assistance Program, U. S. Department of Energy Progran Office, Massachusetts.

Warren, R., and D. Warren. 1977. Neighborhood Organizers Handbook. University of Notre Dame Press, Notre Dame, Indiana.

\section{FUND RAISING - BY COMMUNITY GROUPS OR OTHER FOUNDATIONS}

Abramson, A. J., and L. M. Salamon, 1982. The Federal Budget and the Nonprofit Sector. The Urban Institute, Baltimore, Maryland.

Alter, J. October 1976. "101 Surefire Fund-Raising Ideas." Family Circle. Available from the Reprint Department, Family Circle, 488 Madison Avenue, New York, New York 10022.

Broce, T. E. 1979. Fund Raising; The Guide to Raising Money from Private Sources. University of Oklahoma Press, Norman, Oxlahoma.

Brownrigg, W. G. 1982. Effective Corporate Fundraising. American Council for the Arts, New York, New York.

Dermer, J. 1975. How to Write Successful Foundation Presentations. Available from the Public Service Materials Center, New York, New York. 
Dermer, J. 1975. The New How to Raise Funds from Foundations. Available from the Public Service Materjals Center, New York, New York.

Dermer, J. 1977. Where America's Large Foundations Make Their Grants. Available from the Public Service Materials Center, New York, New York.

Dermer, J., and S. Wertheimer. 1982. The Complete Guide to Corporate Fund Raising. Available from the Public Service Materials Center, Hartsdale, New York.

Des Marais, P. How to Get Government Grants. Available from the Public Service Materials Center, New York, New York.

Des Marais, P. How to Get Your Fair Share of Foundation Grants. Available from the Public Service Materials Center, New York, New York.

Des Marias, P. The 1976-1977 Survey of Grant-Making Foundations. Available from the Public Service Materials Center, New York, New York.

Drotning, P. T. 500 Ways for Small Charities to Raise Money. Available from the Public Service Materials Center, Hartsdale, New York.

Duncan, W. A. 1982. Looking at Income Generating Business for Small Nonprofit Organizations. Mountain Association for Community Economic Development, Berea, Kentucky.

Fitzsimmons, J. D., J. A. Nutter and K. A. Gilder. 1975. Housing Rehabilitation Loan Programs in Minnesota. Center for Urban and Regional Affairs, 311 Walter Library, University of Minnesota, Minneapolis, Minnesota.

Flanagan, J. 1977. The Grass Roots Fundraising Book: How to Raise Money in Your Community. Swallow Press, Chicago, Illinois. Available from The Youth Project, 1000 Wisconsin Ave., N.W., Washington, D.C. 20007.

Golden, H. 1976. The Grantseekers: The Foundation Fund Raising Manual. Oceana Publications, Dobbs Ferry, New York.

Gressel, D. 1976. Financing Techniques for Local Rehabilitation Programs. National Association of Housing and Redevelopment Officials, Washington, $0 . C$.

Grub, D. L., and D. R. Zwick. 1976. Fundraising in the Public Interest. Fundraising in the Public Interest, P.0. Box 19367, Washington, D.C. 20036.

Gurin, M. G. 1981. What Volunteers Should Know For Successful Fundraising. Available from Volunteer Readership, 1111 N. 19th Street, Arlington, Virginia.

Guzman, C. 1982. Semillas de Prosperidad or How to Cultivate Resources from the Private Sector. Neighborhood Housing Services of Albuquerque, Albuquerque, New Mexico. 
Haywood, A. M. (compiler). 1982. The Resource Directory for Funding and Managing Nonprofit Organizations. Edna McConnell Clark Foundation, New York, New York.

Hillman, H. 1980. The Art of Winning Corporate Grants. Vanguard Press, New York, New York.

Hummel, J. 1980. Starting and Running a Nonprofit Organization. University of Minnesota Press, Minneapolis, Minnesota.

Humphries, H. R. 1972. Fund Raising for Small Charities and Organizations. David \& Charles, Trafalgar Square, North Ponfret, Vermont.

Johnsen, R., D. Tobin and J. Bond. 1982. Organizing for Local Fundraising: Self-Sufficiency for the $80 \mathrm{~s}$. Avallable from Volunteer Readership, $1111 \mathrm{~N}$. 19th Street, Arlington, Virginia.

Lucas, R. A. and T. R. Harvey. "Successful Strategies for Institutionalizing Grants." Grants Magazine.

Marino, D. R., L. B. Rosser and A. R. Rozran. 1979. The Planner's Role in Facilitating Private Sector Reinvestment. PAS Report No. 340, American Planning Association, Chicago, Illinois.

Marquis Academic Media. 1978. Grantsmanship: Money and How to Get It. 2nd edition, Chicago, Illinois.

Miller, T., and G. R. Orser. You Don't Know What You Got Until You Lose It. Available from The Support Center, 1709 New Hampshire Avenue, NW, Washington, D.C.

Mirkin, H. R. 1978. The Complete Fund Raising Guide. Available from the Public Service Materials Center, New York, New York.

Non-Profit Report. Non-Profit Report: The Philanthropy Monthly. Danbury, Connecticut.

Pendleton, N. 1981. Fund Raising: A Guide for Non-Profit Organizations. Prentice-Hall, Inc., Englewood Cliffs, New Jersey.

Petersen, S. 1979. Successful Community Fund Raising: A How-to Manual. Available from Volunteer Readership, 1111 N. 19th Street, Arlington, Virginia.

Peterson, E. B. 1974. Spend Less, Rajse More. A Cost-Conscious Look at Direct Mail Fund Raising. Direct Mail Fundraisers Association, 810 Seventh Ave., New York, New York 10019.

Public Management Institute. 1981. How to Get Corporate Grants. Public Management Institute, San Francisco, California.

Public Service Materials Center. 1973. How to Get Your Fair Share of Foundation Grants. Public Service Materials Center, New York, New York. 
Robertson, J., and J. Lewallen. 1975. The Grassroots Primer. Sierra Club Books, San Francisco, California.

Seltzer, M. and T. Sweeney. 1981. Survival Planning for the 80's: Fund Raising Strategies for Grassroots Organizations. Community Jobs, Washington, D.C.

Sheridan, P. G. 1968. Fund Raising for the Small Organization. M. Evans \& Company, Inc., New York, New York.

The Corporate Fund Raising Directory (1983-84 Edition). Available from the Public Service Materials Center, Hartsdale, New York.

The Fund Raising Institute. Bequest Program Handbook. The Fund Raising Institute, Box 122, Plymouth Meeting, Pennsylvania.

The Fund Raising Institute. Complete Handbook for Fund Raisers. The Fund Raising Institute, Box 122, Plymouth Meeting, Pennsylvania.

The Fund Raising Institute. Foundations Portfolio. The Fund Raising Institute, Box 122, Plymouth Meeting, Pennsylvania.

The Fund Raising Institute. Fund Raising Letter Collection. The Fund Raising Institute, Box 122, Plymouth Meeting, Pennsylvania.

The Fund Raising Institute. Publicity Portfolio. The Fund Raising Institute, Box 122, Plymouth Meeting, Pennsylvania.

The Regional Young Adult Project. 1981. The Bread Game: The Realities of Foundation Fundraising. Available from Volunteer Readership, 1111 N. 19th Street, Arlington, Virginia.

Western States Shelter Network. 1982. Dollars and Sense: A Community Fund Raising Manual for Women's Shel ters and Other Non-Profit Organizations. Western States Shelter Network, San Francisco, California.

White, V. P. 1979. Grants: How to Find Out About Them and what to do Next. Plenum Press, New York, New York.

\section{VOLUNTEERS - RECRUITING, TRAINING, AND MANAGING}

8rown, K. M. 1982. Keys to Making A Volunteer Program Work: A Guide for Organizations That Use Volunteers. Available from Volunteer Readership, 1111 N. 19th Street, Arlington, Virginia.

Coit, E. 1964. Volunteers Can Make the Difference. Conmittee of Correspondence, New York, New York.

Council of National Organizations. 1963. Probing Volunteer-Staff Relations. Association Press, New York, New York. 
Flanagan, J. 1981. The Successful Volunteer Organization: Getting Started and Getting Results in Nonprofit, Charitable, Grass Roots, and Community Groups. Available from Volunteer Readership, 1111 N. 19th Street, Arlington, Virginia.

Haines, M. 1977. Volunteers: How To Find Them, How To Keep Them. Available from Volunteer Readership, 1111 N. 19th Street, Arlington, Virginia.

Human Resources Network. 1976. The Handbook of Corporate Social Responsibility: Profiles of Involvement. 2010 Chancellor St., Philadelphia, Pennsylvania 19103.

Klein, A. F. 1972. Effective Groupwork: An Introduction to Principle and Method. Association Press, New York, New York.

KTein, D. J. 1975. Developing Human Services in New Communities. Behavorial Publications, New York, New York.

Koch, F. 1979. The New Corporate Philanthropy. Plenum Press, New York, New York.

MacBride, M. 1979. Step By Step: Management of the Volunteer Program in Agencies. Available from Volunteer Readership, 1111 N. 19th Street, Arlington, Virginia.

Maves, P. B. 1981. Older Volunteers in Church and Community: A Manual for Ministry. Available from Volunteer Readership, 1111 N. 19th Street, Arlington, Virginia.

National Center for Community Action. 1975. Human Work for Human Needs: A Catalog of Community Action Programs. National Center for Cominunity Action, 1711 Connecticut Ave., N.W., Washington, D.C.

National Center for Voluntary Action. 1975. Recruiting Volunteers: Views, Techniques and Comments. National Center for Voluntary Action, Massachusetts Ave., N.W., Washington, D.C. 20036.

Naylor, H. H. 1973. Volunteers Today: Finding. Training and Working with Them. Dryden Assoctates, Dryden, New York.

0'Connel1, B. 1983. America's Voluntary Sp1rit: A Book of Readings. Available from Volunteer Readership, 1111 N. 19th Street, Arlington, Virginia.

Park, J. M. 1983. Meaning Well is Not Enough: Perspectives on Volunteering. Available from Volunteer Readership, 1111 N. 19th Street, Arlington, Virginia.

Porter, R. A. (ed). 1983. Guide to Corporate Giving 3. American Council for the Arts, New York, New York.

Reisman, F., and A. Pearl. 1965. New Careers for the Poor. The NonProfessional in Human Service. Free Press, Giencoe, Illinois. 
Vineyard, S. 1981. Beyond Banquets, Plaques and Pins: Creative Ways to Recognize Volunteers and Staff. Available from Volunteer Readership, 1111 N. 19th Street, Arlington, Virginia.

Vineyard, S. 1984. Marketing Magic for Volunteer Programs. Available from Volunteer Readership, 1111 N. 19th Street, Arlington, Virginia.

VOLUNTEER. Volunteer Readership, 1978-79: Fifty-Three Books for Better Volunteering. Division of National Information Center on Volunteerism and the National Center for Voluntary Action. P.0. Box 1807, Boulder, Colorado.

VOLUNTEER. 1985. Directory of Volunteer Centers. Available from Volunteer Readership, 1111 N. 19th Street, Arlington, Virginia.

Warren, D. I. 1981. Helping Networks: How People Cope with Problems in the Urban Community. University of Notre Dame Press, Notre Dame, Indiana.

\section{PROPOSAL WRITING - CORPORATE AND FOUNDATION}

Biegel, L. and A. Lubin. 1975. Mediability: A Guide for Nonprofits. Taft Publications, Inc., Washington, D.C.

Brigham, N. 1975. How to Do Leaflets, Newsletters, and Newspapers. Boston Community School. Available from New England Free Press, Somervîlle, Massachusetts.

Dermer, J. (ed.). America's Most Successful Fund Raising Letters. Avallable from the Public Service Materials Center, Hartsdale, New York.

Gordon, R. 1978. We Interrupt This Program...A Citizen's Guide to Using the Media for Social Change. Available from Volunteer Readership, 1111 N. 19th Street, Arlington, Virginia.

Hal1, M. 1977. Developing Skills in Proposal Writing. Continuing Education Publications, Portland, Oregon.

Lee, L. 1981. The Grants Game: How to Get Free Money. Harbor Publishing, San Francisco, California.

Lewis, M. 0. (ed.) 1979. The Foundation Directory. The Foundation Center, New York, New York.

Mayer, R. A. July 1972. "What Will a Foundation Look for When You Subrit a Grant Proposal?" Adapted from an article in Library Journal.

Mitiguy, N. The Rich Get Richer and the Poor Write Proposals. Available from The citizen Involvement Traíning Project, University of Massachusetts, 138 Hasbrouck, Amherst, Massachusetts. 
National Association of Broadcasters. 1974. If You Want Air Time. National Association of Broadcasters, $1771 \mathrm{~N}$ St., N.W., Washington, D.C. 20036.

Shapek, R. A. March 1984. "Do's and Dont's in Proposal Writing: How to Increase Your Probability of Obtaining Federal Funding." Grants Magazine. $7(1): 51-58$.

Sinclair, J. P. 1982. How To Write Successful Corporate Appeals - With Full Examples. Public Service Materials Center, Hartsdale, New York.

Somerville, B. Jan./Feb. 1982. "Where Proposals Fail: A Foundation Executive's Basic List of What to Do and Not Do When Requesting Funding." The Grantsmanship Center News. The Grantsmanship Center, Los Angeles, California.

White, V. P. (ed). 1983. Grant Proposals That Succeeded. Plenum Press, New York, New York.

Williams, M. J. 1981. Foundation Primer. 4th edition, Fund-Raising Institute, Ambler, Pennsylvania.

5. SOURCEBOOKS - LISTS OF ORGANIZATIONS, GROUPS, ETC.

Foundations That Send Their Annual Report. Available from the Public Service Materials Center, Hartsdale, New York.

Lewis, M. 0. (ed). 1979. The Foundation Directory. Seventh Edition, The Foundation Center, New York, New York.

Standard and Poor's Register of Corporations, Directors, and Executives. 3 Volumes. Annual. Standard and Poor's, 25 Broadway, New York, New York.

Standard and Poor's Register--Geographical Index. Annual. 25 Broadway, New York, New York.

The Council on Foundations. Foundation News. Council on Foundations, Inc., 1828 L Street, N. W., Washington, DC 20036.

The Foundation Center. Foundation Grants Index Bimonthly. The Foundation Center, 888 Seventh Avenue, New York, New York.

The Foundation Center. 1981. Source Book Profiles. The Foundation Center, 888 Seventh Avenue, New York, New York.

The Foundation Center. 1981. The Foundation Directory, 9th ed. The Foundation Center, 888 Seventh Avenue, New York, New York 10106.

The Foundation Center. 1984. Foundation Directory Supplement. The Foundation Center, 888 Seventh Avenue, New York, New York. 
The Foundation Center. 1984. Foundation Grants to Individuals, 4th ed. The Foundation Center, 888 Seventh Avenue, New York, New York.

The Foundation Center. 1984. The Foundation Grants Index: 13th ed. The Foundation Center, 888 Seventh Avenue, New York, New York.

The Foundation Center. 1984. The National Data Book, 8th ed. The Foundation Center, 888 Seventh Avenue, New York, New York.

The Gannett Foundation and the Foundation for American Communications. 1981. The Media Resource Guide: Who, what, When, where, Why, How to Tell Your Story. Available from Volunteer Readership, 1111 N. 19th Street, Arlington, Virginia.

The Grantsmanship Center. Grantsmanship Center News. The Grantsmanship Center, 1031 S. Grand Avenue, Los Angeles, California 90015.

U.S. Department of the Treasury, Internal Revenue Service. Revised to October 31, 1983. Cumulative List of Organizations. Superintendent of Documents, Washington, D.C. Available from the Government Printing Office, Washington, D.C.

VOLUNTEER. 1985. Report of Non-Cash Contributions. Available from Volunteer Readership, 1111 N. ligth Street, Arlington, Virginia.

Where America's Large Foundations Make Their Grants. (Fourth Edition). Available from the Public Service Materials Center, Hartsdale, New York. 
APPENDIX $\mathrm{C}$

STATE WEATHERIZATION OFFICES 


\section{STATE WEATHERIZATION OFFICES}

Alabama Department of Economic and Community Affairs

P.0. Box 2939

Montgomery, Alabama 36105-0939

Contact: Coreen Wontowski

(205) 284-8946

Alaska Division of Community Affairs Weatherization Section

949 E. 36th Avenue, Suite 403

Anchorage, Alaska 99508

Contact: John Munson

(907) 563-1955

Arizona Energy office

1700 W. Washington, 5th Floor

Phoenix, Arizona 85007

Contact: Russel Clark

(602) 255-3303

Arkansas Department of Human Services

P. 0. Box 751

Little Rock, Arkansas 72203

Contact: Gene Martin

(501) $370-2702$

California Office of Economic Opportunity

1600 9th Street, Room 340

Sacramento, California 95814

Contact: Dennis Miller

(916) $324-2940$

Colorado Division of Housing

1313 Sheman, Room 419

Denver, Colorado 80203

Contact: Susan Madian

(303) 866-2033

Connecticut, Under Secretary of Energy 80 Washington Street

Hartford, Connecticut 06016

Contact: John Ruskes

(203) $566-2800$
Delaware Department of Community Services

Division of Community Affairs

820 North French Street, 4th floor

Wilmington, Delaware 19801

Contact: Ken Davis

(302) 571-3491

Florida Department of Community Affairs 2571 Executive Center Circle East

Tallahassee, Florida Contact: Ray Smith

(904) 487-3481

Georgia Office of Energy Resources

270 washington, SW, Room 615

Atlanta, Georgia 30334

Contact: Kris Allison

(404) 656-5176

Hawaii State Energy office

Department of Planning and Economic Development

335 Merchant Street, Room 109

Honolulu, Hawaii 96804

Idaho Division of Energy Resources

Department of Health and Welfare

450 West State Street

Boise, Idaho 83720

Contact: Pete Gonzales

(208) $334-3815$

Illinois Department of Commerce and Community Affairs

Office of Human Services

620 East Adams

Springfield, Illinois 62701

Contact: Wayne Curtis

(217) 785-6203

Indiana Department on Aging and Community Services

Division of Community Services for Low Income

One North Capitol, Commerce Center

Indianapoi is, Indiana 46204

Contact: Sabrina Edwards

(317) 232-7006 
Iowa Energy Power Council Energy Assistance Division

Weatherization Program

Lucas Building, Room 2001

State office Complex

Des Moines, Iowa 50319

Contact: Walter Pickett

(515) 281-4204

Kansas Department of Social and Rehabilitation Services

c/o Kansas Corporation Commission

State Office Bldg., 4th Floor

Topeka, Kansas 66612

Contact: Joe Konrad

(913) 296-5460

Kentucky Energy Cabinet

P.0. Box 1188

3572 Ironworks Road

Lexington, Kentucky 40578

Contact: Carol Wallace

(606) 252-5535

Louisiana Department of Urban \& Community Affairs

Office of Community Services

P.0. Box 94455

Baton Rouge, Louisiana 70804

Contact: J. W. Vaughn

(504) 925-7948

Maine Office of Energy Resources

$301 \mathrm{~W}$. Preston St., $\# 53$ State House Station

Augusta, Maine 04333

Contact: Herb Sperry

(207) 289-3811

Maryland Weatherization Office

1123 North Eutaw Street

Baltimore, Maryland 21201

(301) $383-3266$

Massachusetts Office of Energy Conservation

100 Cambridge St.

Boston, Massachusetts 02202

Contact: William Concannon

(617) $727-6964$
Michigan Department of Social Services

Office of Income Assistance

300 South Capitol

Lansing, Michigan 48909

Contact: Linda Crandall

(517) $373-2004$

Minnesota Department of Jobs and

Training

690 American Center Building

St. Paul, Minnesota

Contact: Mark Kaszynski

(612) 297-2590

Mississippi Office of Energy and Community Services

Low-Income Weatherization Assistance Program

301 West Pearl Street

Jackson, Mississippi 39203-3094

Contact: Eddy Ramsey

(601) $949-2038$

Missouri Department of Natural Resources

Division of Energy, Weatherization Section

P.0. Box 176

Jefferson City, Missouri 65102

Contact: Eldon Hattervig

Montana State Department of Social and Rehabilitation Services

P.O. Box 4210

Helena, Montana 59604

Contact: Charles Poole

(404) 444-4137

Nebraska Energy Office

State Capitol Building, 9th Floor

Lincoln, Nebraska 68509

Contact: Pete Davis

(402) $471-2867$

Nevada State Office of Community Service 1100 E. William St. Suite 117

Carson City, Nevada 89710

Contact: Craig Davis

(702) $885-4420$ 
New Hampshire Governor's Energy office 11 Depot St., 3rd Floor

Concord, New Hampshire 0330

Contact: Rick Haines

(603) 271-2611

New Jersey Department of Community Affairs

Office of Low-Income Energy Conservation

363 West State Street

Trenton, New Jersey 08625

Contact: Grey Adkins

(609) 292-6140

New Mexico Department of Energy and Minerals

Conservation and Management Division

525 Camino de los Marquez

Santa Fe, New Mexico 87501

Contact: Anita Heisenburg

(505) 827-5922

New York State Energy office

Two Rockfeller Plaza

Albany, New York 12223

Contact: Mr. Petty

(212) 587-5724

North Carolina Department of Commerce Energy Division

P.0. Box 25249

Raleigh, North Carolina 27611

Contact: Walter Bray

(919) $733-2230$

North Dakota Weatherization Program office of Intergovernmental Assistance State Capitol Building, 4th Floor

Bismark, North Dakota 58505

Contact: Kim Nesbig

Ohio Office of Energy Conservation

Ohio Dept. of Development

P. 0. Box 1001

Columbus, Ohio 43266-0101

Contact: Stjepan V1anovich

(614) $466-2480$
OkTahoma Energy Conservation and Consumer Department

Oklahoma Corporation Comission

17 NE 28th Street

Oklahoma City, Oklahoma 73105

Contact: Jennifer Flack

(405) $521-3941$

Oregon Department of Energy

102 Labor and Industries Building

Salem, Oregon 97310

Contact: Gary Curtis

(503) 378-4040

Pennsylvania Department of Community Affairs

Bureau of Human Resources

RM 362 Forum Bldg.

Harrisburg, Pennsylvania 17120

Contact: Dennis Darling

(717) 7B7-7301

Rhode Island Governor's Energy office 275 Westmenster Mall

Providence, Rhode Island 02903

Contact: Al Scappaticcí

(401) $277-6920$

South Carolina, Office of the Governor

Division of Economic Opportunity

1712 Hampton Street

Columbia, South Carolina 29201

Contact: Grey Adams

(803) $758-3191$

South Dakota, Energy Assistance Office 217 1/2 W. Missouri

State Capitol

Pierre, South Dakota 57501

Contact: Cindy Loen

(605) $773-3766$

Tennessee Department of Human Services 111 7th Avenue North

Nashville, Tennessee 37203

Contact: David Farmer

(615) 741-5924 
Texas Energy Efficiency Division, Public Utilities Conmission of Texas 7800 Shoal Creek Boulevard, Suite $400 \mathrm{~N}$ Austin, Texas 78757

Contact: Chris Reitsch (512) 458-0315

Utah State Energy Office $355 \mathrm{~W}$. North Temple Third Triad Center, Suite 450

Salt Lake City, Utah 84180-1204

Contact: Mike Glen or Mike Johnson (801) $538-5428$

Vermont State Economic Opportunity Office 103 S. Main Waterbury, Vermont 05676

Contact: Marcel Rcheleau (802) $241-2450$

Virginia Department of Mines, Minerals and Energy

2201 West Broad Street

Richmond, Virginia 23220

Contact: Jennifer Snead

(804) 257-0330
Washington Department of Commerce 400 East Union, 1st Floor

Olympia, Washington 98504

Contact: Claire Hopkins

(206) 753-4106

West Virginia Governor's Office of

Community and Industrial Development

State Capitol Complex Bldg. 6, RM B553

Charleston, West Virginia 25305

Contact: Dan Cottrill

(304) $348-4010$

Wisconsin Department of Health and Social Services

P.0. Box 7868

Madison, Wisconsin 53707

Contact: Peter Polish

(608) 266-1049

Wyoming Energy Conservation Office Barrett Building, 3rd Floor 2301 Central Avenue Cheyenne, Wyoming 82002 (307) 777-7131 


\section{DISTRIBUTION}

No. of

Copies

OFFSITE

5 S. Heard

U.S. Department of Energy

Forrestal Building, 6A-087

Mai1 Stop CE-221

1000 Independence Ave., S.W. Washington, DC 20585

R. Brancato

U.S. Department of Energy

Forrestal Building, 6A-087

Mail Stop CE-221

1000 Independence Ave., S.W. Washington, DC 20585

N. E. Tate

U.S. Department of Energy

Forrestal Building, 6A-087

Mail Stop CE-221

1000 Independence Ave., S.W.

Washington, DC 20585

5 DOE Technical Information

Center

15 J. L. Chadwick

Department of Community Development

State of Washington

9th and Columbia Building M5-GH51

Olympia, WA 98504

5 D. Chaliman

Kentucky Energy Cabinet

P.0. Box $1188 \mathrm{~A}$

Lexington, KY 40578

5 H. Erikson

Florida Governor's Energy Office

301 Bryant Boulevard

Tallahassee, FL 32301
No. of

Copies

50 . Heiserman, Director

Community Action Joint Venture Project

Armory Building (Neighborhood Development)

East First \& DesMoines Streets

DesMoines, IA 50307

5 G. Miller

Department of Commerce

State of $0 \mathrm{klahoma}$

4545 North Lincoln Boulevard Suite 285

Ok lahoma City, OK 73105

B. Arganbright, Associate Director

AMOCO Foundation, Inc.

200 East Randolph

Chicago, IL 60601

G. L. Adams

Division of Economic Opportunity

1712 Hampt on Street

Columbia, SC 29201

T. Amo

Arkansas/Louisiana Gas Company

P.0. Box 751

Little Rock, AR 72203

R. Aull

Chief of Energy Weatherization Program

City of Baltimore

920 East 25th Street

Baltimore, MD 21218

H. Berkman, Program Manager

Energy Resource Center

427 St. Clair Avenue

St. Pau1, MN 55102 
No. of

Copies

D. J. Bonnetti, Executive
Director
Dickinson-Iron County CAA
Community Service Center
107 4th Street - P.0. Box 549
Iron River, MI 49935
J. Brownback, Executive
Director
Energy Efficient Building
Association
P.0. Box 1115
Pine Island, MN 55963

R. Chapman, Executive Director

Two Rivers Regional Council

Franklin Square

4 th and State Streets

Quincy, IL 62301

D. Collins

Planner/Evaluator

Human Resource Department

City of Rockford

1005 South Court

Rockford, IL 61102

G. Collver, Weatherization

Director

P.0. Box 200908

Anchorage, AK 99520

B. Davis

Economic Opportunity Agency of Washington County

2325 North Gregg

Fayettville, AK 72703

P. Dreyfuss, Executive Director

The Metropolitan Energy Information System

3808 Paseo

Kansas City, M0 64109
No. of

Copies

L. J. Flanagan

Executive Director

Wayne-Metropolitan Community Service Agency

3715 lest Jefferson

Ecorse, MI 48229

M. Foster

Community Action of Northeast Indiana

1120 South Barr

P.0. Box 10704

Ft. Wayne, IN 46802

A. Goldberg

Tuscon Urban League

2305 South Park

Tuscon, AZ 85713

J. joodrich

Project Home

214 South Baldwin

Madison, WI 53704

G. Hawkins, Program Manager

Potomac Electric Power Co.

1900 Pennsylvania Avenue

Northwest, Room 528

Washington, DC 20068

C. Hostick, Executive Director

North American Indian Cultural Centers

1159 Lakeshore Boulevard

Akron, $\mathrm{OH} 44301$

J. Kolva, Program Director

Weatherize Boston

City of Boston Mayor's Office

One City Hall Plaza

Boston, MA 02201 
No. of

Copies

R. Koopmeiners

Energy Conservation Consultant

Peoples Natural Gas

1414 West Broadway

Council Bluffs, IA 51501

M. Leftwich

Six Points Evaluation and

Training, Inc.

125 West Virginia

P.0. Box 1002

Gunnison, C0 81230

S. McCauley, Energy Management Supervisor

Chugach Electric Association

P.0. Box 196300

Anchorage, AK 99519-6300

R. McIntire

Weatherization Program Director

120 Independence Avenue

Waterloo, IA 50703

C. C. Miller, Civic Affairs Representative

Baltimore Gas \& Electric Co. P.0. Box 1457

Baltimore, MD 21203

J. Mullendore, Supervisor Residential Activities

Potomac Edison Co.

Downsville Pike

Hagerstown, MD 21740

J. Perkins

Nashville Electric Service

1214 Church Street

Nashville, TN 37246

R. Picket, Energy Programs Manager

Interlocal CAP

Box 644

Newcastle, IN 47362
No. of

Copies

W. Pickett, Coordinator of Weatherization Programs

Iowa Energy Power Council

Energy Assistance Division

Capitol Complex

Des Moines, IA 50319

B. Poirier, Staff Engineer

Office of Energy Conservation

112 East 14th Avenue

Denver, C0 80203

H. Powel1, Executive Director Energy Assistance Foundation P.0. Box A 1749

Decatur, IL 62526

L. Rovenstine, Program Director

Centralia Area Energy Assistance Program

1606 East Second Street

Centralia, IL 62801

D. Seigler

Westside Energy Coop.

825 West 11 th

Denver, C0 80214

H. Sperry/D. Fishman

WHIP/WOW

Office of Energy Resources

State House Station $\$ 53$

Augusta, ME 04333

S. Strom

Operation Insulation

City of Minneapolis Energy Office

330 City Hall

Minneapolis, MN 55415

R. Widak, Executive Director Worcester Labor Coop. 205 Millbury Street

Worcester, MA 01610 
No. of

Copies

ONSITE

DOE Richland Operations Office

J. J. Sutey

22 Pacific Northwest Laboratory

R. C. Adams

C. Geffen

D. L. Brenchley

J. W. Callaway (3)

L. J. Davis

B. Garrett-Price

D. L. I vey (2)

A. D. Lee

V. E. Lee

S. A. Smith (2)

E. J. Westergard

Publishing Coordination (2) $\mathrm{MH}$

Technical Report Center (5) 